\title{
Reinis Balmaks
}

\section{CILVĒKA RESPIRATORĀ SINCITIĀLĀ VĪRUSA IZRAISĪTO DZIĻĀKO ELPCEĻU INFEKCIJU KLINNISKAIS UN MOLEKULĀRAIS RAKSTUROJUMS HOSPITALIZĒTIEM BËRNIEM LATVIJĀ}

Promocijas darbs medicīnas doktora zinātniskā grāda iegūšanai Specialitāte - pediatrija 


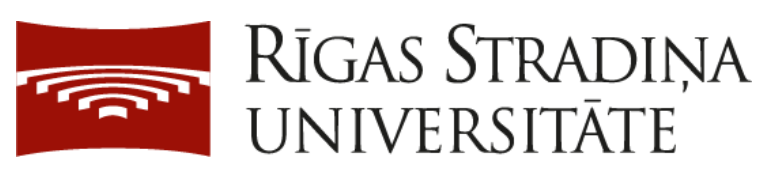

Reinis Balmaks

\section{CILVĒKA RESPIRATORĀ SINCITIĀLĀ VĪRUSA IZRAISĪTO DZIḶĀKO ELPCEĻU INFEKCIJU KLĪNISKAIS UN MOLEKULĀRAIS RAKSTUROJUMS HOSPITALIZĒTIEM BĒRNIEM LATVIJĀ}

Promocijas darbs

medicīnas doktora zinātniskā grāda iegūšanai

Specialitāte - pediatrija

Darba zinātniskie vadītāji:

Dr. habil. med., profesore Dace Gardovska

Dr. biol. Andris Kazāks 


\section{Finansējuma avoti}

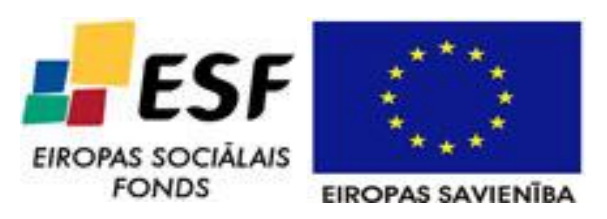

leguldījums tavā nākotnē!

1. Promocijas darbs izstrādāts ar ESF līdzfinansēta projekta „Atbalsts doktorantiem studiju programmas apguvei un zinātniskā grāda ieguvei Rīgas Stradiṇa universitātē”, vienošanās Nr. 2009/0147/1DP/1.1.2.1.2/09/IPIA/VIAA/009, atbalstu.

2. Latvijas Republikas Izglītības un zinātnes ministrijas Studiju un zinātņu administrācijas grants 09.1604, „Dzīves kvalitāti Latvijā būtiski ietekmējošo atsevišķ̧o mikroorganismu - Borrelia burgdorferi sensu lato kompleksa baktēriju, RSV un hMPV izraisīto slimību klīniskais, bioksīmiskais un molekulāri ǵenētiskais raksturojums, personificēta pieeja diagnostikai un ārstēšanai, slimības gaitas prognozēšana". 


\section{ANOTĀCIJA}

\section{Anotācija latviešu valodā}

Cilvēka respiratorais sincitiālais vīruss (HRSV) ir īpašs izaicinājums bērnu infekciju slimībās. Pirmkārt, tas ir visbiežākais dziḷāko elpcel̦u infekciju izraisītājs agrīna vecuma bērniem, kas šajā grupā ir vadošais mirstības un hospitalizācijas iemesls. Otrkārt, tam nav pieejama efektīva specifiskāa ārstēšana. Treškārt, lai arī efektīva un droša vakcīna ir globāla prioritāte, tās izstrāde kavējas I fāzes klīniskajos pētījumos. Viens no tās izveides apgrūtinājumiem - ātrā vīrusa mainība - tika analizēts šajā pētījumā.

Trīs secīgu sezonu laikā pētījumā tika prospektīvi iekļauti 207 stacionēti bērni ar dziḷāko elpceḷu infekciju. Lai diagnosticētu HRSV un izšķirtu tā galvenās grupas, HRSV-A un B, š̀ pētījuma nolūkiem tika izstrādāta uz polimerāzes ķēdes reakciju balstīta metode, ar kuru $88(42,5 \%)$ pētījuma pacientiem tika detektēta HRSV infekcija. HRSV epidemioloǵiskās aktivitātes periods ilga no 51. līdz 19. gada nedēḷai. Ikgadējo uzliesmojumu laikā HRSV izraisīja vairāk kā 90\% bronhiolītu un 50\% pneimoniju. Ar HRSV inficētie pacienti bija ievērojami jaunāki, un to vecums pārsvarā bija zem 6 mēnešiem. Ar molekulāro analīzi tika konstatēts, ka abu grupu vīrusi cirkulē paralēli, tomēr HRSV-A dominēja pirmajās divās sezonās, kurām sekoja HRSV-B dominanta sezona. Grupu ietvaros prevalēja viens genotips, NA1 (HRSV-A) un BA-IV (HRSV-B), kuri šajā laikā bija plaši izplatīti arī pasaulē. Statistiski ticamas klīniskās atšķirības starp dažādu grupu un genotipu izraisītajām infekcijām netika atrastas. 2012. gadā Latvijā tika konstatēts nesen atklātais HRSV-A genotips ON1, kuram raksturīgā 72 nukleotīdu duplikācija G gēnā tika izmantota, lai rekonstruētu tā globālo izplatību un populācijas dinamiku.

Šis ir pirmais HRSV molekulārās epidemioloğijas pētījums Latvijā un tam ir gan lokāla, gan globāla zinātniskā novitāte. Tas aktualizē precīzu HRSV sezonalitātes datu nepieciešamību Latvijā. Tika atklāti vairāki jauni HRSV celmi, kuru sekvences ir deponētas GenBank datu bāzē. Šis pētījums ir pirmais, kas izvirza genotipa ON1 migrēšanas hipotēzi un populācijas dinamikas aplēses. Iegūtie dati var tikt izmantoti optimālākai imūnprofilakses pielietošanai riska grupas zīdaiņiem Latvijā un globālo sabiedrības veselības stratēǵiju plānošanā. 


\section{Summary in English}

Human respiratory syncytial virus (HRSV) represents a particular challenge in pediatric infectious diseases. First, it is the most common etiologic agent of lower respiratory tract infections in infants and young children, which is the leading cause of hospitalization and mortality in this age group. Second, there is no effective specific treatment available. Third, although effective and safe vaccine is a global priority, its research is still in phase I clinical trials. One of the challenges in vaccine development, the high variability of the virus, was addressed in this study.

A total of 207 hospitalized children with lower respiratory tract infections were prospectively enrolled in the study over three consecutive seasons. For HRSV diagnosis and group, HRSV-A and B, differentiation a polymerase chain reaction based method was developed that tested positive $88(42.5 \%)$ of the patients. The seasonal activity lasted from weeks 51 to 19 . During the annual outbreaks, HRSV caused more than $90 \%$ of bronchiolitis and $50 \%$ of pneumonia. Children with HRSV lower respiratory tract infection were significantly younger than those with non-HRSV and were mostly less than 6-month-old. Molecular analysis revealed that the strains of both groups co-circulated, however HRSV-A viruses predominated for the first two consecutive seasons followed by an HRSV-B dominant season. Within the groups, viruses belonged to the worldwide dominant genotypes NA1 (HRSV-A) and BA-IV (HRSV-B). Clinical characteristics of infections caused by the different groups or genotypes were not statistically significant. In 2012, recently described HRSV-A genotype ON1 emerged in Latvia. Its characteristic 72nucleotide duplication in the $\mathrm{G}$ gene was exploited to reconstruct the global spread and population dynamics of this genotype.

This is the first molecular epidemiologic study of HRSV in Latvia and it has several important findings. It emphasizes the need for precise HRSV seasonality data. In this study several new HRSV strains were detected and deposited in GenBank database. This is also the first study suggesting a hypothesis of the global dissemination and population dynamics of the novel genotype ON1. The data presented here can be used to optimize timing of immunoprophylaxis in the high-risk infants in Latvia and to develop global public health interventions. 


\section{SATURS}

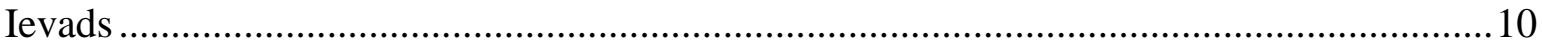

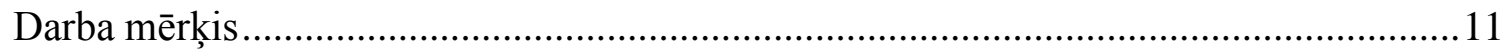

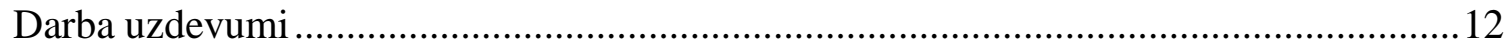

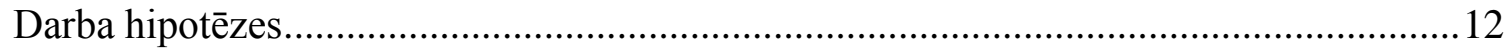

1. Literatūras apskats ......................................................................................13

1.1. Virālo dziḷāko elpceḷu infekciju slogs bērniem.....................................................13

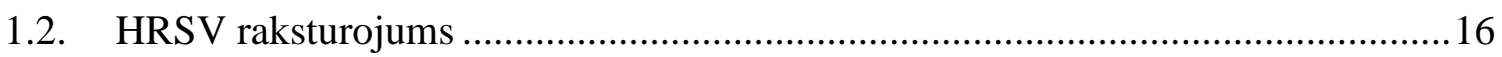

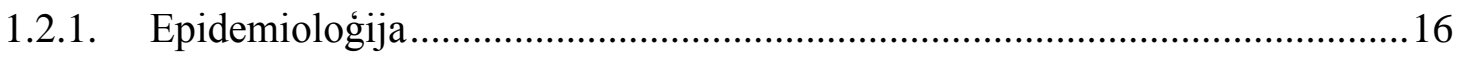

1.2.2. Virusoloǵiskais raksturojums ………………………....................................17

1.2.3. Klīniskās izpausmes...................................................................................19

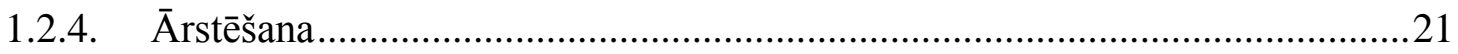

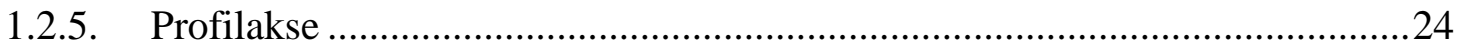

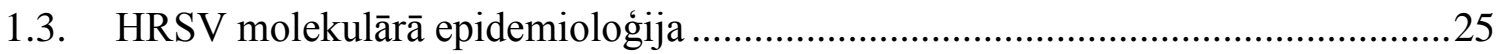

1.3.1. HRSV galvenās antigēnās grupas ..................................................................25

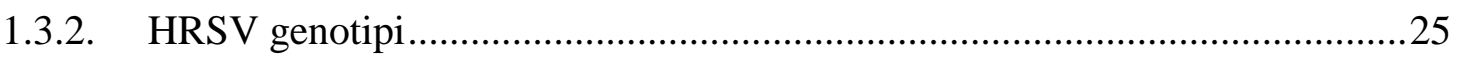

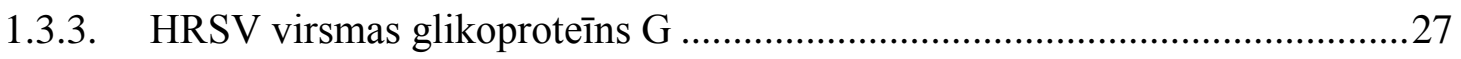

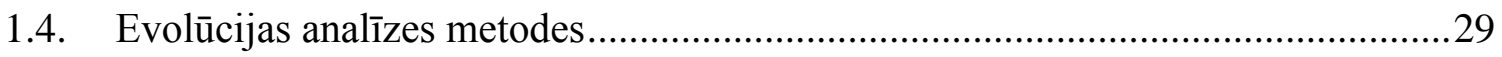

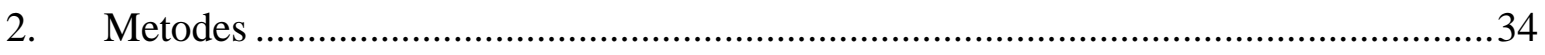

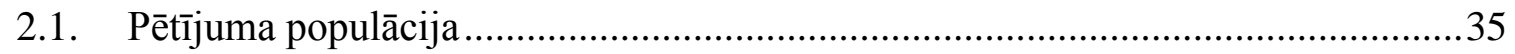

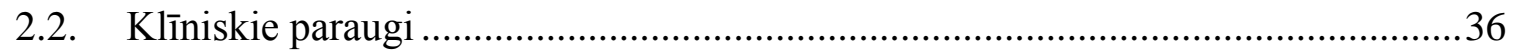

2.3. HRSV diagnostika, grupu diferencēšana, sekvenēšana ..........................................37

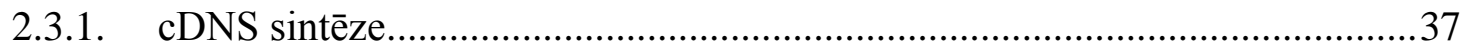

2.3.2. HRSV diagnostika un grupu diferencēšana ....................................................38

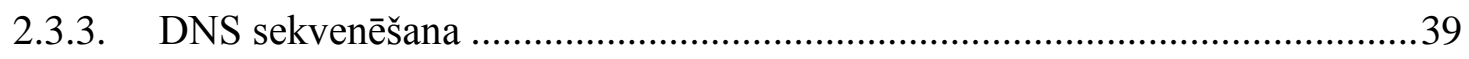


2.4. Filoǵenēzes un adaptīvās evolūcijas analīze

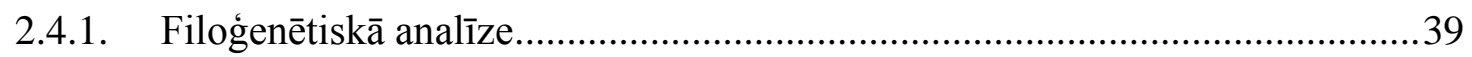

2.4.2. Glikozilācijas vietu prognozēšana ..................................................... 40

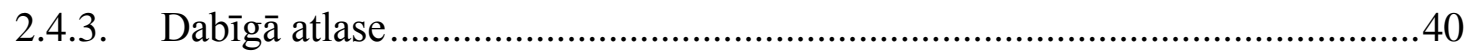

2.5. Evolūcijas ātrums, populācijas dinamika un filoǵgeogrāfiskā analīze ..................41

2.6. Datu statistiskā apstrāde ............................................................................42

2.6.1. HRSV sezonalitātes datu statistiskā apstrāde ........................................42

2.6.2. Klīnisko datu statistiskā apstrāde .........................................................43

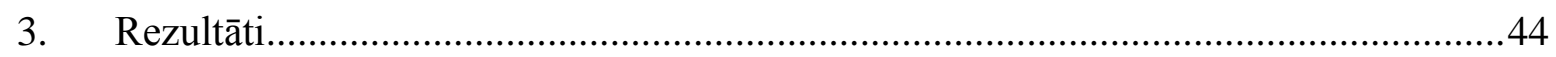

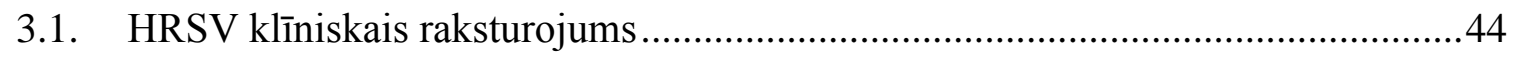

3.1.1. Pētījuma pamatgrupa .................................................................... 44

3.1.2. HRSV diagnostika un grupu diferencēšana ............................................44

3.1.3. HRSV sezonalitāte ............................................................................46

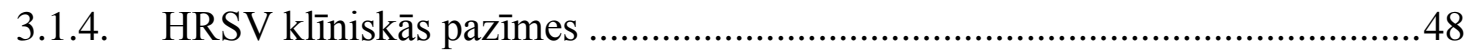

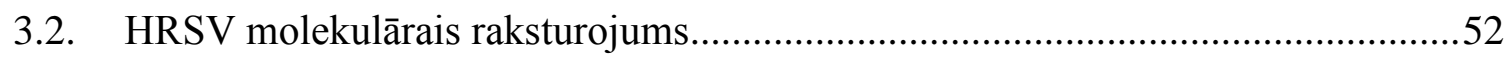

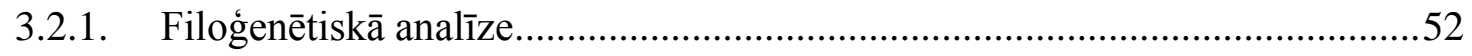

3.2.2. Genotipa NA1 molekulārais raksturojums .............................................57

3.2.3. Genotipa BA-IV molekulārais raksturojums ..........................................61

3.2.4. Genotipa ON1 globālā filodinamika un filoǵeogrāfija ..............................63

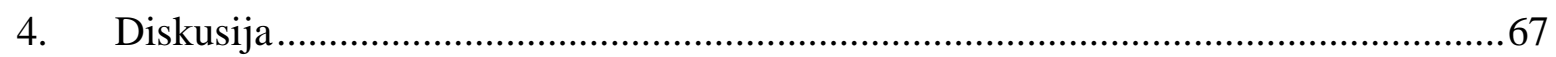

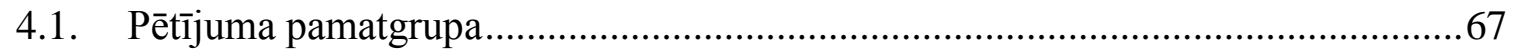

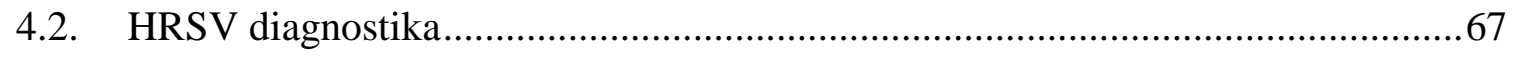

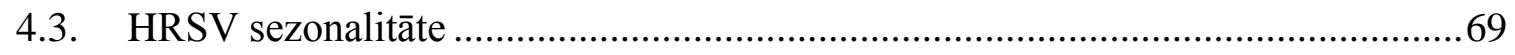

4.4. HRSV klīnisko pazīmju raksturojums ....................................................... 71

4.5. HRSV grupu un genotipu klīniskais raksturojums........................................73 


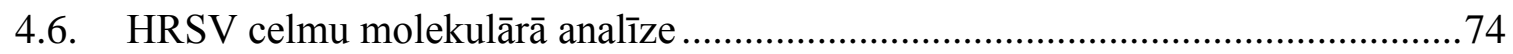

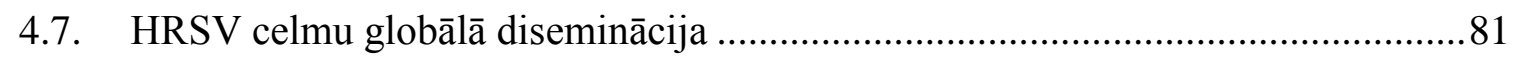

4.8. Pētījuma datu interpretācijas ierobežojumi .................................................... 85

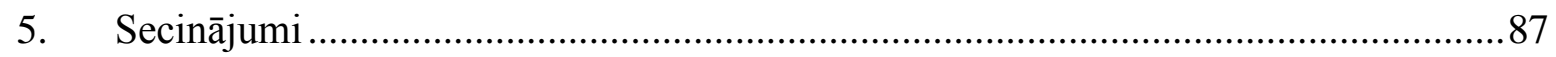

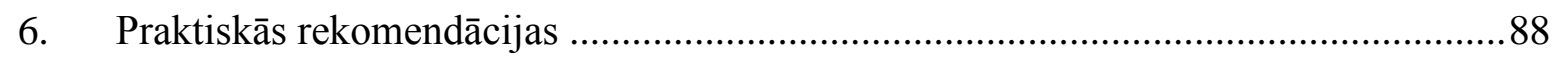

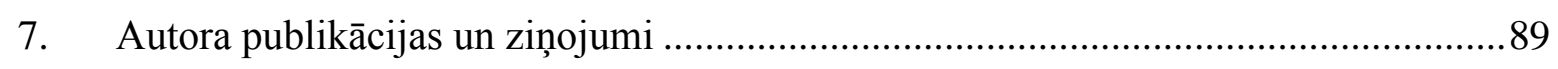

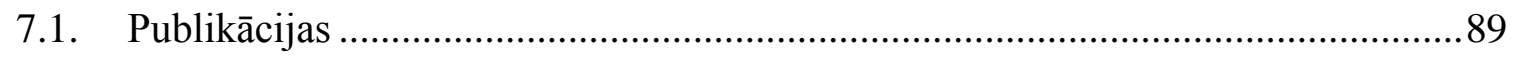

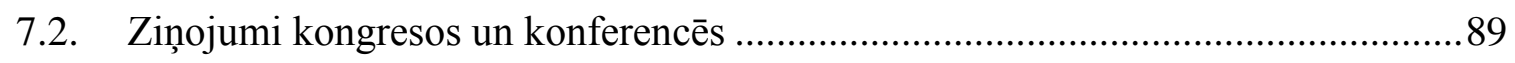

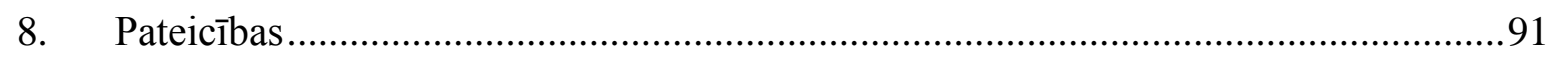

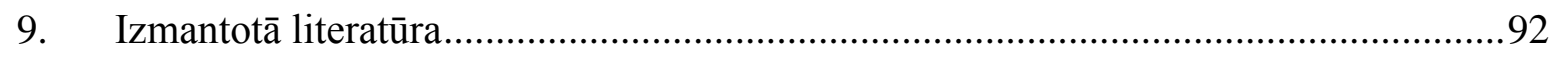

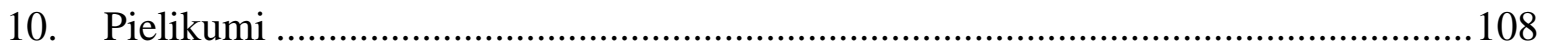




\title{
DARBĀ LIETOTIE SAIISINĀJUMI
}

\author{
Apzīmējums Skaidrojums \\ 95\% HPD 95\% augstākās varbūtības blīvums \\ aa Aminoskābe(s) \\ BKUS Valsts sabiedrības ar ierobežotu atbildību „Bērnu klīniskā universitātes \\ slimnīca" Torņakalna novietne \\ bp Bāžu pāri \\ BSP Baijesa apvāršņa grafiks \\ cDNS Komplementārā DNS \\ $d N \quad$ Ne-sinonīma mutācija - kodējošās sekvences nukleotīda nomaiņa, kuras \\ rezultātā aminoskābju sekvence mainās \\ $d N / d S \quad$ Ne-sinonīmo/sinonīmo mutāciju attiecība \\ DNS Dezoksiribonukleīnskābe \\ $d S \quad$ Sinonīma mutācija - kodējošās sekvences nukleotīda nomaiṇa, kuras \\ rezultātā nemainās aminoskābju sekvence \\ dsDNS Dubultpavediena DNS \\ FEL Nemainīgas ietekmes paticamības metode selekcijas spiediena noteikšanai \\ Fr Francijas kateteru skalas mērvienība (1 Fr katetram ir 1/3 mm diametrs) \\ HRSV Cilvēka respiratorais sincitiālais vīruss \\ HRSV-A A grupas cilvēka respiratorais sincitiālais vīruss, viena no divām \\ galvenajām antigēnajām grupām \\ HRSV-B B grupas cilvēka respiratorais sincitiālais vīruss, viena no divām \\ galvenajām antigēnajām grupām \\ HVR Hipervariablais reǵions \\ IFA Imūnfluorescences tests \\ IFEL Iekšējās nemain̄̄gās ietekmes paticamības metode selekcijas spiediena \\ noteikšanai \\ IV Intravenozs(i) \\ kB Kilobāze(s); 1000 bāžu pāri \\ KSS Klīniskā smaguma skala
}


LIC SIA „Rīgas Austrumu klīniskā universitātes slimnīca” stacionārs „Latvijas Infektologijas centrs"

MCC Maksimālās radniecības ticamības filoğenētiskais koks

MCMC Markova ķēdes Montekarlo algoritms

MEME Dažādu ietekmju molekulārās evolūcijas metode selekcijas spiediena noteikšanai

MIP $1 \alpha \quad$ Makrofāgu iekaisīgais proteīns $1 \alpha$

ML Maksimālās paticamības metode

$\mathrm{Ne} \quad$ Efektīvās populācijas izmērs

NFA Nazofaringeālais aspirāts

NJ Neighbor-joining ātrās klasterizācijas algoritms

nt Nukleotīds(i)

PCR Polimerāzes ķēeses reakcija

pmol Pikomols

PVO Pasaules Veselības organizācija

RDNI Respiratorā distresa novērtēšanas instruments

REL Nejaušas ietekmes paticamības metode selekcijas spiediena noteikšanai

RNP Ribonukleoproteīns

RNS Ribonukleīnskābe

RT-PCR Apgrieztās (reversās) transkripcijas PCR

SD Standartnovirze

SIRS Sistēmiska iekaisuma atbildes sindroms

SLAC Vienas paticamības ciltstēvu skaitī̌sanas metode selekcijas spiediena

noteikšanai

SPKC Slimību profilakses un kontroles centrs

ssDNS Vienpavediena DNS

ssRNS Vienpavediena RNS

tMRCA Kopīgā ciltstēva laiks

$\pi$

Nukleotīdu polimorfisms (vidējais nukleotīdu nomaiņu skaits novietojumā)

$\tau$

Paaudzes ilgumu gados 


\section{IEVADS}

Smaga respiratora infekcija zīdaiņiem, kas atbilst cilvēka respiratorajam sincitiālajam vīrusam $\left(\mathrm{HRSV}^{1}\right.$ ), tika aprakstīta jau vairāk kā pirms 150 gadiem [Black, 2003]. Retrospektīvi pētot patolog̣isko materiālu arhīvus, senākā patoloǵiskās anatomijas liecība ir atrasta 1931. gadā pagatavotā priekšmetstikliṇā [Johnson et al., 2007]. Adams aprakstīja akūtas dzilāko elpceļu infekciju uzliesmojumu zīdaiņu aprūpes iestādē 1937. gadā, viņš arī izteica hipotēzi par tās virālo etioloǵiju un sezonalitāti [Adams, 1941]. HRSV pirmo reizi tika izolēts 1956. gadā no šimpanzes ar elpceļu saslimšanu un sākotnēji tika dēvēts par „šimpanzes iesnu aǵentu”2 [Morris et al., 1956]. Jau gadu vēlāk tas tika izdalīts arī no bērna ar respiratoru infekciju [Chanock and Finberg, 1957], bet savu pašreizējo nosaukumu tas ieguva pēc patologisko izmainu apraksta elpcę̧u šūnās. Turpmākajos gados tika atklāts, ka HRSV ir visbiežākais virālais dziḷāko elpceļu infekciju ierosinātājs bērniem ar lielu mirstību jaunattīstības valstīs un milzīgu ekonomisko slogu veselības finansējumam visā pasaulē. Pēdējos gados ir apzināta arī liela morbiditāte un mortalitāte augsta riska pieaugušo un vecu ļaužu populācijās, kur mirstība ir pat lielāka kā bērnu populācijā [Falsey et al., 2005].

Mitrināta skābekḷa terapija cianotiskiem pacientiem un hidratācija tiek rekomendēta HRSV dziļāko elpceļu infekcijas ārstěšanā kopš 60. gadiem [Reynolds and Cook, 1963] un mūsdienās terapija, būtībā, nav daudz mainījusies [American Academy of Pediatrics, Subcommittee on Diagnosis and Management of Bronchiolitis, 2006; Scottish Intercollegiate Guidelines Network, 2006]. Bērnu mirstības samazināšanās no HRSV infekcijas attīstîtajās valstīs ir galvenokārt saistîta ar vispārīgu medicīnas attīstību. Pasaulē kopš 1998. gada augsta riska zīdaiņiem ir pieejama imūnprofilakse ar monoklonālo antivielu palivizumabu, kas Latvijā tiek lietots kopš 2009. gada [Perevoščikovs un Lucenko, 2010]. Tomēr šī preparāta dārdzība (viena flakona cena ir LVL 955, t.i. gandrīz 5000 LVL sezonā vienam pacientam; http://www.zva.gov.lv) ierobežo pielietošanu plašākai populācijai [American Academy of Pediatrics Committee on Infectious Diseases,

\footnotetext{
${ }^{1}$ Human respiratory syncytial virus.

${ }^{2}$ Chimpanzee coryza agent.
} 
2009]. Lai arī vakcīna ir medicīniska nepieciešamība un būtu ekonomiski izdevīga [Meijboom et al., 2012], gandrīz 50 gadu laikā tā arī nav izdevies radīt licencētu produktu [Anderson et al., 2013]. Patiesībā, HRSV pētniecības vēsture ir saistîta ar vienu no neveiksmīgākajiem vakcinācijas mēǵinājumiem pediatrijā [Black, 2003]. 1966. gadā ASV tika veikta bērnu imunizācija ar polivalentu vakcīnu, kas saturēja formalīnā inaktivētu HRSV. Šī vakcīna ne tikai nepasargāja no infekcijas, bet $80 \%$ ar HRSV inficēto bērnu tika stacionēti un divi no viniiem nomira, kamēr placebo grupā stacionēti tika tikai $5 \%$ un netika konstatēti nāves gadījumi.

Drošas vakcīnas izstrādāšana un ieviešana ir viena no globālajām prioritātēm. Šo uzdevumu būtiski apgrūtina HRSV lielā genētiskā mainība. Vienlaicīgi cirkulē vairāki HRSV genotipi, kurus periodiski nomaina jauni. Genotipu izplatība ir sarežğìta, jo vīrusa celmi īsā laika periodā spēj šşērsot plašas ǵeogrāfiskās robežas. Reǵionālai HRSV molekulārajai uzraudzībai ir būtiska nozīme HRSV virusoloǵisko īpašìbu izpētē, jaunu virulences faktoru prognozēšanā, diagnostisko testu izstrādē un populācijai piemērotu vakcīnu celmu selekcijā. Apkopojot vietējos un globālos datus, ir iespējams rekonstruēt vīrusa populācijas izmēra pārmainas un geogrāfisko izplatīibu, kas ļauj identificēet epidēmijas izplatî̌šanās cel̦us un veicināt sabiedrības veselības stratẹgiju izstrādāšanu. Latvijā HRSV epidemiologija ir vāji apzināta - tā incidence un slimības slogs nav zināmi, pieejamie dati rada tikai aptuvenu priekšstatu. Latvijā cirkulējošo HRSV celmu molekulārā struktūra iepriekš nav pētīta.

\section{Darba mērķis}

Raksturot HRSV izraisīto dziḷāko elpcelı infekciju klīniskās īpatnības un terciārā līmeņa bērnu slimnīcā cirkulējošo celmu molekulāro epidemioloğiju trīs secīgu respiratoro vīrusu sezonu laikā Latvijā. 


\section{Darba uzdevumi}

1. Izstrādāt polimerāzes ķēdes reakcijas (PCR) testu HRSV diagnostikai un ǵenētisko grupu diferencēšanai;

2. noteikt HRSV izplatību stacionētiem agrīna vecuma bērniem ar dziḷāko elpcel̦u infekciju;

3. izpētīt HRSV sezonalitāti trīs gadu laikā;

4. noteikt HRSV grupu un genotipu iespējamo saistību ar to izraisītās infekcijas smagumu;

5. analizēt HRSV celmu filoǵenēzi un mainību;

6. izmantojot $\mathrm{G}$ gēna ǵenealoǵiju, rekonstruēt HRSV demogrāfiskās un ǵeogrāfiskās izkliedes parametrus.

\section{Darba hipotēzes}

1. HRSV molekulārā epidemioloǵija Latvijā būtiski neatšķiras no citām valstīm, tomēr pastāv lokālo celmu iespējamība;

2. pastāv korelācija starp HRSV molekulāro raksturojumu un slimības norises smagumu;

3. pielietojot molekulārā pulksteņa principu ar izolēšanas laiku un vietu iezīmētām HRSV genoma sekvencēm, iespējams rekonstruēt tā globālo izplatību. 


\section{LITERATŪRAS APSKATS}

\subsection{Virālo dziḷāko elpceḷu infekciju slogs bērniem}

Akūtas dziḷāko elpceļu infekcijas ir galvenais nāves cēlonis agrīna vecuma bērniem pasaulē. Pasaules Veselības organizācijas (PVO) cēloņspecifiskās mirstības sadalījumā bērniem vecumā līdz pieciem gadiem 2010. gadā pneimonija bija vadošais nāves cēlonis; tā bija izraisīja 19\% jeb 1,4 miljonus nāves gadījumu šajā vecuma grupā [World Health Organization, 2012]. Lai arī kopš 1990. gada mirstību no šīm infekcijām ir izdevies ievērojami samazināt, tā joprojām ir galvenais šķērslis, lai sasniegtu Apvienoto Nāciju Organizācijas Tūkstošgades attīstības 4. mērksi - samazināt bērnu mirstību par divām trešdaļām līdz 2015. gadam [Lozano et al., 2012; United Nations, 2012; http://www.who.int/topics/millennium_development_goals/en/]. Dziḷāko elpcel̦u infekcijas mirstības etiologijāā pasaulē vadošā loma ir diviem bakteriāliem patogēniem Streptococcus pneumoniae un Haemophilus influenzae, kam seko HRSV un vairāki citi virāli aǵenti, galvenokārt masalu vīruss un gripas vīrusi A un B [Lozano et al., 2012; Nair et al., 2010; Rudan et al., 2008]. 70\% no dziļāko elpceḷu infekcijas nāves gadījumiem ir lokalizēti Subsahāras Āfrikā un Dienvidaustrumāzijā, kur šo mirstību būtiski ietekmē tādi blakus faktori kā mulnutrīcija un imunizācijas trūkums [Roth et al., 2008; Rudan et al., 2008].

Pielietojot molekulārās tehnoloğijas, mūsdienās viens vai vairāki virālie aǵenti tiek detektēti līdz pat 95\% bērnu ar bronhiolītu un līdz pat $72 \%$ bērnu ar pneimoniju [Jartti et al., 2013]. Attīstītajās valstīs bērnu mirstība no vīrusu izraisītas dziḷāko elpceḷu infekcijas ir zema. Tomēr kā visbiežākais agrīna vecuma bērnu hospitalizācijas iemesls [Shay et al., 1999], tās rada būtisku sociālo un ekonomisko slogu. Katru gadu 3-10\% no visiem bērniem jaunākiem par vienu gadu tiek stacionēti ar vidēji smagu vai smagu dziḷāko elpcel̦u infekciju [Henrickson et al., 2004; Shay et al., 1999]. Aptuveni vienai trešdaḷai stacionēto bērnu ir hroniskas medicīniskas problēmas, visbiežāk, neiznestība, imūnsupresija vai kardiopulmonāla slimība [Henrickson et al., 2004]. ASV ar bronhiolītu stacionēto bērnu vecumā līdz diviem gadiem tiešās medicīniskās izmaksas ik gadu pārsniedz 500 miljonu dolāru, turklāt pacienta individuālās izmaksas ir divkārt lielākas, ja tiek diagnosticēta

pneimonija [Pelletier et al., 2006]. Kopējais ekonomiskais slogs, ierēķinot ambulatorās un 
uzṇemšanas nodaļu izmaksas, kā arī vecāku kavētās darbadienas, ir aptuveni piecas reizes lielāks [Leader and Kohlhase, 2003].

Neskatoties uz kopīgajām slimības izpausmēm, cilvēkam patogēni ir vismaz 26 respiratorie vīrusi [Ruuskanen et al., 2011], kas pieder dažāāām vīrusu kārtām un ir genētiski un imunolog̣iski atšķirīgi. 1.1. tabulā uzskaitīiti galvenie respiratorie vīrusi, kas ir asociēti ar dziḷāko elpceļu infekciju, kā arī noradīta to klasifikācija. Pēdējo gadu laikā, attīstoties molekulārajām tehnoloǵijām, ir radīti vairāki multiplex diagnostiskie paneḷi, kas ļauj noteikt pat 15 un vairāk ierosinātājus vienlaicīgi. Šādi diagnostiskie instrumenti ar augstu jutību laaj noteikt kultūrās grūti izolējamu vīrusu (piem., cilvēka rinovīrusa) genoma klātbūtni un samazināt nediferencētu dziļāko elpceļu infekciju skaitu līdz dažiem procentiem [Jartti et al., 2013]. Tādējādi iespējams samazināt antibakteriālo līdzekḷu patēriņu un panākt labāku pacientu kohortēšanu slimnīcā, mazinot intrahospitālās pārneses risku. Tomēr šādam plašam skrīningam ir arī vairāki trūkumi: nereti vīrusu (īpaši cilvēka rinovīrusa un bokavīrusa) klātbūtne tiek noteikta asimptomātiskiem bērniem (līdz pat 68\% gadījumu), un ne visu jaunatklāto vīrusu (cilvēka koronavīrusi un bokavīruss) kauzalitāte ir labi pierādīta [Jartti et al., 2013; Pavia, 2011]. 


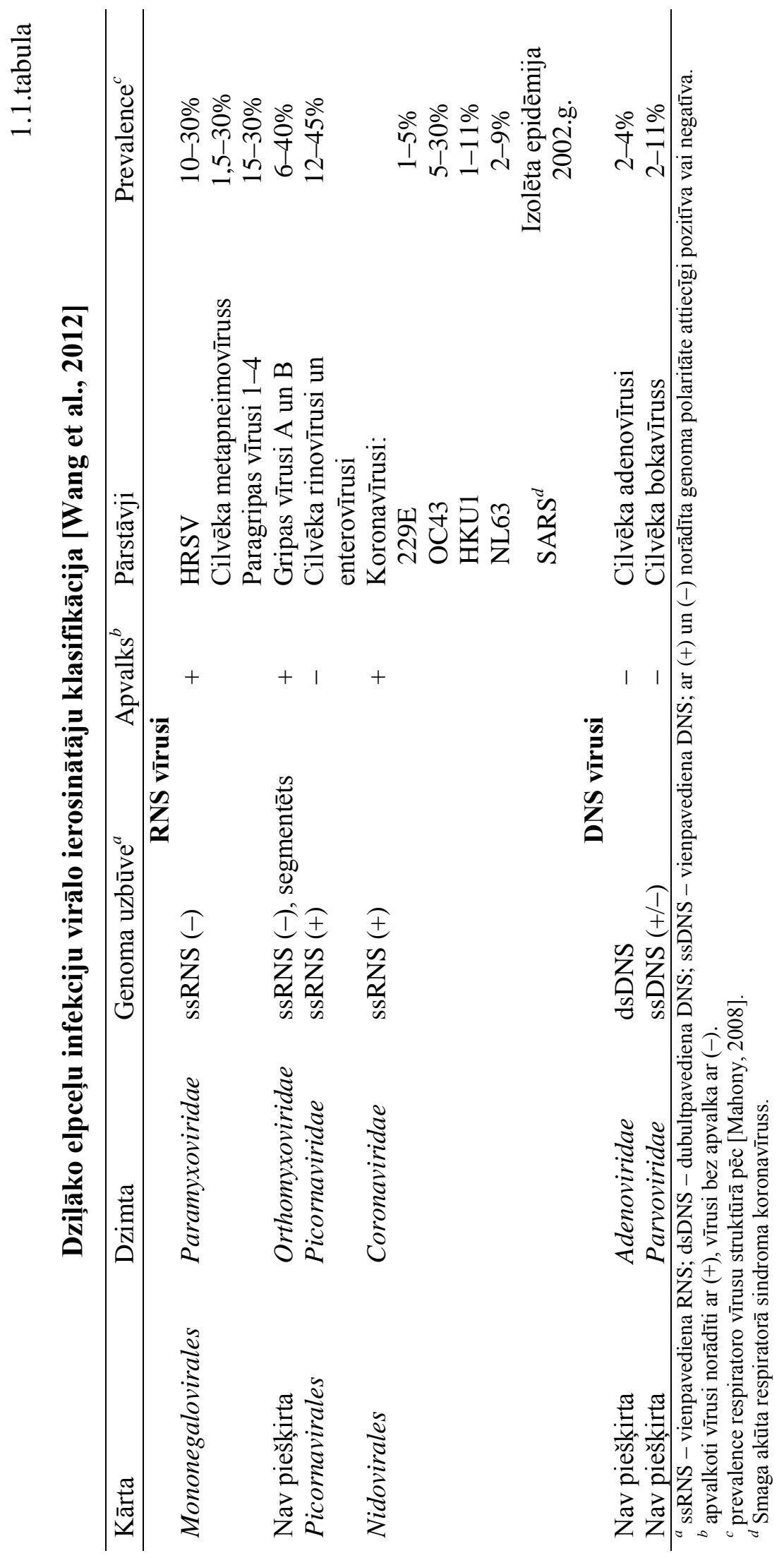




\subsection{HRSV raksturojums}

\subsubsection{Epidemioloğija}

Pēc epidemioloǵiskiem aprēķiniem HRSV katru gadu pasaulē izraisa aptuveni 33,8 miljonus jaunas infekcijas bērniem vecumā līdz pieciem gadiem [Nair et al., 2010]. Apmēram 10\% inficēto bērnu attīstās smaga dziḷāko elpceḷu infekcija, kuriem nepieciešama hospitalizācija, un kopējā ikgadējā mirstība šajā vecumā tiek lēsta ap 234000 [Lozano et al., 2012], t.i. HRSV ir ierosinātājs vairāk nekā 15\% gadījumos, kad bērna nāves iemesls ir dziḷāko elpceļu infekcija. Kopējā gadījuma mirstība no HRSV izraisītās dziḷāko elpceļu infekcijas jaunattīstība valstīs ir 2,1\% [Nair et al., 2013]. Lielāku mirstību šajā vecuma un diagnozes grupā izraisa tikai Streptococcus pneumoniae un Haemophilus influenzae b tips. 99\% no šiem nāves gadījumiem ir reǵistrēti jaunattīstības valstīs [Nair et al., 2010]. Industrializētajās valstīs gadījuma mirstība no HRSV dziḷāko elpceḷu infekcijas ir aptuveni septiņas reizes mazāka - 0,3\% [Nair et al., 2010], bet populācijas mērogā bērniem zem viena un piecu gadu vecuma tā ir attiecīgi 3,1 un 0,1 uz 100000 persongadiem, hospitalizētiem pacientiem tā ir <1\% [Leader and Kohlhase, 2003; Thompson et al., 2003]. Mirstība ir vairāk nekā trīs reizes augstāka pacientiem ar pavadošām slimībām, galvenokārt neiznestību, hemodinamiski nozīmīgu iedzimtu sirdskaiti (īpaši gadījumos, kad tā saistīta ar plaušu hipertensiju) un hronisku plaušu slimību (saistībā ar neiznestību, cistiskā fibroze u.c.) [Shay et al., 2001].

Ikgadējie uzliesmojumi ir saistīti ar milzīgu slogu veselības budžetam. Līdz gada vecumam ar HRSV inficējas aptuveni 70\% bērnu, bet līdz divu gadu vecumam - vairāk kā 90\% [Glezen et al., 1986; Simões and Carbonell-Estrany, 2003]. HRSV konstatē aptuveni 45\% no hospitalizētiem bērniem ar dziļāko elpcȩ̣u infekciju, kas jaunāki par diviem gadiem [Simões and Carbonell-Estrany, 2003]. Neiznestība un jaunāks vecums (zem sešiem mēnešiem) ir neatkarīgi riska faktori hospitalizācijai [Hall et al., 2009]. Citi aprakstītie riska faktori, kas saistīti ar hospitalizāciju, ir vīriešu dzimums, hroniskas blakus slimības, zems sociāli ekonomiskais stāvoklis, pasīvā smēķēšana, īsāks krūts ēdināšanas periods un kontakts ar citiem bērniem ǵimenē [Holberg et al., 1991; Nielsen et al., 2003]. Tomēr absolūti lielākā daļa hospitalizēto bērnu ir bijuši iepriekš veseli [Hall et al., 2009]. 
Pēdējos gados hospitalizācijas biežums sakarā ar HRSV izraisītu bronhiolītu pieaug, ko visticamāk veicinājusi plaša pulsoksimetrijas pielietošana, lai identificētu hipoksēmiskus pacientus [García et al., 2010].

Vecāki l̦audis un pieaugušie ar hroniskām kardiopulmonālām slimībām un imūnsupresēti indivīdi arī ietilpst smagas HRSV infekcijas riska grupā [Falsey et al., 2005]. Patiesībā, 88\% ar HRSV asociēto nāves gadījumu ir vecuma grupā virs 65 gadiem [Thompson et al., 2003]. ASV ar HRSV ik gadu inficējas 5-10\% pansionātu iemītnieki un gadījuma mirstība sasniedz 2-8\% [Falsey et al., 2000].

Lai arī HRSV ir tikai viens serotips, pēc infekcijas neizveidojas pasargājoša imunitāte, tāpēc dz̄̄ves un pat vienas sezonas laikā ir iespējams inficēties atkārtoti [Henderson et al., 1979; Simões, 1999; Simões and Carbonell-Estrany, 2003].

Vēl viens būtisks HRSV epidemiologiskais aspekts ir nozokomiālā pārnese, kuras pamatā ir tā augstā kontagiozitāte; tas ir viens no biežākajiem nozokomiālo infekciju aǵentiem pediatriskajās nodaḷās. Intrahospitālā HRSV infekcija ir saistīta ar ievērojami ilgāku uzturēšanos slimnīcā un lielāku mirstību, salīdzinot ar sadzīvē iegūtu infekciju [Langley et al., 1997]. Slimnīcas personāls ir galvenais infekcijas avots. Lai arī lielākajai daļai medicīniskā personāla ir saaukstēšanās simptomi, 15-20\% inficēto darbinieku var būt asimptomātiski [Hall, 2000]. Vīrusa nukleīnskābi var atrast arī uz priekšmetiem inficēto pacientu palātās [Geis et al., 2013].

Latvijā HRSV epidemioloǵiskās uzraudzības dati ir skopi - Slimību profilakses un kontroles centra Epidemiologijas Biḷetens ziṇo tikai kopējo HRSV pozitīivi testēto paraugu skaitu pa epidemiologiskajām nedēḷām, neizdalot tos pa vecuma un diagnožu grupām un bez populācijas saucēja [N̦ikiforova un Pumane, 2013]. Ir zināms, ka HRSV īpatsvars starp pārbaudītajiem respiratorajiem vīrusiem Latvijā pēdējos gados ir bijis no 15-47\% [Nikiforova et al., 2011]. Incidences, mirstības un sezonalitātes dati nav zināmi.

\subsubsection{Virusoloğiskais raksturojums}

HRSV ir klasificēts Pneumovirus ǵintī, Pneumovirinae apakšdzimtā, Paramyxoviridae dzimtā. Atbilstoši tas ir citoplazmatisks apvalkots vīruss ar vienas 
molekulas, lineāru, negatīvas ssRNS genomu, kas neveido rekombinācijas [Wang et al., 2012]. HRSV virioni ir pleomorfi ar sfērisku (lielākā daļa) vai filamentozu (aptuveni 5\%) formu, vai abu kombināciju, izmērā no 100 līdz 1000 nm [Liljeroos et al., 2013]. HRSV virālā RNS ir aptuveni 15,2 kB gara un tās 10 gēni kodē 11 proteīnus [Collins and Crowe, 2007]: 9 no tiem ir strukturālie un virsmas glikoproteīni, atlikušie 2 ir iesaistīti replikācijas regulēšanā (1.1. attēls).
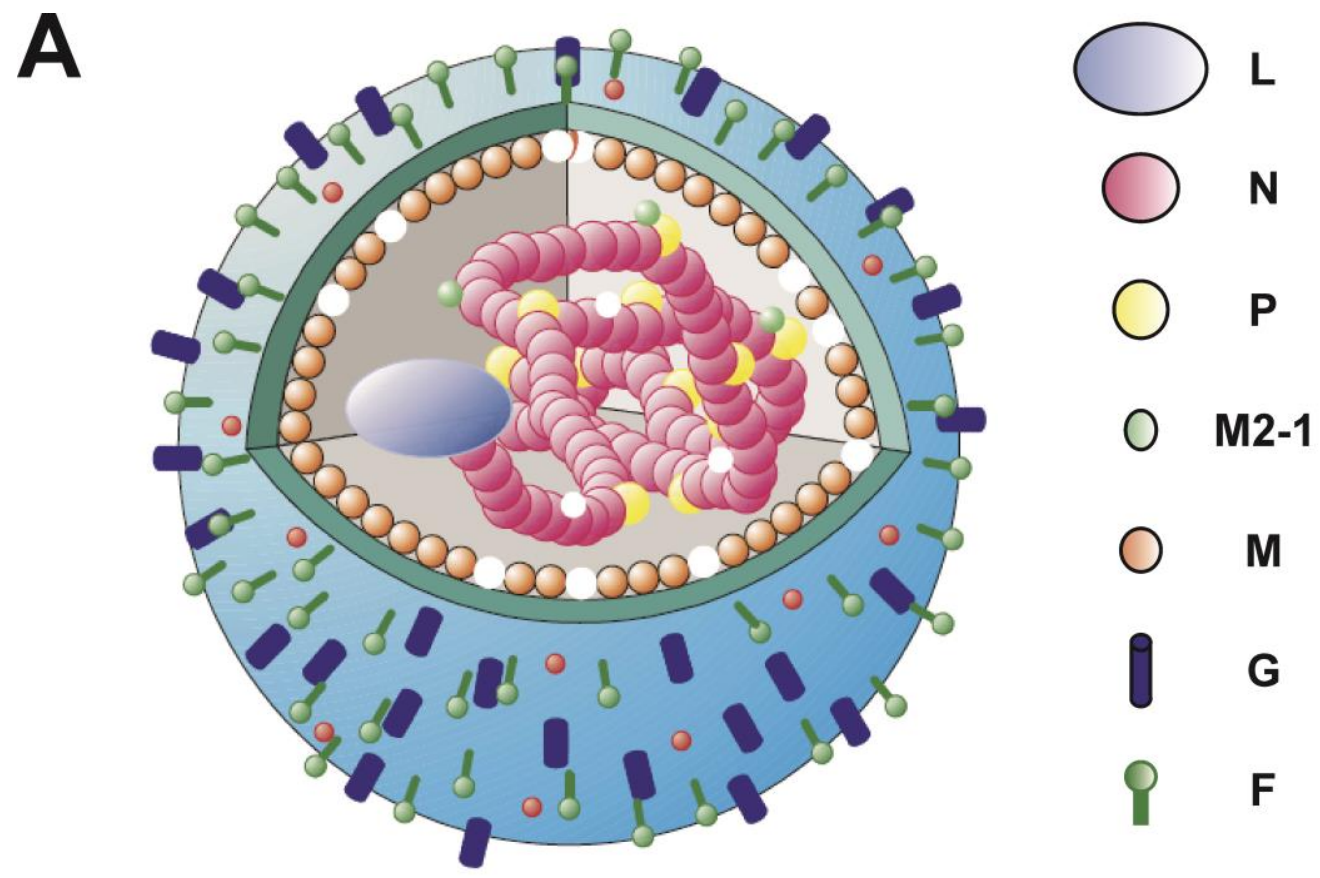

P $\mathbf{F}$

O SH

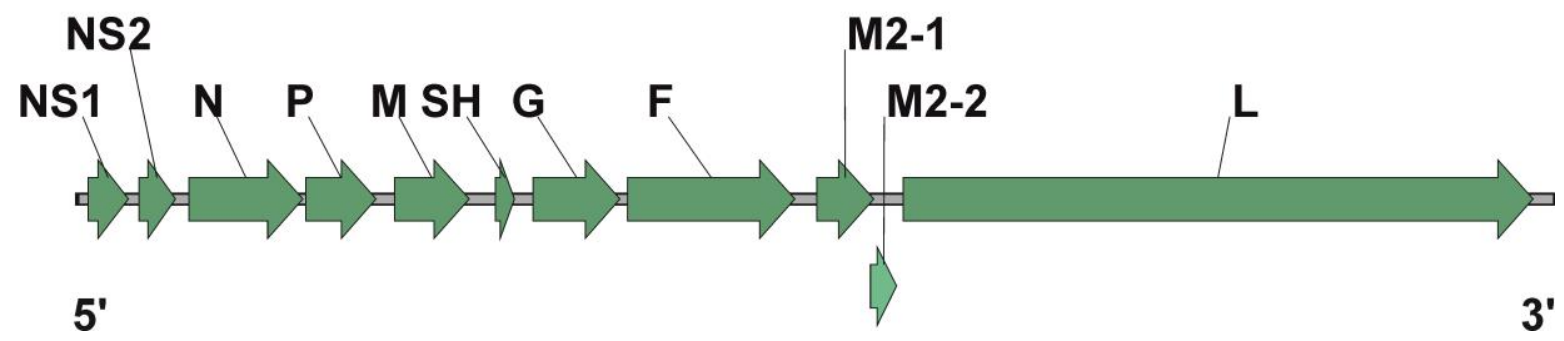

\section{1. att. HRSV genoma uzbūve}

A, viriona shēma [Melero, 2007]; B, genoma shēma. Nukleoproteīns N ir cieši saistìts ar genoma RNS; L proteīns ir galvenā polimerāzes subvienība; fosfoproteīns P ir nozīmīgs kofaktors RNS sintēzē; M2-1 un M22 proteīni regulē RNS transkripciju; matricas M proteīns veido vīrusa iekšējo apvalku; glikozilētais G, fūzijas F un mazais hidrofobais SH ir virsmas glikoproteīni; NS1 un NS2 ir nestrukturālie proteīni, un tiem ir loma imūnās atbildes nomākšanā [Collins and Graham, 2008]. 
Lai inficētu šūnas, vīruss izmanto virsmas glikoproteīnus G un F, kuriem nepiemīt neiraminidāzes un hemaglutinīna aktivitātes. Šie proteīni ir arī primārie neitralizējošo antivielu mērksi un lielā mērā nosaka vīrusa infekciozitāti un patoǵenēzi [Connors et al., 1991]. G proteīns nodrošina vīrusa pieķeršanos mērķa šūnai, un tas ir antigēni un genētiski vismainīgākais HRSV proteīns [Sullender, 2000]. F proteīns nodrošina vīrusa un mērķa šūnas plazmatiskās membrānas saplūšanu, vīrusam nokḷūstot šūnas citoplazmā. F proteīns spēlē lomu raksturīgo sincītiju (daudzkodolainu agregātu, ko veido šūnas ar saplūdušām plazmatiskajām membrānām) formēšanā šūnu kultūrās [Peters and Crowe, 2008]. HRSV membrānā ir inkorporēti arī mazais hidrofobais glikoproteīns SH, kura funkcija nav zināma, un celulārie proteīni tādi kā aktīns un šaperoni [Liljeroosa et al., 2013]. Virālā RNS nonāk šūnas citoplazmā kā spirālveida ribonukleoproteīnu (RNP) komplekss, to veido viena molekula RNS, kuru ieskauj nukleoproteīni N un RNS atkarīgā RNS polimerāze [Tawar et al., 2009]. Šāds komplekss, iespējams, samazina toll-like receptoru (TLR) virālās RNS atpazīšanu. Vēl virionā atrodas matricas proteīns $M$ un transkripcijas antiterminators M2-1, ar apvalku saistīts proteīns, kas mediē RNP saistību ar M proteīnu [Liljeroosa et al., 2013]. Virālo gēnu ekspresija norit šūnas citoplazmā, bet lipīdu apvalku virioni iegūst, pumpurojoties no citoplazmatiskās membrānas [Collins and Graham, 2008].

\subsubsection{Klīniskās izpausmes}

HRSV izraisa stabilus, prognozējamus ikgadējus uzliesmojumus, kas mērenajā klimata joslā sakrīt ar ziemas un pavasara (novembris - aprīlis), bet tropiskajā klimata joslā ar lietus sezonas mēnešiem (maijs - decembris) [Bloom-Feshbach et al., 2013; Langley et al., 2013]. Lai arī atšķirīgu iemeslu dēḷ, šie ir periodi, kad bērni pārsvarā pulcējās iekštelpās. Infekcijas tropisms parasti ir ierobežots ar virsmas epitēlija šūnām. HRSV RNS ir izdalīta arī no asinīm [O’Donnell et al., 1998], miokarda [Bowles et al., 2003], aknām [Nadal et al., 1990] un cerebrospinālā šķidruma [Zlateva and van Ranst, 2004], tomēr tiešs vīrusa izraisīts iekaisums šajos orgānos nav pierādīts. Vīrusa inokulācija degunā vai acīs notiek gaisa-pilienu vai tieša kontakta cel̦ā, pēc kā norit vīrusa replikācija aizdegunē ar inkubācijas periodu no 3 līdz 5 dienām [Collins and Crowe, 2007]. Biežākās slimības 
sākuma izpausmes ir rinīts, klepus un subfebrila temperatūra. Bieža infekcijas komplikācija ir vidusauss iekaisums - līdz pat $70 \%$ inficēto pacientu vīruss izolējams arī no vidusauss šķidruma ar vai bez bakteriālas ko-infekcijas [Andrade et al., 1998; Fleming et al., 2005; Heikkinen and Ruuskanen, 1995; Heikkinen et al., 1999]. Gandrīz pusei pirmreizēji inficēto zīdaiņu vīruss nākamajās dienās izplatās tālāk uz dzị̄ākajiem elpceḷiem. Bronhiolu skropstiņepitēlijs un 1. tipa alveolocīti ir primārais mērķis dzilāaajos elpceļos [Johnson et al., 2007]. Šeit epitelija šūnu nekroze, intralumināls nosprostojums ar atmirušajiem audiem, gḷotām un eksudātu, bronhiolu sieniņas tūska un bronhospazma rada ventiļa efektu ar perifêro plaušu daļu hiperventilāciju un atelektāzēm [American Academy of Pediatrics Subcommittee on Diagnosis and Management of Bronchiolitis, 2006; Pipavath et al., 2005]. Dziḷāko elpceḷu infekciju klīniski raksturo atteikšanās no ēdiena un palielināts elpošanas darbs, ko raksturo ātra elpošana, elpošanas palīgmuskulatūras iesaiste, stenēšana un deguna spārnu cilāšanās [American Academy of Pediatrics Subcommittee on Diagnosis and Management of Bronchiolitis, 2006; Hall et al., 2009; Wennergren and Kristjánsson, 2001]. Pacientiem ar bronhiolītu ir raksturīga palielināta elpceļu pretestība ar "gāzes lamatām", kas klīniski izpaužas kā sēkšana (gan auskultējama, gan per distance) ar pagarinātu izelpu, virs plaušu laukiem auskultējami arī mitri trokšnini. Lai arī diagnozes noteikšanai pietiek ar anamnēzi un klīniskajām izpausmēm [American Academy of Pediatrics Subcommittee on Diagnosis and Management of Bronchiolitis, 2006], ja tiek veikta krūškurvja rentgenogramma, tajā ir redzama plaušu hiperinflācija, peribronhiāli sabiezējumi un segmentāras atelektāzes [Peters and Crowe, 2008]. Pacientiem ar pneimoniju auskultējamas krepitācijas un radioloǵiski atrodama alveolāra, segmentāra vai lobāra konsolidācija. Gan bronhiolīts, gan pneimonija var izraisīt hipoksēmiju, kas bieži atrodama HRSV inficētiem pacientiem, veicot pulsoksimetriju [Collins and Graham, 2008; Simões, 1999]. Hipoksēmija stacionēšanas brīd̄ī, kuru izraisa plaušu ventilācijas-perfūzijas neatbilstība bronhiolīta gadījumā vai intrapulmonālais šunts pneimonijas gadījumā, ir visbūtiskākais prognostiskais faktors komplicētai slimības gaitai - ilgākai hospitalizācijai, uzņemšanai intensīvās terapijas nodạ̦ā un mākslīgajai plaušu ventilācijai [Shaw et al., 1991; Wang et al., 1995]. Bakteriāla superinfekcija attīstītajās valstīs ir reta, tā biežāk sastopama mazattīstìtajās valstīs, kas ir viens no izskaidrojumiem palielinātai mirstībai [Nair et al., 2010; Simões, 1999]. Salīdzinoši retāka (1\% no hospitalizētajiem bērniem), bet potenciāli 
dz̄ivībai bīstama izpausme, apnoja, ir sastopama par diviem mēnešiem jaunākiem zīdaiņiem [Hall et al., 2009]. Šiem bērniem arī biežāk vērojamas atelektāzes krūškurvja rentgenogrammā. Biežu apnoju gadījumā var būt nepieciešama mākslīgā plaušu ventilācija arī bez citām elpošanas mazspējas izpausmēm. Nekomplicēta HRSV izraisīta slimība ir pašlimitējoša un parasti tā ilgst 1-4 nedēḷas [Hall et al., 2009]. Imūnkompetentu pieaugušo elpošanas trakts pēc infekcijas no HRSV atbrīvojas jau 3-6 dienu laikā [Falsey and Walsh, 2000]. Inficēti bērni turpina izdalīt vīrusu vidēji 11 dienas [von Linstow et al., 2006]. Vīrusa izdalīšanas laiku bez vecuma nosaka arī personas imūnais stāvoklis, respektīvi, imūnsupresētas personas vīrusu izdala ilgāk, vairākus mēnešus līdz pat pusgadam [Black, 2003; Geis et al., 2013; Houspie et al., 2013]. HRSV infekcijas izraisīta sēkšana daļai pacientu ir pārejoša, savukārt citiem sēkšanas epizodes atkārtojas vai sakrīt ar astmas simptomu sākumu. HRSV loma astmas patoǵenēzē ir daudz diskutēta, un šobrīd pastāv uzskats, ka smaga HRSV infekcija predisponē tās attīstību [Wennergren and Kristjánsson, 2001].

HRSV infekcijas patoǵenēzē būtisks ir gan tiešs vīrusa radīts bojājums, gan organisma imūnas atbildes reakcijas. Par to liecina klīniskie pētījumi, kuros, atsevišksi lietojot antivirālus [Lagos et al., 2009; Malley et al., 1998] un pretiekaisuma [Krilov, 2011; Ferenandes et al., 2010] preparātus, tika iegūts minimāls klīniskais efekts.

\subsection{4. Ārstēšana}

Neskatoties uz to, ka ir veikti aptuveni 100 randomizēti kontrolēti pētījumi, akūtas virālas dziļāko elpceḷu infekcijas un specifiskas HRSV infekcijas ārstēšana joprojām balstās uz vispārīgiem, atbalstošiem principiem, kur skābekḷa terapija hipoksēmiskiem pacientiem, elpcel̦u sekrētu atsūkšana un hidratācija caur nazogastrālo zondi vai intravenozi ir terapijas stūrakmeņi. Lai arī plaši lietotas pēc ,,veselā saprāta” principa, skābekḷa inhalāciju drošības profils un efektivitāte bērniem ar dziḷāko elpcel̦u infekciju nekad nav izpētīti randomizētos kontrolētos pētījumos [Rojas et al., 2009]. Pašreizējās skābekḷa

terapijas vadlīnijas balstās uz oksihemoglobīna disociācijas līknes patofiziologisisku izpratni un tiek rekomendēta, kad arteriālo asiṇu skābekḷa saturācija samazinās zem 90\% [American 
Academy of Pediatrics Subcommittee on Diagnosis and Management of Bronchiolitis, 2006].

Bronhodilatatori bronhiolīta ārstēšanā ir salīdzinoši bieži lietoti preparāti klīniskajā praksē. Bronhodilatējošs efekts ir inhalējamiem $\beta_{2}$-adrenerǵiskajiem līdzekḷiem, no kuriem visbiežāk tiek lietoti salbutamols un adrenalīns. Sašaurinot asinsvadus, adrenalīns var papildus samazināt arī gḷotādas tūsku [Skjerven et al., 2013]. Tomēr nevienam no šiem preparātiem nav pārliecinoša efekta randomizētos kontrolētos pētījumos [Langley et al., 2005; Patel et al., 2002; Skjerven et al., 2013] un meta-analīzē [Gadomski and Brower, 2010; Hartling et al., 2011] gan ambulatoriem, gan hospitalizētiem pacientiem. Kopumā aptuveni vienam no četriem bronhiolīta pacientiem būs īslaicīgs uzlabojums no bronhodilatatoru lietošanas, bet tā klīniskā nozīmība ir neskaidra [American Academy of Pediatrics Subcommittee on Diagnosis and Management of Bronchiolitis, 2006]. Nesen Skjervens ar kolēgiem veica multicentru dubultaklu randomizētu kontrolētu pētījumu, kur tika salīizinātas racēmiskā adrenalīna inhalācijas ar placebo $(0,9 \% \mathrm{NaCl})$ inhalācijām divos dažādos režīmos - pēc pieprasījuma un pēc stingra grafika [Skjerven et al., 2013]. Adrenalīna inhalācijas nebija pārākas par placebo, savukārt inhalāciju režīmam bija būtiska nozīme. Pacienti, kas saṇēma inhalācijas „,pēc pieprasījuma”, tās saṇēma ievērojami retāk un hospitalizācijas ilgums, kā arī nepieciešamība pēc skābekḷa un mākslīgās plaušu ventilācijas, bija mazāks. Šis pētījums apliecina, ka bronhodilatatoru inhalācijas lielākajai daļai pediatrisko pacientu ir ne tikai neefektīvas, bet, nepareizi pielietotas, var radīt negatīvus efektus.

Klīniski bronhiolītam raksturīga astmai līdzīga sēkšana un tas ir saistīts ar astmas risku, turklāt imunologiskajiem mehānismiem ir liela nozīme tā patoǵenēzē. Šie apsvērumi liek domāt, ka glikokortikoīdu terapijai varētu būt efekts simptomu mazināšanā. Tomēr 17 randomizētu kontrolētu pētījumu meta-analīze liecina, ka ne inhalējamo, ne sistēmisko glikokortikoīdu lietošanai nav ievērojama klīniskā efekta [Fernandes et al., 2010].

Sintētiskajam nukleozīdam, guanozīna analogam (1- $\beta$-D-ribofuranozil-1,2,4-triazol3-karboksamīds) ribavirīnam piemīt inhibējoša aktivitāte pret vairākiem vīrusiem, t.sk. tas ievērojami samazina HRSV replikāciju in vitro [Black, 2003]. Mazos randomizētos pētījumos iegūtie klīniskie rezultāti ir pretrunīgi [Guerguerian et al., 1999; Smith et al., 1991] un datu meta-analīze liecina, ka, lai arī ribavirīnam ir potenciāls samazināt mākslīgās 
plaušu ventilācijas un hospitalizācijas ilgumu pacientiem ar HRSV pneimoniju, pašreizējo pierādījumu līmenis nȩ̣auj dot drošas rekomendācijas [Ventre and Randolph, 2007]. N̦emot vērā sarežg̀îto preparāta ievadi (tas precipitē mākslīgās plaušu ventilācijas kontūrā) un lielās izmaksas, tā lietošana ir ierobežota tikai pacientiem ar smagu imūnsupresiju, piemēram, pēc hematopoētisko cilmes šūnu vai plaušu transplantācijas [American Academy of Pediatrics Subcommittee on Diagnosis and Management of Bronchiolitis, 2006; Chemaly et al., 2012; Zamora et al., 2011].

Antibakteriālai terapijai HRSV dziḷāko elpceļu infekcijas gadījumā ir limitēta loma. Tās neuzlabo iznākumus bronhiolīta [Spurling et al., 2011] un virālas pneimonijas gadījumā [Ruuskanen et al., 2011]. Ja pacientam ir diagnosticēts akūts vidusauss iekaisums, tā ārstēšana jāveic pēc specializētajām vadlīnijām, jo klīniski nav iespējams atšķirt bakteriālu no virālas etiolog̣ijas. Citādi bakteriālas infekcijas risks ir jāvērtē tāpat kā bērniem bez HRSV [American Academy of Pediatrics Subcommittee on Diagnosis and Management of Bronchiolitis, 2006]. Azitromicīnam ir pierādīts pretiekaisuma efekts un tas uzlabo arī plaušu funkcionālos rādītājus pacientiem ar bronchiolitis obliterans [Vos et al., 2011], tomēr randomizēti klīniskie pētījumi nav uzrādījuši efektu akūta virāla bronhiolīta gadījumā [Kneyber et al., 2008; Pinto et al., 2012] .

Arī tādi līdzekḷi kā krūškurvja fizioterapija [Roqué i Figuls et al., 2012], surfaktanta instilācija [Jat and Chawla, 2012], nebulizētas rekombinantas DNāzes inhalācija [Enriquez et al., 2012], leikotriēnu antagonista montelūkasta lietošana [Amirav et al., 2008] un hēlijaskābekḷa gāzu maisījuma inhalācija [Chowdhury et al., 2013] ir neefektīivi, dod ļoti īslaicīgu efektu vai arī ietver nelabvēlīgu izmaksu-ieguvumu attiecìbu akūta bronhiolīta pacientiem.

HRSV dziḷāko elpceļu lūmenā palielina ekstracelulārās adenozina trifosfatāzes koncentrāciju, kas savukārt netieši samazina hlorīda sekrēciju un pastiprina nātrija reabsorbciju. Šīs elektrolītu izmaiņas rada elpceļu virsmas dehidratāciju un zemgḷotādas tūsku un vēl vairāk nosprosto obstruktīvo elpceḷu lūmenu, būtībā radot mukociliārā klīrensa mazspēju [Ater et al., 2012]. Pozitīvs klīniskais efekts šo teorētisko mehānismu novēršanā ir hipertoniska $\mathrm{NaCl}$ inhalācijām. Četru randomizētu kontrolētu pētījumu meta-analīze liecina, $\mathrm{ka} 3 \% \mathrm{NaCl}$ inhalācijas samazina hospitalizācijas ilgumu un atvieglo slimības 
simptomus [Zhang et al., 2008]. Šì preparāta izmaksas ir mazas, un, ņemot vērā pierādījumus, tas pagaidām ir viens no efektīvākajiem līdzekḷiem.

\subsubsection{Profilakse}

Kopš 1998. gada ir pieejama HRSV imūnprofilakse ar pasīvu antivielu ievadi. Palivizumabs ir monoklonāla antiviela pret F proteīnu, kas tiek lietots augsta riska zīdaiṇu pasīvai imūnprofilaksei. Tas ir uz peḷu monoklonālas antivielas balstīts preparāts, kas, pielietojot rekombinantās tehnologijas, ir „humanizēts” uz cilvēka imūnglobulīna G1 struktūras [The IMpact-RSV Study Group, 1998]. Palivizumabam, piesaistoties pie konservatīvā F proteīna epitopa A (aminoskābes; aa 258-275), piemīt neitralizējoša un vīrusa-šūnas saplūšanu inhibējoša darbība [Johnson et al., 1997]. Tā lietošana pašlaik tiek rekomendēta zīdaiņiem ar hemodinamiski nozīmīgu iedzimtu sirdskaiti, priekšlaicīgi dzimuša bērna hronisku plaušu slimību un bērniem, kas dzimuši pirms 35. gestācijas nedēḷas pirmajos dzīves mēnešos. Palivizumabu lieto intramuskulāri 3 līdz 5 devās ik 30 dienas, sākot no novembra līdz martam, atkarībā no lokālās HRSV sezonalitātes [American Academy of Pediatrics Committee on Infectious Diseases, 2009]. Efektivitāte ir pierādīta divos multicentru, placebo kontrolētos, randomizētos klīniskos pētījumos, kur tā lietošana samazināja hospitalizācijas biežumu par 45 un 55\%, kā arī hospitalizācijas un skābekḷa terapijas ilgumu, bet neietekmēja mirstību un nepieciešamību pēc mākslīgās plaušu ventilācijas [The IMpact-RSV Study Group, 1998; Feltes et al., 2003]. Šis preparāts Latvijā ir pieejams kopš 2009. gada, un tā lietošana lielā mērā balstīta uz citu Eiropas valstu pieredzi un epidemiologiskajiem datiem. Palivizumaba galvenais trūkums ir tā lielā dārdzība, un ir skaidrs, ka HRSV infekcijas slogu būtiski ierobežot varēs tikai vakcinācija, kuras izpēte jau ilgst vairāk kā 50 gadus. Lai ar̄i ir radīta virkne perspektīvu vakcīnu kandidātu, neviens no tiem šobrīd nav licencēts lietošanai [Anderson et al., 2013]. Vakcīnas, kas ir izgājušas I fāzes klīniskos pētījumus un kurām ir potenciāls tikt pārbaudītām II fāzēe, satur galvenokārt dzīvu atenuētu vīrusu vai vīrusa subvienības (attīrīti vai ekspresēti HRSV proteīni). Paralēli ir radīti vairāki atjautīgi vakcīnu dizaini, izmantojot vīrusu vektorus, gēnu vektorus un vīrusveidīgās daḷiņas, kuru pārbaude vēl kavējas I fāzes 
pētījumos. Būtiski, ka vakcīnas ieviešana ir ne tikai medicīniska nepieciešamība, tā būtu arī ekonomiski izdevīga [Meijboom et al., 2012].

\subsection{HRSV molekulārā epidemioloğija}

\subsubsection{HRSV galvenās antigēnās grupas}

Pēc reakcijas ar monoklonālajām antivielām pret vairākiem HRSV proteīniem, tā celmi tiek iedalīti divās galvenajās grupās, HRSV-A un HRSV-B [Mufson et al., 1985]. Šīs grupas atbilst ğenētiski atšķirīgiem vīrusiem, kas ir evolucionējuši nošķirti jau aptuveni 350 gadus [Zlateva et al., 2005]. Epidēmiskajās sezonās abas HRSV grupas populācijā cirkulē paralēli ar main̄̄gu prevalenci. Parasti vērojama cikliska dominantās grupas maiṇa, kur pēc vairākām secīgām HRSV-A dominantām sezonām seko viena HRSV-B dominanta sezona [Venter et al., 2001; Zlateva et al., 2007].

\subsubsection{HRSV genotipi}

Ievērojama HRSV mainība ir vērojama arī grupu ietvaros, un abās grupās cirkulējošie celmi tiek iedalīti vairākos genotipos. Vienlaicīgi sabiedrībā var cirkulēt dažādi genotipi, kurus sekojošās sezonās var nomainīt jauni, savukārt, iepriekš izplatīti genotipi izzust [Peret et al., 2000; Venter et al., 2001; Zlateva et al., 2007]. Vislielākās atšķirības gan starp abām grupām, gan grupu ietvaros ir atrodamas gēnā, kas kodē G proteīnu. Starp grupām G gēna identitāte ir 67\% nukleotīdu (nt) līmenī un 53\% aa līmen̄̄ [Johnson et al., 1987]. Genotipu klasifikācija, kas veidota, balstoties uz šī gēna nepilnu sekvenēšanu, pēdējos 15 gadus tiek plaši izmantota HRSV molekulārās epidemioloǵijas pētījumos. 1998. gadā Perē ar kolēgiem definēja HRSV genotipus pēc Ziemel̦amerikas izolātu filoǵenētisko koku topologijas, kas tika veidoti uz īsu (270 nt) 3' G gēna fragmentu pamata. Sākotnēji tika izdalīti pieci HRSV-A genotipi (GA1-5), starp kuriem atšksirības bija 10-28\% aa līmenī, un četri HRSV-B genotipi (GB1-4), starp kuriem bija 7-19\% aa atšķirības [Peret et 
al., 1998; Peret et al., 2000]. Gadu gaitā šĩ klasifikācija ir papildināta un šobrīd ir zināmi vismaz 11 HRSV-A genotipi: GA1-7 [Peret et al., 2000], SAA1 (Dienvidādrika ${ }^{3}$, A1) [Venter et al., 2001], kā arī nesenāki NA1 un 2 (Niigata ${ }^{4}, 1$ un 2) [Shobugawa et al., 2009] un ON1 (Ontario ${ }^{5}$, 1) [Eshaghi et al., 2012]. Savukārt HRSV B grupā izšķir vismaz 13 genotipus: GB1-4 (Peret et al., 1998], SAB1-3 [Venter et al., 2001] un BA-I-VI (Buenosairesa, I-VI) [Trento et al., 2006]. Pastāv arī zināmas atšķirības lietotajā nomenklatūrā dažādās laboratorijās. Tā piemēram, Keina ar kolēgiem ir izveidojusi HRSVA nomenklatūru, kur Birmingemas (Lielbritānijā) izolātu genotipi tiek numurēti A1-5 [Cane, 2001], un, lai arī šīs genētiskās līnijas atbilst Perē klasifikācijai, numerācija ir cita (piemēram, A5 atbilst GA1). Zlateva ar kolēgiiem HRSV-B izolātiem no Beḷgijas, kas atbilst BA ǵenētiskajām līnijām, lieto nosaukumu GB13 [Zlateva et al., 2005]. Vairāku citu strukturālo gēnu (N, F, SH), nekodējošo sekvenču un pilna genoma filoǵenētiskā analīze ir apstiprinājusi, ka mainība $\mathrm{G}$ gēnā atspoguḷo vispārējo vīrusa variabilitāti [Eshaghi et al., 2012; Gaunt et al., 2010; Rebuffo-Scheer et al., 2011; Sullender et al., 2000; Tan et al., 2012]. Jaunus genotipus pieņemts izdalīt, kad tie izpilda Venteres un kolēǵu ieteiktos kritērijus: (i) sākumpalaišanas ${ }^{6}$ vērtība tā zaram filoǵenētiskajā kokā ir $\geq 70 \%$ un (ii) genētiskā distance starp tā izolātiem ir $\leq 0,07$ [Venter et al., 2001].

HRSV lielā mainība dalēji izskaidro biežo reinfekciju skaitu visa cilvēka mūža laikā [Sullender, 2000]. Neitralizējošo antivielu atbilde ir grupu specifiska [Sande et al., 2013], un tā izzūd aptuveni 7-9 mēnešu laikā pēc infekcijas, bet celmu specifiskā imunitāte aptuveni 2-4 mēnešu laikā [Scott et al., 2006; Yamaguchi et al., 2011]. Viens un tas pats indivīds var atkārtoti slimot arī ar viena un tā paša genotipa izraisītām infekcijām [Houspie et al., 2013].

Dažādu genotipu klīniskās atšķirības varētu būt būtisks aspekts vakcīnas celmu izvēlē un individuālā pacienta prognozē. Dạ̧ā pêtîjumu ir konstatêta noteikta genotipa asociācija ar smagāku slimības gaitu [Hall et al., 1990; Hornsleth et al., 1998; Imaz et al., 2000; Martinello et al., 2002; Walsh et al., 1997], kamēr citos tāda nav atrasta [Kneyber et al., 1996; McIntosh et al., 1993; Wang et al., 1995].

\footnotetext{
${ }^{3}$ South Africa.

${ }^{4}$ Japānā.

${ }^{5}$ Kanādā.

${ }^{6}$ Bootstrap.
} 


\subsubsection{HRSV virsmas glikoproteīns $G$}

G ir II tipa transmembrānais glikoproteīns, kas ir 298 aa garš (references celmam A2). Ar HRSV inficētās šūnās tas tiek producēts divās formās - ar membrānu saistītā formā un šķ̄istošā formā, kas tiek sekretēta apkārtējā vidē un kura translācija tiek iniciēta ar alternatīvu iekšēju starta AUG kodonu [Roberts et al., 1994]. Virzienā no N- uz C-galu pilna garuma proteīnam izšķir trīs strukturālos domēnus: citoplazmatisko (aa 1-37), transmembrāno (aa 38-63) un lielu ektodomēnu (sākot no aa 64). Ektodomēns sastāv no diviem mucīnam līdzīgiem hipervariabliem reǵioniem (HVR1 un 2), kurus savā starpā atdala 13 pilnībā konservatīvu aa segments (references celma A2 aa pozīcijas 164-176), kas ir nemainīgs abās HRSV grupās [Johnson et al., 1987] (1.2. attēls). 


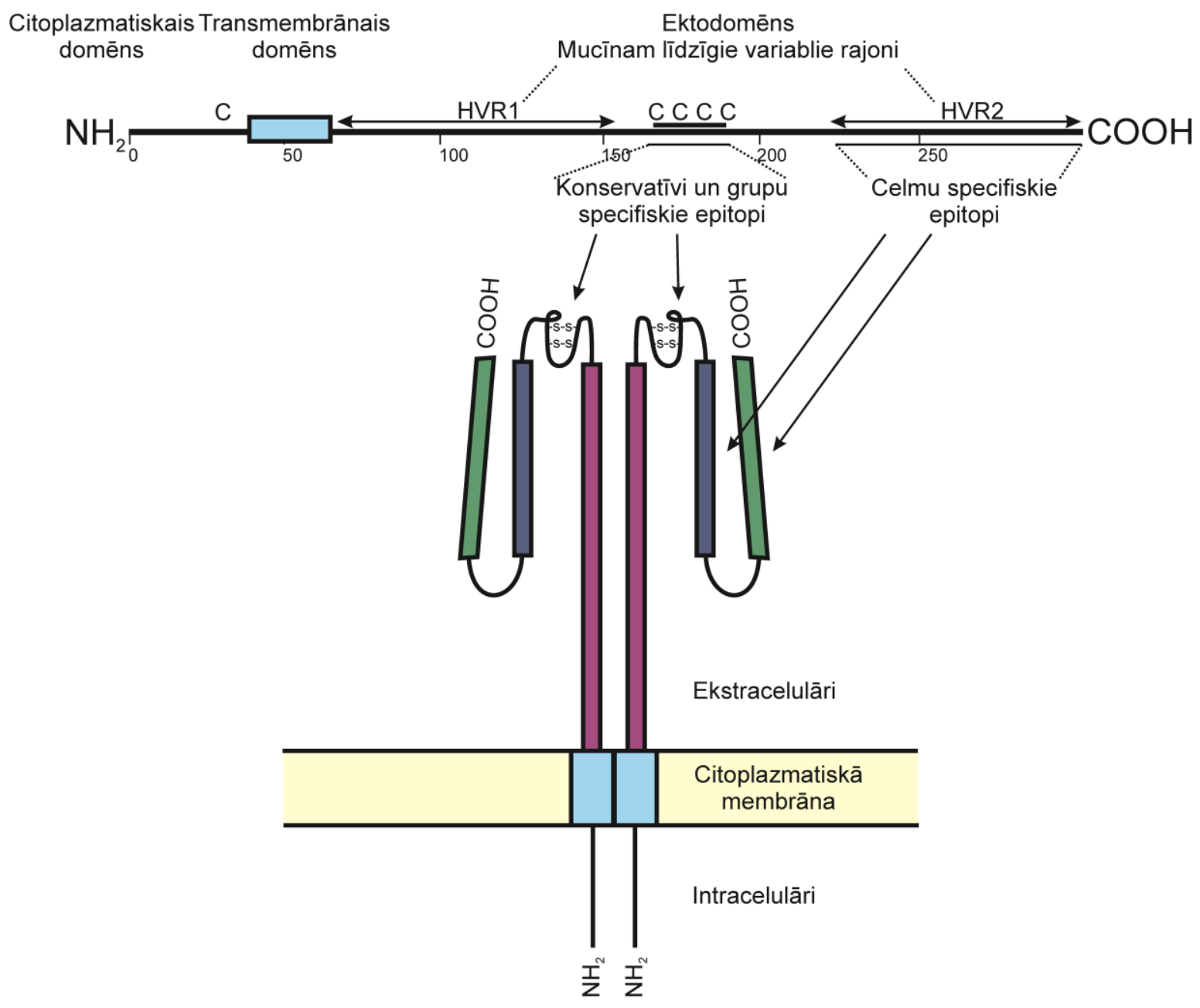

\section{2. att. HRSV G proteīna strukturālie un antigēnie domēni}

Atainota pilna garuma $\mathrm{G}$ proteīna shēma. $\mathrm{NH}_{2}$ un $\mathrm{COOH}$ attiecīgi norāda $\mathrm{N}$ - un C-galus. Zils taisnstūris norāda hidrofobo transmembrāno domēnu (aa 38 -63). HVR1 un 2 ir mucīnam līdzīgie hipervariablie reǵioni. $\operatorname{Ar}(\mathrm{C})$ apzīmēti cisteīnu atlikumi, centrālajā konservatīvajā rajonā četru cisteīnu sakopojums trīsdimensiju struktūrā veido divus disulfīda tiltiņus, t.s. cisteīnu cilpu, kas, iespējams, ir receptoru piesaistes vieta [Feldman et al., 1999]. Norādīta konservatīvo, grupu un celmu specifisko epitopu lokalizācija. Ar cipariem norādītas aminoskābju pozīcijas. Apakšèjā panelī atainota homodimēra trīsdimensionālās struktūras shēma. Attēls veidots pēc [Cane, 2001] un [Melero, 2007].

Sekvenču dažādība HVR segmentos ir viena no lielākajām, kāda novērota starp cilvēka vīrusiem, un ietver tādas nozīmīgas izmaiņas kā aa substitūcijas, delēcijas, insercijas, mutācijas ar rāmja nobīdi, lielas duplikācijas un priekšlaicīgus terminācijas kodonus. Šīs mutācijas atspoguḷo gan saimnieka organisma imūnās sistēmas radītu selekciju, gan apbrīnojamu proteīna strukturālo plasticitāti [Collins and Melero, 2011; Houspie et al., 2013; Trento et al., 2003; Zlateva et al., 2005]. Plašo mutāciju spektra rezultātā G proteīna garums var variēt no 215 līdz 321 aa [Eshaghi et al., 2012; Houspie et al., 2013]. Arī mutanti ar gandrīz pilnu G gēna delēciju ir izdalīti no imūnsupresētiem 
pacientiem [Venter et al., 2011]. Šādi vīrusi saglabā spēju replicēties in vitro un in vivo, bet ir pārāk atenuēti, lai replicētos vai izraisītu imūno atbildi imūnkompetentiem bērniem [Karron et al., 1997]. HVR segmenti satur vairākus celmu specifiskus epitopus, kuri ir lokalizēti, izmantojot peḷu monoklonālās antivielas un cilvēku rekonvalescences fāzes serumus [Cane, 2001]. Mucīnam līdzīgie reǵioni, tāpat kā eikariotiskie mucīni, ir bagāti ar serīna, treonīna un prolīna atlikumiem un ir izteikti glikozilēti ar O- un N-saites veidojošu og̣̦hidrātu ķēēēm. Glikozilācijas pozīciju skaits un vieta nav konservatīvi starp dažādiem celmiem, un to mainība pastiprina antigēnās atšksirības [Johnson et al., 1987; Martinez et al., 1997; Palomo et al., 1991].

\subsection{Evolūcijas analīzes metodes}

RNS vīrusu filoǵenētiskie pētījumi ir ērti pielietojami, jo to genomiem raksturīgas biežas mutācijas un nozīmīgas izmaiņas var tikt noteiktas vai atbilstoši aprēķinātas, izmantojot sekvences, kas iegūtas no salīdzinoši īsā laikā savāktiem klīniskajiem paraugiem. Filoǵenētiskā analīze sākas ar nukleīnskābju sekvenču iegūšanu un atbilstošu izkārtošanu, kas nozīmē, ka dažādas sekvences tiek izvietotas rindās viena virs otras tā, lai atbilstīgi nt veidotu vertikālu kolonnu. Atšķirīgām sekvencēm var atšķirties ne tikai nt (resp., substitūcijas), bet arī sastopamas insercijas vai delēcijas; šādos gadījumos, lai saglabātu izkārtojumu, ir nepieciešams ieviest spraugas. Bioinformātikas datorprogrammās tiek lietoti dažādi sekvenču izkārtošanas algoritmi, kas atšksiras ar „,sodu”, ko tās piešķir par spraugu ieviešanu. Populārākās brīvi pieejamās izkārtošanas datorprogrammas ir BioEdit [Hall, 1999] un ClustalW2 [Larkin et al., 2007]. Nākamais solis filoǵenētiskajā analīzē ir filoǵenētiskā koka konstruēšana, kas ir efektīvs veids, kā vizualizēt sekvenču genealoğiju. Kā ciltskokam tam ir sakne un zari, kas atiet no mezgliem, un to galos atrodas individuālie taksoni. Katrs mezgls atbilst kopīgam ciltstēvam $\left(\mathrm{MRCA}^{7}\right)$ un zari ap tiem var brīvi rotēt, nezaudējot interpretācijas nozīmi. Tas, cik tuva radniecība pastāv starp taksoniem vai zariem, parasti ir atainots horizontālajā as̄̄ (visbiežāk š̄̄ ass atbilst nt substitūciju skaitam pozīcijā). Attālumiem vertikālajā as̄i nav evolucionāras nozīmes un tie var tikt mainīti, lai

\footnotetext{
${ }^{7}$ Most recent common ancestor.
} 
padarītu koku uzskatāmāku. Filoǵenētisko koku var attēlot arī uz laika ass, ja ir zināms nt substitūciju ātrums pozīcijā, t.i. sekvences atbilst „molekulārajam pulkstenim”. Vienkāršākais molekulārā pulksteņa modelis ir pieņēmums, ka nt substitūcijas ātrums ir konstants laikā starp dažādām ǵenētiskajām līnijām. Tomēr bieži datu kopas labāk raksturo mazāk stingra jeb atslābināta molekulārā pulksteņa pieņēmums [skat. Lam et al., 2010 un atsauces šajā publikācijā]].

Pastāv divi galvenie veidi, kā noteikt evolucionārās attiecības starp dažādām sekvencēm: distanču un diskrētās (uz īpašību balstītas) metodes. Lietojot pirmo no tām, vispirms tiek aprēķinātas ǵenētiskās distances starp sekvencēm (t.i. tiek izveidota distanču matrica) un pēc tam, izmantojot šīs distances, tiek konstruēts filoǵenētiskais koks. Neighbor-joining (NJ) ir visbiežāk lietotā distanču metode. Tās pamatā ir filoǵenētiskā koka konstruēšana, klasterējot ǵenētiski vistuvāko sekvenču pārus („,kaimiṇus”) [Saitou and Nei, 1987]. NJ galvenā priekšrocība ir tās aprēksināšanas ātrums un tā neprasa lielus informāciju tehnoloǵiju resursus. Pretstatā distanču metodēm, diskrētās metodes izmanto pašas sekvences (nevis to ǵenētiskās distances). Maksimālās paticamības $\left(\mathrm{ML}^{8}\right)$ un Baijesa rekonstrukcijas metodes ir visbiežāk lietotās diskrētās metodes. Tā kā š̄is metodes pārbauda praktiski visus iespējamos kokus, tās ir lēnas un prasa lielus informāciju tehnolog̣iju resursus.

Infekcijas slimību izplatībā svarīgi ir gan ǵenētiskie, gan ekoloǵiskie faktori. Notiekot vīrusu transmisijai starp indivīdiem, notiek arī to pārvietošanās telpā, kur šie vīrusi tiek pakḷauti dažādu ekologisko faktoru spiedienam. Tā rezultātā ǵeogrāfiskā lokalizācija var atstāt izmērāmu ietekmi paraugu gēnu sekvencēs (t.s. ǵeogrāfiski strukturēti gēnu signāli). Pat vienas epidēmijas laiks ātri evolucionējošiem RNS vīrusiem ir pietiekošs, lai tie uzkrātu informatīvas mutācijas [Castro-Nallar et al., 2012; Holmes, 2008]. Tādējādi vīrusu sugu ietvaros gēnu ǵenealogijiju var izmantot, lai rekonstruētu demogrāfiskās un ǵeogrāfiskās izkliedes parametrus. Baijesa filoǵenētiskā rekonstrukcija izmanto Baijesa teorēmu, kur, ņemot vērā sākotnējo filoǵenēzes varbūtību un nosacījuma varbūtības (paticamības) parametrus tiek aprēķināta aposteriorā (jeb kopējā) koka varbūtība. Šim nolūkam tiek izmantots Markova ķēdes Montekarlo algoritms: nejauši tiek izraudzīts sākotnējais koks, uz kura bāzes tiek ǵenerēts jauns koks, izmantojot modeḷa parametrus.

\footnotetext{
${ }^{8}$ Maximum likelihood.
} 
Jaunais koks tiek pieņemts vai noraidīts, izmantojot speciālu iztveršanas ${ }^{9}$ procedūru. Ja jaunais koks tiek pieņemts, tas tiek modificēts tālāk, līdz to atkal nomaina cits koks. Šì ķēde tiek turpināta līdz analīzes rezultāti sasniedz stacionāru sadalījumu (bieži $>1 \times 10^{6}$ reižu). Lietojot Baijesa rekonstrukcijas metodes, atšķirībā no citām filoǵenētisko aprēķinu metodēm, pietiek zināt tikai nepieciešamo parametru varbūtības sadali [Lemey et al., 2009]; tās l̦auj veikt ciltstēvu rekonstrukciju (saplūšanu ${ }^{10}$ ), vienlaicīgi ņemot vērā to filoǵenētisko un ǵeogrāfisko nenoteiktību. Pēdējos gados, attīstoties gan sekvenēšanas tehnoloǵijām, gan informācijas apstrādes ātrumam, ir radītas vairākas datorprogrammas, kas izmanto šāasas varbūtības metodes, piemēram, BEAST, BAMBE un MrBayes.

Vēl viens būtisks vīrusu evolūcijas aspekts ir tās virziens. Mutācijas, kas rodas individuālā vīrusa genomā, stabilizāciju vīrusa populācijas mērogā nosaka dabīgā atlase, kas var būt gan pozitīva (jeb adaptīva, t.i. priekšrocīgu mutāciju atlasoša), gan negatīva (jeb attīroša, t.i. nevēlamu mutāciju iznīcinoša), bet, ja tās trūkst - neitrāla selekcija (konkrētā gēna evolūciju nosaka vien̄̄gi ǵenētiskais drifts). Nukleotīdu mutācijas proteīnu kodējošās genoma dạ̦ā var iedalīt kā sinonīmas $(d S)$ un ne-sinonīmas $(d N)$. Termins sinonīma mutācija nozīmē, ka kodējošās sekvences nt nomaiņas rezultātā nemainās aa sekvence. Turpretim, ne-sinonīma nt mutācija rada aa nomaiņu un tādējādi, mainot proteīna funkciju, atrodas zem selekcijas spiediena. Ja attiecīgais kodējošais reǵions atrodas zem pozitīva selekcijas spiediena, ne-sinonīmās $(d N)$ substitūcijas būs biežāk kā sinonīmās $(d S)$, t.i. $d N / d S>1$. Tā saucamās skaitīšanas un ML metodes tiek bieži izmantotas vīrusu evolūcijas pētījumos, lai noteiktu $d N / d S$ attiecību sekvenču datu kopā. Skaitīšanas metodes statistiski salīdzina iespējamo sinonīmo un ne-sinonīmo pozīciju skaitu ar reāli novērotajāàm substitūcijām sekvenču izkārtojumā. ML metodes piemēro kodonu substitūcijas modeli sekvenču datu kopai un aprēķina model̦a parametrus, maksimalizējot nosacījuma varbūtības funkciju. Šie aprēķini ir sarežḡîti un ir daudz lēnāki par skaitīšanas metodēm; izmantojot personālo datoru, tie nereti aizṇem dienas vai pat nedēļas, tādēl praktiski ir izmantot internetā pieejamus datoru klasteru servisus kā, piemēram, Datamonkey serveri (http://www.datamonkey.org/) [Delport et al., 2010]. Šajā interneta serverī ir pieejami vairāki skaitî̌sanas un ML algoritmi, no kuriem RNS vīrusu kodējošo sekvenču dabīgās

\footnotetext{
${ }^{9}$ Sampling.

${ }^{10}$ Coalescent theory.
} 
atlases analīzē bieži lietoti ir SLAC ${ }^{11}, \mathrm{FEL}^{12}, \mathrm{REL}^{13}$, IFEL ${ }^{14}$ un MEME ${ }^{15}$. Pirmās trīs no šīm metodēm ir dažādas ML metodes, kas l̦auj noteikt $d N / d S$ attiecību katrā kodonā filoǵenētiskā koka ārējos zaros. SLAC metode skaita $d N$ un $d S$ izmaiņas un pārbauda, vai $d N$ nozīmīgi atšķiras no $d S$. Algoritms apstrādā sekvenču izkārtojumu, izmantojot filoǵenētiskā koka zaru garumus, nt un kodonu substitūciju parametrus un senču sekvenču rekonstrukciju. FEL ir salīdzinoši jaunāka un statistiski precīzāka metode, kas atbilstoši kodonu substitūcijas modelim katrā pozīcijā neatkarīgi veic varbūtību attiecības testu, lai izvērtētu, vai modelis, kas pieņem $d N=d S$, var tikt atmests par labu modelim, kas pieņem $d N \neq d S$. REL metode piemēro kodonu substitūcijas modeli visam sekvenču izkārtojumam, bet piel̦auj $d N / d S$ attiecības variācijas starp pozīcijām. Salīdzinot ar REL, FEL metode retāk dod viltus pozitīvus rezultātus, kad tiek izmantotas mazas datu kopas [Kosakovsky Pond and Frost, 2005]. IFEL ir ML metode, kas l̦auj noteikt, vai sekvences, kas iegūtas no kādas populācijas daļas (piemēram, HRSV sekvences no dažādiem pacientiem), ir pakḷautas atlases spiedienam populācijas līmen̄̄ (starp filoǵenētiskā koka iekšējiem zariem) [Kosakovsky Pond et al., 2006]. MEME l̦auj izvērtēt gan paliekošas, gan epizodiskas pozitīvās selekcijas spiedienu. Š̄̄ metode mazina pieņēmumu, ka selekcijas spēks un virziens ir konstants, piel̦aujot $d N / d S$ variācijas starp pozīcijām, kā arī vienā pozīcijā dažādos filoǵenētiskā koka zaros [Murrell et al., 2012].

HRSV filodinamiskie aprēķini, balstoties uz HVR2 sekvenču ǵenealoǵiju, iepriekš ir labi sakrituši ar novērotajiem epidemioloǵiskajiem rezultātiem - salīdzinoši precīzi noteikuši vīrusa ǵenētisko līniju izcelšanās laiku, un aprēķinātais vīrusa populācijas izmērs ir bijis proporcionāls prevalences datiem [Houspie et al., 2013; Katzov-Eckert et al., 2013; Trento et al., 2010]. Piemēram, 1999. gadā tika konstatēts pirmais HRSV-B izolāts ar $60 \mathrm{nt}$ duplikāciju G gēnā [Trento et al., 2003]. Vīrusi ar šo mutāciju strauji izplatījās pa visu pasauli, tomēr vajadzēja paiet aptuveni 7 gadiem, lai tas aizstātu visas iepriekšèjās HRSVB līnijas. Šis laiks sakrita ar BA-IV celma populācijas strauju pieaugumu, un šobrīd tas ir gandrīz 100\% gadījumu izolētais HRSV-B genotips [Trento et al., 2010]. Jaunu patogenitātes faktoru izplatīšanās prognozēšana varētu l̦aut laicīgi plānot sabiedrības

\footnotetext{
${ }^{11}$ Single likelihood ancestor counting.

${ }^{12}$ Fixed effects likelihood.

${ }^{13}$ Random effects likelihood.

${ }^{14}$ Internal fixed effects likelihood.

${ }^{15}$ Mixed effects model of evolution.
} 
veselības stratēgijas, lai ierobežotu epidēmijas izplatību vai novērstu to. HRSV genotipi ļoti ātri izplatās plašos ǵeogrāfiskos reǵionos, un to celmi ir vairāk radniecīgi laikā (temporāli) nekā telpā (ǵeogrāfiski) [Peret et al., 2000; Trento et al., 2010], kas apgrūtina to analīzi [Katzov-Eckert et al., 2013], tomēr pastāv arī lokalizēti klasteri, kas ļauj rekonstruēt to filoǵeogrāfiju [Root et al., 2012]. 


\section{METODES}

2.1. tabula

\section{Pētījumā izmantotās aparatūras un materiālu saraksts}

\begin{tabular}{|c|c|c|}
\hline Darba etaps & Aparatūra & Materiāli/reaǵenti/datorprogrammas \\
\hline $\begin{array}{l}\text { Visiem darba } \\
\text { etapiem }\end{array}$ & $\begin{array}{l}\text { Kelvinators }\left(\text { Revco, }-70^{\circ} \mathrm{C}\right) \\
\text { centrifüga }(\text { Beckman } \\
\text { Microfuge } 11 ; \text { Eppendorf } \\
5415 \mathrm{R})\end{array}$ & $\begin{array}{l}\text { Mikropipetes (Eppendorf Research); } \\
\text { vienreizlietojamais materiāls: sterilas } \\
\text { mikromēǵenes, pipešu uzgaḷi }\end{array}$ \\
\hline $\begin{array}{l}\text { Klīnisko datu } \\
\text { vākšana }\end{array}$ & Pulsoksimetrs (Masimo SET) & Datorprogramma WHO Anthro v3.2.2 \\
\hline NFA iegūšana & $\begin{array}{l}\text { Aspirācijas sūknis (Vaccuson } \\
18, \text { Neuvag) }\end{array}$ & $\begin{array}{l}\text { Sterila, vienreizlietojama gḷotu savākšanas } \\
\text { sistēma (B Braun Trachea-secretion test set) }\end{array}$ \\
\hline RNS izolēšana & & QIAamp Viral RNA (QIAGEN) \\
\hline RT-PCR & Biociklizators (TC-S, Biosan) & $\begin{array}{l}\text { RevertAid }^{\mathrm{TM}} \text { Premium Reverse Transcriptase, } \\
\text { Taq DNA Polymerase, RiboLock }{ }^{\mathrm{TM}} \text { RNase } \\
\text { Inhibitor, dNTP mix (Fermentas); } \\
\text { amplifikācijas praimeri (Metabion) }\end{array}$ \\
\hline $\begin{array}{l}\text { Paraugu } \\
\text { elektroforēze } \\
\text { agarozes gēlā }\end{array}$ & $\begin{array}{l}\text { Strāvas avots (Consort E143); } \\
\text { ultravioletā starojuma avots un } \\
\text { gēlu dokumentēšanas iekārta } \\
\text { (UVP C-80 Epi-Illumination } \\
\text { UV Darkroom) }\end{array}$ & $\begin{array}{l}\text { GeneJET }^{\mathrm{TM}} \text { Gel Extraction reaǵentu kits, } \\
\text { TopVision LE GQ agaroze, GeneRuler } 1 \mathrm{kB} \\
\text { DNA ladder (Fermentas); etīdija bromīds, } \\
\text { datorprogramma paraugu vizualizēšanai UVP } \\
\text { Grab-IT }\end{array}$ \\
\hline $\begin{array}{l}\text { Klīnisko datu } \\
\text { statistiskā } \\
\text { apstrāde }\end{array}$ & & $\begin{array}{l}\text { Datorprogrammas: Microsoft Excel } 2010 \text { un } \\
\text { SPSS 17.0 }\end{array}$ \\
\hline Sekvenēšana & $\begin{array}{l}\text { Automātiskā DNS } \\
\text { sekvenēšanas sistēma (ABI } \\
\text { PRISM, Applied Biosystems) }\end{array}$ & $\begin{array}{l}\text { BigDye }{ }^{\circledR} \text { Terminator Cycle Sequencing Kit } \\
\text { (Applied Biosystems), sekvenēšanas praimeri } \\
\text { (Metabion), molekulāro datu apstrādes } \\
\text { datorprogramma Vector NTI Advance } 10 \\
\text { (Invitrogen) }\end{array}$ \\
\hline Bioinformātika & & $\begin{array}{l}\text { Datorprogrammas: Clustal W2 Multiple Sequence } \\
\text { Alignment tool, MEGA v5.1, DNAsp v5, } \\
\text { DAMBE v5.3.32, NetOGlyc v3.1 un NetNGlyc } \\
\text { v1.0 serveri, Datamonkey serveris, Path-O-Gen } \\
\text { v1.4, BEAST v2.0.2, SPREAD v1.0.6 }\end{array}$ \\
\hline Datu vizualizācija & & $\begin{array}{l}\text { Datorprogrammas: ESRI ArcMap 10.1, } \\
\text { CorelDRAW x6 }\end{array}$ \\
\hline
\end{tabular}




\subsection{Pētījuma populācija}

Šis prospektīvais kohortas pêtījums tika veikts Valsts sabiedrībā ar ierobežotu atbildību „Bērnu klīniskā universitātes slimnīca” Torņakalna novietnē (BKUS) laika posmā no 2009. gada 1. jūlija līdz 2012. gada 30. jūnijam. Pētijums saņēma Rīgas Stradiña universitātes Ėtikas komitejas aţ̦auju, un informētu piekrišanu dalībai tajā parakstīja visu iekḷauto pacientu vecāki (skat. 1. pielikumu). Par iekḷaušanas kritērijiem kalpoja: (1) bērna vecums, 2-24 mēneši, un (2) atbilstîba PVO dziḷāko elpceļu infekcijas gadījuma definīcijai (2.1. attēls) [Wright and Cutts, 2000]. Lai izvairītos no iespējamiem jaucējfaktoriem, par izslēgšanas kritērijiem tika noteikti: (1) hroniskas pavadošas centrālās nervu sistēmas un kardiopulmonālas slimības un (2) pacienti, kuru simptomi bija ilgāki par 10 dienām.

\begin{tabular}{ccc}
\hline 2-11 mēn. & \multicolumn{1}{c}{$12-24$ mēn. } \\
\hline Ātra elpošana, $\geq 50$ reižu minūtē & $\bar{A}$ tra elpošana, $\geq 40$ reižu minūtē \\
Krūškurvja retrakcijas \\
VAI \\
Stridors mierīgam bērnam \\
VAI \\
Sékšana \\
VAI \\
Apnoja
\end{tabular}

\section{1. att. PVO dziḷāko elpceḷu infekcijas klīniskā diagnostikas shēma}

Pacientu sūdzības, antropometriskie rādītāji, anamnēzes dati, objektīvā izmeklēšana, pulsoksimetra rādīiāji, laboratorā atrade, radioloǵiskās izmaiņas, saņemtā terapija un hospitalizācijas ilgums tika atzīmēti standartizētā protokolā. Lai salīdzinātu dažādu vecumu bērnu antropometriskos rādītājus, tie tika standartizēti ar vecumam atbilstošām $z$-vêrtībām, $\begin{array}{llll}\text { izmantojot datorprogrammu } & \text { WHO } & \text { Anthro }\end{array}$ (http://www.who.int/childgrowth/software/en/). Klīniskie dati tika objektivizēti, izmantojot punktu skalas. Respiratorā distresa novērtēšanas instruments (RDNI) gradē elpošanas mazspēju no 0-17 un tiek plaši izmantots klīniskajos pētījumos (2.2. tabula) [American Academy of Pediatrics Subcommittee on Diagnosis and Management of Bronchiolitis, 
2006; Lowell et al., 1987]. Adaptēta Klīniskā smaguma skala (KSS) novērtēja slimības smagumu no 0 līdz 6 punktiem: mākslīgā plaušu ventilācija - 2 punkti; stacionēšana, hospitalizācija $\geq 5$ dienām, arteriālā skābekḷa saturācija $\leq 87 \%$, skābekḷa terapija - katrs pa vienam punktam [Martinello et al., 2002]. Tika vērtēta pacientu atbilstība sistēmiskā iekaisuma atbildes sindroma (SIRS) kritērijiem [Goldstein et al., 2005].

2.2. tabula

Respiratorā distresa novērtēšanas instruments [Lowell et al., 1987]

\begin{tabular}{|c|c|c|c|c|c|c|}
\hline & \multicolumn{5}{|c|}{ Punkti } & \multirow{2}{*}{ Maks. } \\
\hline & 0 & 1 & 2 & 3 & 4 & \\
\hline \multicolumn{7}{|l|}{ Sēkšana } \\
\hline Ekspiratora & Nav & Beigās & $1 / 2$ & $3 / 4$ & Pilna & 4 \\
\hline Inspiratora & Nav & Daļēja & Pilna & & & 2 \\
\hline Lokalizācija & $\mathrm{Nav}$ & Segmentāra $^{a}$ & Difūza $^{b}$ & & & 2 \\
\hline \multicolumn{7}{|l|}{ Retrakcijas } \\
\hline Supraklavikulāras & Nav & Viegla & Vidēja & Ievērojama & & 3 \\
\hline Interkostālas & $\mathrm{Nav}$ & Viegla & Vidēja & Ievērojama & & 3 \\
\hline \multirow[t]{2}{*}{ Subkostālas } & $\mathrm{Nav}$ & Viegla & Vidēja & Ievērojama & & 3 \\
\hline & & & & & Kopā: & 17 \\
\hline
\end{tabular}

${ }^{a} \leq 2$ no 4 plaušu laukiem

${ }^{b} \geq 3$ no 4 plaušu laukiem

\subsection{Klīniskie paraugi}

No katra pêtījumā iekḷautā pacienta tika iegūts nazofaringeālais aspirāts (NFA). Caur deguna eju aizdegunē (dziļumā atbilstoši attālumam no deguna atveres līdz auss tragus) tika ievadīts sterils 8 Fr atsūkšanas katetrs. Aspirāts tika savākts ar Tracheasecretion test set sistēmu (B. Braun Melsungen AG), pielietojot 100-200 mBar negatīva spiediena katetra izvilkšanas laikā ( $10 \mathrm{~s})$. Lai nepazaudētu katetrā atlikušo materiālu, tas tika izskalots ar $2 \mathrm{ml} \mathrm{0,9 \%} \mathrm{NaCl}$ šksīduma. NFA paraugi tika nekavējoties iesaldēti un uzglabāti pie $-70^{\circ} \mathrm{C}$ līdz turpmākai analīzei.

Kopējā RNS tika izolēta no $140 \mu \mathrm{l}$ NFA parauga, izmantojot komerciālu RNS izolēšanas kitu (QIAamp Viral RNA, QIAGEN) saskaņā ar ražotāja rekomendācijām. 
Izdalītā RNS tika izšks̄īināta $60 \mu \mathrm{l}$ AVE buferšķı̄dumā (QIAGEN) un atkal iesaldēta pie $70^{\circ} \mathrm{C}$. Izdalītā RNS kalpoja par matricu HRSV molekulārās diagnostikas testu izstrādei.

Daļai pacientu tika ņemta arī rutīnas deguna iztriepe (ārpus pētîjuma protokola pēc ārstējošā ārsta ieskatiem). Deguna iztriepē tika noteikta HRSV, adenovīrusa, gripas vīrusu A un B, paragripas vīrusu 1-3 un cilvēka metapneimovīrusa antigēnu klātbūtne ar kvalitatīvu netiešo imūnfluorescences testu (IFA) SIA „Rīgas Austrumu klīniskā universitātes slimnīca” stacionāra „Latvijas Infektologijas centrs” (LIC) laboratorijā (IMAGENTM Respiratory screen kit, Oxoid). Pētījuma laikā tā bija standartmetode respiratoro vīrusu diagnostikai BKUS.

\subsection{HRSV diagnostika, grupu diferencēšana, sekvenēšana}

\subsection{1. cDNS sintēze}

HRSV specifiskā cDNS tika sintezēta ar RT-PCR, izmantojot RevertAid ${ }^{\mathrm{TM}}$ Premium apgriezto transkriptāzi (Fermentas) ar 12,5 $\mu \mathrm{L}$ izdalītās RNS un 20 pmol praimeri F164_Rv (skat. 2.3. tabulu). cDNS sintēze notika $30 \mathrm{~min} 50^{\circ} \mathrm{C}$, reakcija tika pārtraukta, karsējot $5 \min 85^{\circ} \mathrm{C}$. 


\section{Oligonukleotīdu* praimeri HRSV molekulārajai analīzei}

\begin{tabular}{|c|c|c|c|c|}
\hline Praimeris un mērķis & Gēns & S Pozīcija & Sekvence $\left(5^{\prime} \rightarrow 3^{\prime}\right)$ & Atsauce \\
\hline \multicolumn{5}{|c|}{ cDNA sintēze } \\
\hline F164_Rv & $\mathrm{F}$ & $173-151^{a}$ & GTTATRACACTRGTATACCAACC & $\begin{array}{c}\text { [Sullender et al. } \\
\text { 1993] }\end{array}$ \\
\hline \multicolumn{5}{|l|}{ HRSV diagnostika } \\
\hline P_Fw & $\mathrm{P}$ & $452-475^{a}$ & CATTAGTAGTTGCAAGTGCAGGAC & Šis pētījums \\
\hline M_Rv & M & $46-25^{a}$ & CTGTGTATGTGGAGCCTTCGTG & Šis pētījums \\
\hline
\end{tabular}

\section{Grupu diferencēšana}

\begin{tabular}{|c|c|c|c|c|}
\hline Ga_Fw & $\mathrm{G}$ & $522-542^{a}$ & CATATGCAGCAACAATCCAAC & Šis pētījums \\
\hline Gb_Fw & $\mathrm{G}$ & $328-347^{b}$ & CCAATCCACACAAATTCAGC & Šis pētījums \\
\hline F_Rv & $\mathrm{F}$ & $6-(-15)^{a}$ & CTCCATTGTTATTTGCCCCAG & $\begin{array}{c}\text { [Peret et al., } \\
1998]\end{array}$ \\
\hline
\end{tabular}

A grupas G gēna 5' gala amplifikācija

$\begin{array}{lcccc}\text { RSVa_preG3_Fw } & \text { G } & (-59)- & \text { TAGTCATAACAATGAACTAGGAT } & \text { Šis pētījums } \\ \text { RsGa_Rv } & \text { G } & 548-527^{a} & \text { CAGCAGGTTGGATTGTTGCTG } & \text { Šis pētījums }\end{array}$

B grupas G gēna 5' gala amplifikācija

\begin{tabular}{lcccc} 
RSVb_preG_Fw & G & $\begin{array}{c}(-95)- \\
(-74)^{b}\end{array}$ & CAACTATCATGGTAGCATAGAG & Šis pētījums \\
RsGb_Rv & G & $533-514^{b}$ & GTTGCCACATATACTACAGG & Šis pētījums \\
\hline
\end{tabular}

* Visi oligonukleotīdi, kas izmantoti šajā pētījumā, tika sintezēti Metabion

Nukleotīdu pozīcijas norādītas balstoties uz numerāciju HRSV prototipu celmos:

${ }^{a}$ A2 (GenBank pieejas kods M74568) [Wertz et al., 1985]

${ }^{\mathrm{b}} \mathrm{B} 1$ (GenBank pieejas kods AF013254) [Karron et al., 1997]

\subsubsection{HRSV diagnostika un grupu diferencēšana}

Pirmkārt, HRSV specifiskās RNS klātbūtne tika detektēta ar PCR, amplificējot ǵenētiski konservatīvu genoma rajonu starp P un M gēniem, neatkarīgi no vīrusa antigēnās grupas (2.3. tabula, 3.1. attēls). Tālāk pozitīvajiem paraugiem tika noteikta piederība galvenajām grupām, HRSV-A un B, veicot grupu specifisku PCR G gēna HVR2 segmentam. Apgrieztais praimeris F_Rv bija kop̄̄gs abām grupām, bet tiešie praimeri bija grupu specifiski: Ga_Fw A grupai un Gb_Fw B grupai (2.3. tabula). PCR tika veikta TC-S biociklizatorā (Thermal Cycler, BioSan) ar Taq DNS polimerāzi (Fermentas) 2 min pie 
$94^{\circ} \mathrm{C}$, kam sekoja 40 cikli ar denaturāciju $30 \mathrm{~s}$ pie $94^{\circ} \mathrm{C}$, salipšanu $30 \mathrm{~s}$ pie $55^{\circ} \mathrm{C}$ un amplifikāciju $1 \mathrm{~min}$ pie $72^{\circ} \mathrm{C}$. Amplificētie fragmenti tika analizēti elektroforētiski ar etīdija bromīdu krāsotā 1\% agarozes gēlā.

\subsubsection{DNS sekvenēšana}

Grupu diferencēšanas PCR produkti tika izdalīti no agarozes gēla ar GeneJET ${ }^{\mathrm{TM}}$ ekstrakcijas kitu (Fermentas). Attīrītie DNS fragmenti tika sekvenēti, izmantojot apgriezto praimeri F_Rv un tiešos praimerus Ga_Fw (HRSV-A) un Gb_Fw (HRSV-B), ABI PRISM 3130x1 ǵenētiskajā analizatorā (Applied Biosystems) ar BigDye ${ }^{\circledR}$ Terminator Cycle Sequencing Kit (Applied Biosystems). Šādā veidā pēc datu apstrādes tika iegūtas 336 nt garas HRSV-A (kodonu pozīcijas 187-299 atbilstoši references celma A2 sekvencei) un 516 nt garas HRSV-B (kodonu pozīcijas 140-293 atbilstoši references celma B1 sekvencei) sekvences. 2010./2011. un 2011./2012. sezonu unikālās sekvences tika reǵistrētas GenBank datu bāze ar pieejas kodiem no KF030137 līdz KF030185. Papildus tam 2009./2010. sezonas izolātiem tika amplificēts arī G gēna 5' gals, izmantojot RSVa_preG3_Fw un RsGa_Rv vai RSVb_preG_Fw un RsGb_Rv praimerus attiecīgi A un B grupai (2.3. tabula). Šie fragmenti tāpat kā iepriekš tika izdalīti no agarozes gēla un sekvenēti, izmantojot tiešos praimerus RSVa_preG3_Fw un RSVb_preG_Fw atbilstoši grupai. Tādējādi tika iegūtas pilnas $\mathrm{G}$ gēna sekvences, kas tika reǵistrētas GenBank datu bāze ar pieejas kodiem no JF979145 līdz JF979157.

\subsection{Filoğenēzes un adaptīvās evolūcijas analīze}

\subsubsection{Filoǵenētiskā analīze}

Pētījumā iegūtās HRSV nt un deducēto aa (lietojot universālo ǵenētisko kodu) sekvences tika izkārtotas kopā ar iepriekš publicētām sekvencēm, kas pieejamas GenBank (http://www.ncbi.nlm.nih.gov/genbank/). Sekvenču izkārtošana tika veikta ar EMBL-EBI 
ClustalW2 Multiple Sequence Alignment rīku [Larkin et al., 2007]. Identiskās nt un aa sekvences tika identificētas, lietojot datorprogrammu DAMBE16 v5.3.32 (http://dambe.bio.uottawa.ca/dambe.asp). Filoğenētiskie koki tika konstruēti ar NJ algoritmu [Saitou and Nei, 1987], un genētiskās distances (vidējais nt un aa substitūciju skaits katrā novietojumā starp visiem sekvenču pāriem) tika aprēķinātas, izmantojot piemērotāko substitūcijas modeli datorprogrammā MEGA v5.1 ${ }^{17}$ [Tamura et al., 2001]. Aprēķinu statistiskā nozīmība tika pārbaudīta ar sākumpalaišanas protokolu, izmantojot 1000 kopijas. Nukleotīdu polimorfisms (vidējais nt nomaiņu skaits novietojumā; $\pi$ ) tika aprēķināts, izmantojot datorprogrammu DNAsp v $5^{18}$ [Librado and Rozas, 2009].

\subsubsection{Glikozilācijas vietu prognozēšana}

$O$-glikozilācijas pozīcijas tika noteiktas, izmantojot NetOGlyc 3.1 servera neirālā tīkla prognozes (http://www.cbs.dtu.dk/services/NetOGlyc/), un $\mathrm{G}$ vērtība $>0,5$ tika izmantota kā sliekšņa vērtîba [Julenius et al., 2005]. Konsensa motīva asparagīns-Xserīns/treonīns (N-X-S/T), kur X ir jebkura aminoskābe, izņemot prolīnu [Hart, 1992], Nglikozilācija tika prognozēta, $\mathrm{kad}$ NetNGlyc $1.0 \quad$ servera (http://www.cbs.dtu.dk/services/NetNGlyc/) glikozilācijas potenciāls bija $>0,5$ [Gupta et al., 2004].

\subsubsection{Dabīgā atlase}

Kodoni, kuri atrodas zem pozitīvās selekcijas spiediena, tika noteikti ar katrai pozīcijai specifisku $d N / d S$ attiecību, izmantojot piecus dažādus algoritmus, kas pieejami Datamonkey serverī (http://www.datamonkey.org/) [Delport et al., 2010]: SLAC, FEL, REL, IFEL un MEME. Piemērotākais substitūcijas modelis tika izvēlēts, izmantojot datorprogrammu MEGA v5.1. Tika pieņemts, ka kodons atrodas zem pozitīvas selekcijas

\footnotetext{
${ }^{16}$ Data Analysis in Molecular Biology and Evolution.

${ }^{17}$ Molecular Evolutionary Genetics Analysis.

${ }^{18}$ DNA Sequence Polymorphism.
} 
selekcijas spiediena, kad divas vai vairāk metodes tā pozīcijā aprēķināja $d N / d S>1$ ar statistisku nozīmību ( $\mathrm{p}<0,1$ vai Baijesa faktors >20) kā to rekomendē [Kosakovsky Pond et al., 2005]. Vidējā $d N / d S$ attiecība tika noteikta, izmantojot SLAC algoritmu. Analogi gēnu fragmenti (t.i. referenču celmu A2 un B1 kodonu pozīcijas no 187 līdz Stop) tika lietoti visos gadījumos, kad abas HRSV grupas tika savstarpēji salīdzinātas.

\subsection{Evolūcijas ātrums, populācijas dinamika un filoğeogrāfiskā analīze}

Lai pārbaudītu, vai nt sekvenču dati uzrāda novirzi laikā (t.i. pārbaudīt molekulārā pulksteņa hipotēzi), tika veikta ǵenētisko distanču novirzes lineārās regresijas analīze kā izolēšanas laika funkcija, izmantojot datorprogrammu Path-O-Gen v1.4 [Drummond et al., 2003]. Ģenētiskās distances tika iegūtas, konstruējot ML filoǵenētisko koku ar datu kopai vislabāk atbilstošo nt substitūcijas modeli datorprogrammā MEGA v5.1. Iegūto datu statistiskā pārbaude un vizualizācija tika veikta, izmantojot datorprogrammu Microsoft Excel 2010. Precīzs izolēšanas datums bija zināms visām sekvencēm, kas tika izmantotas analīzē, un tas tika izteikts kā gads ar vienu decimālzīmi aiz komata. Nukleotīdu substitūcijas ātrums, kopīgā ciltstēva laiks (tMRCA) ${ }^{19}$, vīrusa populācijas apjoma izmainas un diskrētā filoǵeogrāfiskā analīze tikai aprēķināti, ar laiku un lokalizāciju iezīmētām sekvencēm pielietojot Baijesa Markova ķēes Montekarlo $(\mathrm{MCMC})^{20}$ metodi datorprogrammā BEAST ${ }^{21}$ v2.0.2 [Drummond et al., 2012]. Dati tika analizēti, pieņemot atslābinātu (pēc normāla logaritmiskā sadalījuma) molekulāro pulksteni, kas piel̦auj nt substitūciju biežumu variācijas starp genētiskajām līnijām, un lietojot Baijesa apvāršņa demogrāfisko modeli kā saplūšanas sākotnējo varbūtîbu. MCMC ķēžu garums tika izvēlēts, lai efektīvās paraugkopas lielums būtu $>200$. MCMC analīzes rezultāti tika izvērtēti, izmantojot datorprogrammu Tracer v1.5, un maksimālās radniecības ticamības (MCC) ${ }^{22}$ filoǵenētiskais koks tika konstruēts, izmantojot datorprogrammu TreeAnnotator v2.0.2. MCC koks tika vizualizēts, izmantojot datorprogrammu FigTree v1.4.0. Diskrētās

\footnotetext{
19 Time of most recent common ancestor.

${ }^{20}$ Markov chain Monte Carlo.

${ }^{21}$ Bayesian evolutionary analysis sampling trees.

${ }^{22}$ Maximum Clade Credibility.
} 
filoǵeogrāfiskās analīzes kopsavilkums difūzijas dinamiskajā diagrammā un interaktīvā animācijā tika radīti, izmantojot datorprogrammu SPREAD v1.0.6 ${ }^{23}$ [Bielejec et al., 2011], un vizualizēti, izmantojot geoogrāfisko informācijas sistēmu ESRI ArcMap 10.1. Datu nenoteiktība tika izteikta kā 95\% augstākās varbūtības blīvums, HPD $^{24}$.

\subsection{Datu statistiskā apstrāde}

\subsubsection{HRSV sezonalitātes datu statistiskā apstrāde}

Pētijjumā viena respiratoro infekciju sezona tika definēta kā laika periods no 1. jūlija līdz nākamā gada 30. jūnijam. HRSV epidemiolog̣iskās aktivitātes periods, modificējot plaši lietotu definīciju, tika noteikts kā laika posms starp pirmo no divām secīgām nedẹlām, kurās $\geq 10 \%$ testēto paraugu ir HRSV pozit̄ivi, un pēdējo no divām secīgām nedēlāam, kurās $\geq 10 \%$ testēto paraugu ir HRSV pozitīvi, analizējot summāros trīs sezonu pacientu sadalījuma datus [Mullins et al., 2003; Panozzo et al., 2010; Terletskaia-Ladwig et al., 2005]. Paraugu sadalījumam pa nedẹlāam tika aprēķināta moda, mediāna un vidējais lielums ar standartnovirzi (SD). Tā kā respiratoro vīrusu sezonas šķērso gadu miju, šo datu aprēķinos gada nedēlas no 1-26 tika izteikti kā pozitīvi lielumi, bet nedēḷas no 27-52 kā negatīvi, t.i. nedēḷas kārtas skaitlim atņemot 52. 2009. gadā bija 53 nedēļas, šajā gadījuma 53. nedēlas dati tika pieskaitīti 52. nedēļas datiem. Lai izslēgtu datu vākšanas ietekmi uz sezonalitātes datiem, pieļaujot, ka vairāku vīrusu epidemioloǵiskā aktivitātes periodi var sakrist, tika pārbaudīta Pīrsona korelācija starp HRSV pozitīvo un negatīvo paraugu sadalījumiem pa nedẹlāām. Visi dati tika analizēti, izmantojot datorprogrammu Microsoft Excel 2010.

\footnotetext{
${ }^{23}$ Spatial Phylogenetics Reconstruction of Evolutionary Dynamics.

${ }^{24}$ Highest probability density.
} 


\subsubsection{Klīnisko datu statistiskā apstrāde}

Klīnisko datu statistiskai apstrādei tika izmantota datorprogrammas $\operatorname{SPSS}^{25} 17.0$ un Microsoft Excel 2010. Intervālu un rangu skalas dati tika salīdzināti, izmantojot MannaVitnija testu, un aprakstīti, izmantojot mediānu vai modu, kā arī norādot izkliedes intervālus. Nominālie dati tika salīdzināti, izmantojot Pīrsona $\chi^{2}$ vai Fišera testu, un atainoti kā pacientu skaits un daļa, izteikta procentos. Atšķirības tika uzskatītas par statistiski nozīmīgām, ja $\mathrm{p}<0,05$.

\footnotetext{
${ }^{25}$ Statistical Package for Social Sciences.
} 


\section{REZULTĀTI}

\subsection{HRSV klīniskais raksturojums}

\subsubsection{Pētījuma pamatgrupa}

Pacientu iekḷaušana pētījuma pamatgrupā tika uzsākta 2009. gada 1. jūlijā un noslēdzās 2012. gada 30. jūnijā, respektīvi, iegūtie dati pārstāv trīs respiratoro infekciju sezonas. Kopumā pētījumā tika iekḷauti 207 pacienti (67-71 pacienti sezonā). Pacientu vecuma mediāna bija 8 (starpkvartịlu izkliede 4-14) mēneši, no tiem 36\% bija vecumā līdz 6 mēnešiem un kopā 68\% vecumā līdz 12 mēnešiem. Vairākums no pacientiem tika uzņemti akūtās pediatriskās aprūpes nodaḷās, bet seši (3\%) intensīvās terapijas nodaḷā. Seši pacienti (3\%) tika pētījumā iekl̦auti atkārtoti. Katra pacienta paraugam tika piešķirts kods pēc sekojošas shēmas: LV (Latvija)/parauga numurs pēc kārtas attiecīgajā gadā/parauga ņemšanas gads.

\subsubsection{HRSV diagnostika un grupu diferencēšana}

Balstoties uz GenBank datubāzē publicētajām HRSV genoma sekvencēm, kā arī līdzīgu pētījumu pieredzi citās pasaules laboratorijās [Peret et al., 1998; Sullender et al., 1993], tika konstruēta virkne sintētisku oligonukleotīdu (praimeru) (2.3. tabula). PCR diagnostikas stratēgija parādīta 3.1. attēlā. Veicot primāro skrīningu, 509 bp PCR fragments bija viegli detektējams agarozes gēlā. Šādā veidā HRSV specifiskas RNS klātbūtne tika noteikta $88(42,5 \%)$ no 207 pārbaudītajiem paraugiem. Nevienam no atkārtoti pētîjumā iekl̦autajiem pacientiem netika konstatēta HRSV reinfekcija.

Veicot HRSV grupu diferencēšanu, praimeri tika konstruēti tā, lai HRSV-A un B varētu viegli izšķirit pēc amplificētā fragmenta garuma (3.1. attēls). Šādi tika pārbaudīti visi 88 HRSV-pozitīvie paraugi; 53 (60,2\%) uzrādīja A grupai un 35 (39,8\%) B grupai atbilstošu fragmenta garumu. Nevienā gadījumā netika konstatēta abu grupu ko-infekcija. 


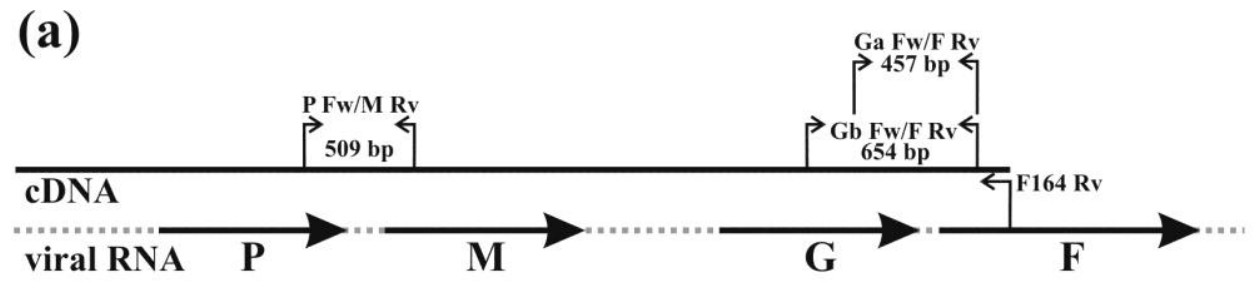

(b)

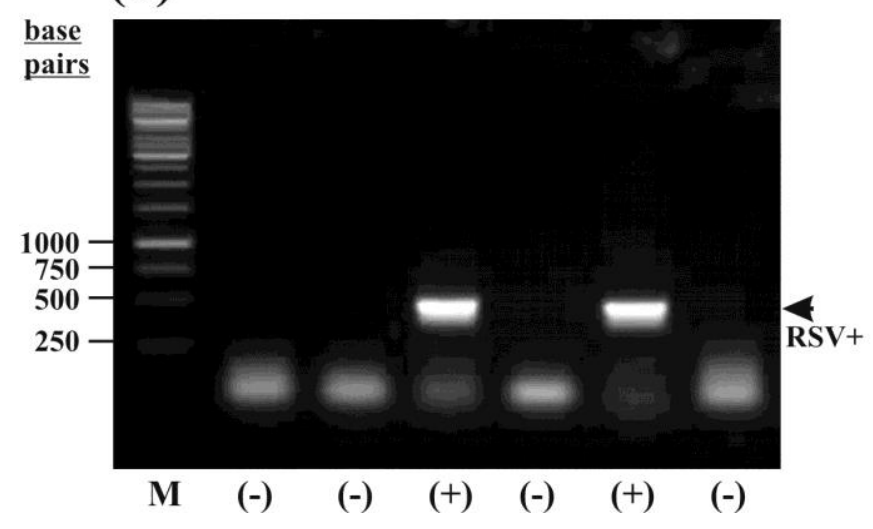

(c)

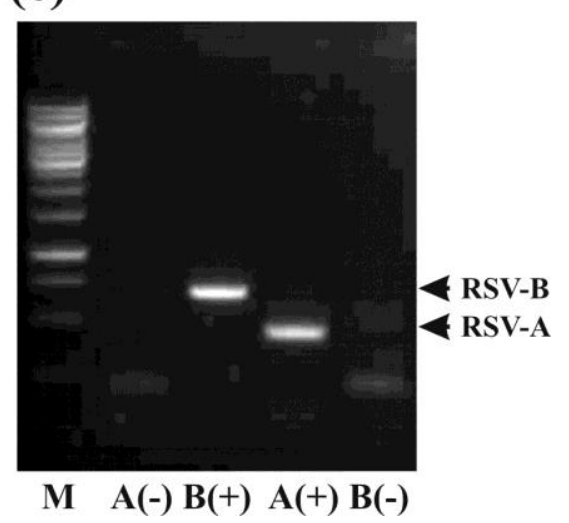

\section{1. att. HRSV molekulārās diagnostikas stratēǵija}

A, shematiski attēlota daḷa no HRSV genoma un PCR diagnostikas stratēgija; B un C, agarozes gēla elektroforēze, kas ilustrē primāro HRSV skrīningu ar praimeriem P_Fw/M_Rv (B) un HRSV pozitīvo paraugu grupu diferencēšanu (C). M, DNS molekulārās masas marķierīis (Fermentas); $(+)$ pozitīva reakcija; $(-)$ negatīva reakcija.

Paralēli PCR analīzei, 110 pacientiem tika ņemtas arī deguna iztriepes virusoloǵiskajai diagnostikai ar IFA. Šis izmeklējums neietilpa pētījuma programmā un tika veikts pēc ārstējošā ārsta ieskatiem. Šajā grupā HRSV tika diagnosticēts $40 \quad(36,4 \%)$ pacientiem, paragripas vīruss $9(8,2 \%)$, metapneimovīruss $6(5,5 \%)$, gripas A vīruss (t. sk. H1N1) $3(2,7 \%)$, kā arī pa vienam adenovīrusa un gripas B vīrusa gadījumam $(0,9 \%)$. Pētījumā izstrādātā metode spēja detektēt HRSV infekciju sešos IFA-negatīvos paraugos, savukārt, tā nespēja detektēt HRSV divos IFA pozitīvos paraugos. Salīizinot RT-PCR ar IFA kā "zelta standartu" $2 \times 2$ diagnostisko testu salīdzināšanas tabulā (3.1. tabula), tika iegūta jutība - 95,2\%, specifiskums - 91,2\%, pozitīvā paredzamā vērtība - 87\% un negatīvā paredzamā vērtība - 97\% [Feinstein, 2002].

Pieciem (6\%) pacientiem ar HRSV infekciju tika noteikta koinfekcija ar citu vīrusu - diviem ar gripas A, diviem ar gripas B un vienam ar cilvēka metapneimovīrusu. 
IFA un RT-PCR metožu salīdzinājums HRSV diagnostikā

\begin{tabular}{ccccc}
\hline & & \multicolumn{3}{c}{ IFA } \\
\cline { 3 - 5 } & & Pozitīvs & Negatīvs & Kopā \\
\hline \multirow{3}{*}{ RT-PCR } & Pozitīivs & 40 & 6 & 46 \\
& Negatīvs & 2 & 62 & 64 \\
& Kopā & 42 & 68 & 110 \\
\hline
\end{tabular}

RT-PCR - apgrieztās transkripcijas PCR; IFA - netiešās imūnfluorescences tests.

\subsubsection{HRSV sezonalitāte}

Kopējā HRSV-pozitīvo paraugu proporcija atkarībā no sezonas bija 33,3\% līdz 56,7\%, bet sezonu augstākās aktivitātes periodā varēja sasniegt pat 90\% (3.2. attēls).

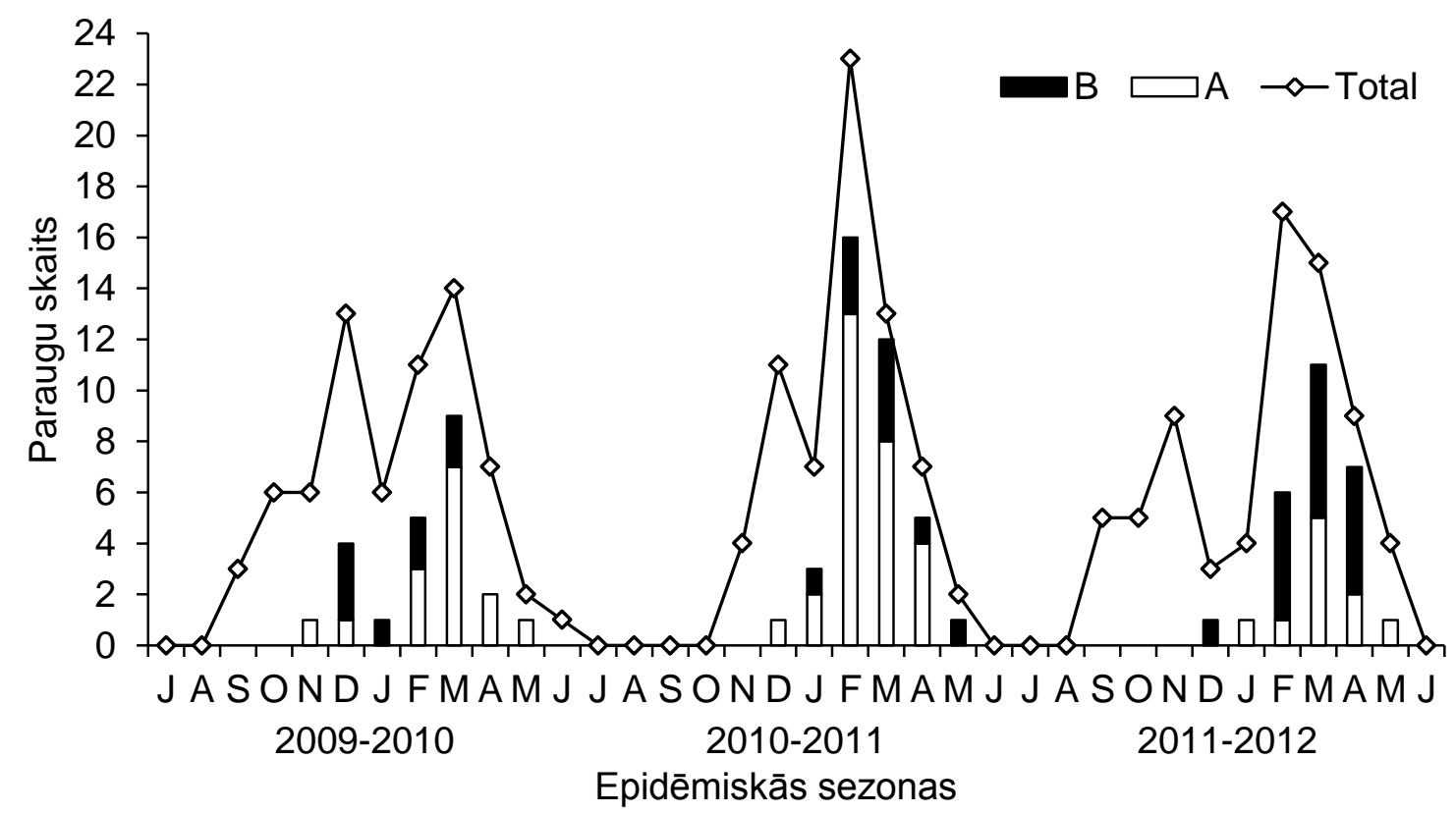

3.2. att. HRSV pozitīvo paraugu sadalījums pa pētījuma mēnešiem

Kopējais pārbaudīto paraugu skaits (līkne) un HRSV-A (baltie stabiņi) un B (melnie stabiṇi) pozitīvo paraugu skaits katrā mēnesī. Mēneši norādīti ar tā pirmo burtu, sākot no 2009. gada jūlija 
Katru gadu HRSV epidēmija sākās ziemas un ieilga līdz pavasara mēnešiem. HRSV epidēmiskās aktivitātes pīķis bija 10. gada nedēḷa, bet kopumā HRSV pozitīvi paraugi tika detektēti no 46. līdz 21. nedēḷai (3.2. tabula).

3.2. tabula

\section{HRSV sezonu raksturojums}

\begin{tabular}{lcccc}
\hline \multirow{2}{*}{ Epidēmiskā sezona } & \multicolumn{4}{c}{ Nedēḷas } \\
\cline { 2 - 5 } & $\begin{array}{c}\text { Pirmais } \\
\text { detektētais paraugs }\end{array}$ & Sezonas pīḳis* & $\begin{array}{c}\text { Pēdējais } \\
\text { detektētais paraugs }\end{array}$ & Ilgums \\
\hline $2009-2010$ & 46 & 9 & 19 & 26 \\
$2010-2011$ & 52 & 6 & 21 & 22 \\
$2011-2012$ & 51 & 10 & 18 & 20 \\
Kopā & 46 & 10 & 21 & 28 \\
\hline * Pīķis ataino HRSV pozitīvo paraugu sadalījuma pa nedẹlā̄m modu
\end{tabular}

HRSV epidemioloǵiskās aktivitātes sākums tika noteikts kā pirmā no divām secīgām nedēlāam, kurās $\geq 10 \%$ testēto paraugu ir HRSV pozitīvi, savukārt beigas kā pēdējā no divām secīgām nedēlāam, kurās $\geq 10 \%$ testēto paraugu ir HRSV pozitīvi. Analizējot kopā trīs sezonu datus, HRSV epidemiologisiskās aktivitātes periods tika noteikts no 51. līdz 19. gada nedēlai, kas labi atbilda arī sadalījuma intervālam no -2 SD līdz +2 SD - 52. līdz 19. nedēḷa. Lai izslēgtu datu vākšanas ietekmi uz sezonalitātes datiem, tika pārbaudīta korelācija starp HRSV pozitīvo un negatīvo paraugu sadalījumiem pa nedēlāam, un tāda netika atrasta $(r=0,1)$. Šajā pētījumā noteiktajā HRSV epidemioloğiskās aktivitātes periodā izraisīja 57\% (86 no 151) dziḷāko elpecel̦u infekcijas, 92,9\% (26 no 28) bronhiolītu un 51,4\% (18 no 35) pneimoniju. Savukārt, ārpus š̄ perioda HRSV izrasīja 3,6\% (2 no 56) dziḷāko elpceḷu infekciju.

HRSV-A un B vīrusi paralēli cirkulēja visās trijās pētītajās sezonas. HRSV-A dominēja sezonās 2009./2010. un 2010./2011., kamēr HRSV dominēja 2011./2012. sezonā (3.3. tabula). 
HRSV grupu izplatība epidēmiskajās sezonās

\begin{tabular}{lcccc}
\hline \multirow{2}{*}{ Epidēmiskā sezona } & \multirow{2}{*}{$\begin{array}{c}\text { Pārbaudītie } \\
\text { paraugi }\end{array}$} & \multirow{2}{*}{$\begin{array}{c}\text { HRSV-pozitīvie } \\
\text { paraugi, sk. (\%) }\end{array}$} & \multicolumn{2}{c}{$\begin{array}{c}\text { Paraugu skaits starp HRSV- } \\
\text { pozitīvajiem (\%) }\end{array}$} \\
\cline { 4 - 5 } $2009-2010$ & 69 & $23(33,3)$ & HRSV-A & HRSV-B \\
$2010-2011$ & 67 & $38(56,7)$ & $28(73,7)$ & $8(34,8)$ \\
$2011-2012$ & 71 & $27(38)$ & $10(37)$ & $17(26,3)$ \\
Kopā & 207 & $88(42,5)$ & $53(60,2)$ & $35(39,8)$ \\
\hline
\end{tabular}

\subsubsection{HRSV klīniskās pazīmes}

HRSV infekcijas klīniskās pazīmes ir norādītas 3.2. attēlā. Bez sēkšanas, klepus un mitriem trokšņiem, kas daļēji ir iekļauti šī pētîjuma dziḷāko elpcel̦u infekcijas gadījuma definīcijā, lielākajai daļai pacientu ar HRSV infekciju tika novēroti arī rinīts, miegainība, samazināta ēstgriba un subkostālas retrakcijas. Cits gadījuma definīcijas kritērijs, apnoja, netika novērots pētījuma populācijā. Lielākā daḷa pacientu vecāki atminējās kontaktu ar akūtas respiratoras infekcijas slimnieku. 


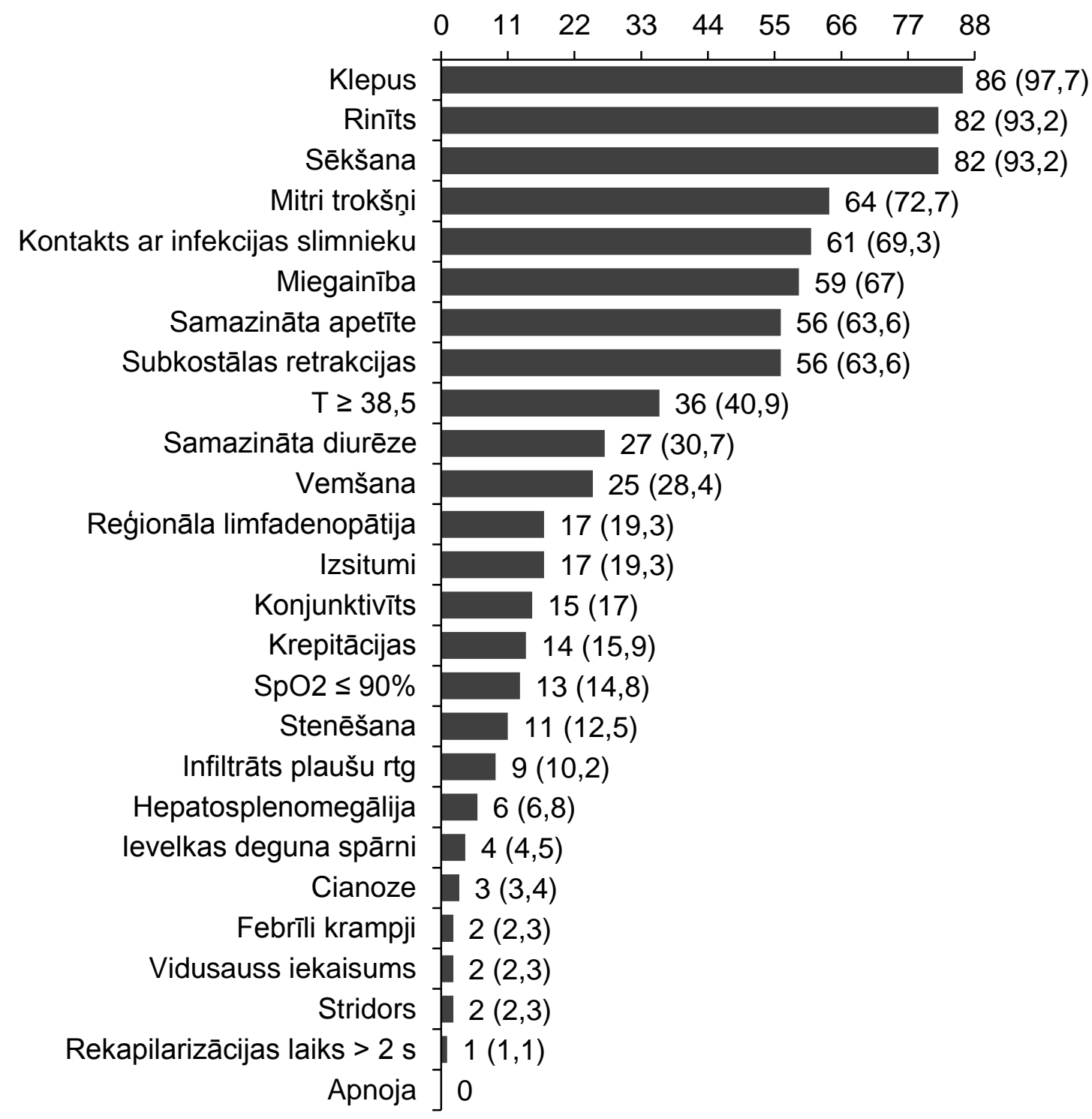

\section{2. att. HRSV izraisītu dziḷāko elpcẹ̦u infekcijas klīniskais atainojums}

Klīniskās pazīmes izteiktas kā HRSV pozitīvo pacientu skaits (\%) ar pazīmi.

$\mathrm{T}$ - temperatūra, ${ }^{\circ} \mathrm{C} ; \mathrm{SpO}_{2}$ - skābekḷa saturācija mērot ar pulsoksimetru; rtg - rentgenogramma

Veicot HRSV izraisītu dziḷāko elpceḷu infekciju klīnisko salīdzinājumu ar citu etiologijas grupu (respektīvi, "ne-HRSV" grupa), tika konstatēta virkne atšķirību (3.4. tabula): (i) ar HRSV inficētie pacienti bija statistiski ticami jaunāki, (ii) viniem biežāk ǵimenes anamnēzē bija atopiskas saslimšanas, bet (iii) retāk tika noteikts SIRS. Atškīīās arī noteiktās diagnozes - HRSV biežāk izraisīja bronhiolītu, bet netika diagnosticēts nevienam no pacientiem ar obstruktīvu laringotraheītu (krupu). Savukārt, neatšķīrās neviens no lietotajiem slimības smaguma rādītājiem - prasība pēc skābekḷa inhalācijas, RDNI, KSS 
un hospitalizācijas ilguma. Pêtījuma laikā nomira viens (0,5\%) pacients ar dziḷāko elpceļu infekciju, kas bija HRSV negatīvs.

3.4. tabula

HRSV izraisītu un citas etioloğijas dziḷāko elpceḷu infekciju klīniskais salīdzinājums

\begin{tabular}{|c|c|c|c|}
\hline Pazīme & HRSV & Ne-HRSV & $\begin{array}{c}\mathrm{P} \\
\text { vērtíba }\end{array}$ \\
\hline Pacientu skaits & 88 & 119 & \\
\hline Meitenes, sk. (\%) & $38(43,2)$ & $42(35,3)$ & 0,249 \\
\hline Vecums mēnešos, mediāna (starpkvartīlu izkliede) & $6(3-9,25)$ & $10(6-16,5)$ & $<0,001$ \\
\hline $\begin{array}{l}\text { Svars atbilstoši vecumam, } z \text {-vērtības mediāna } \\
\text { (starpkvartīḷ izkliede) }\end{array}$ & $\begin{array}{c}0,69(-0,17- \\
1,24)\end{array}$ & $\begin{array}{c}0,84(0,04- \\
1,36)\end{array}$ & 0,252 \\
\hline Pasīvā smēķēšana, sk. (\%) & $59(67)$ & $68(57,1)$ & 0,148 \\
\hline Apdzīvotības indekss, mediāna ${ }^{a}$ (starpkvartīịu izkliede) & $1,7(1,3-2)$ & $1,7(1,3-2)$ & 0,424 \\
\hline Atopiskas slimības gimenē, sk. (\%) & $50(56,8)$ & $51(42,9)$ & 0,047 \\
\hline Sistēmiskā iekaisuma atbildes sindroms (SIRS), sk. (\%) & $17(19,3)$ & $79(66,4)$ & $\mathbf{0 , 0 2 3}$ \\
\hline Prasība pēc skābekḷa, sk. (\%) & $27(30,7)$ & $46(38,7)$ & 0,235 \\
\hline $\begin{array}{l}\text { Respiratorā distresa novērtēšanas instruments, mediāna } \\
\text { (starpkvartīḷ izkliede) }\end{array}$ & $6(5-8)$ & $6(4-8)$ & 0,839 \\
\hline Klīniskā smaguma skala, moda (izkliede) & $1(1-6)$ & $1(0-5)$ & 0,21 \\
\hline Antibakteriāla terapija, sk. (\%) & $31(35,2)$ & $45(37,8)$ & 0,703 \\
\hline Stacionēšanas ilgums, mediāna (starpkvartīḷu izkliede) & $4(3-6)$ & $4(2-6)$ & 0,651 \\
\hline Diagnoze & & & $<0,001$ \\
\hline Bronhīts & $40(45,5)$ & $55(46,2)$ & 0,913 \\
\hline Bronhiolīts & $27(30,7)$ & $13(10,9)$ & $\mathbf{0 , 0 0 1}$ \\
\hline Pneimonija & $19(21,6)$ & $33(27,7)$ & 0,398 \\
\hline Astma & $2(2,3)$ & $7(5,9)$ & 0,306 \\
\hline Krups & 0 & $11(9,2)$ & $\mathbf{0 , 0 0 2}$ \\
\hline
\end{tabular}

${ }^{a}$ aprēḳināts dalot cilvēku skaitu ǵimenē ar istabu skaitu. P vērtības $<0,05$ norādītas trekninājumā.

58\% (n=51) bērnu ar HRSV infekciju bija vecumā līdz sešiem mēnešiem, salīdzinot ar 29,4\% (n=35) citas etioloǵijas grupā $(\mathrm{p}<0,001)$, bet 79,5\% (n=80) vecumā līdz gada vecumam, salīizinot ar 64,7\% $(n=64)$ citas etiologijas grupā $(p=0,03)$ (3.3. attēls). 


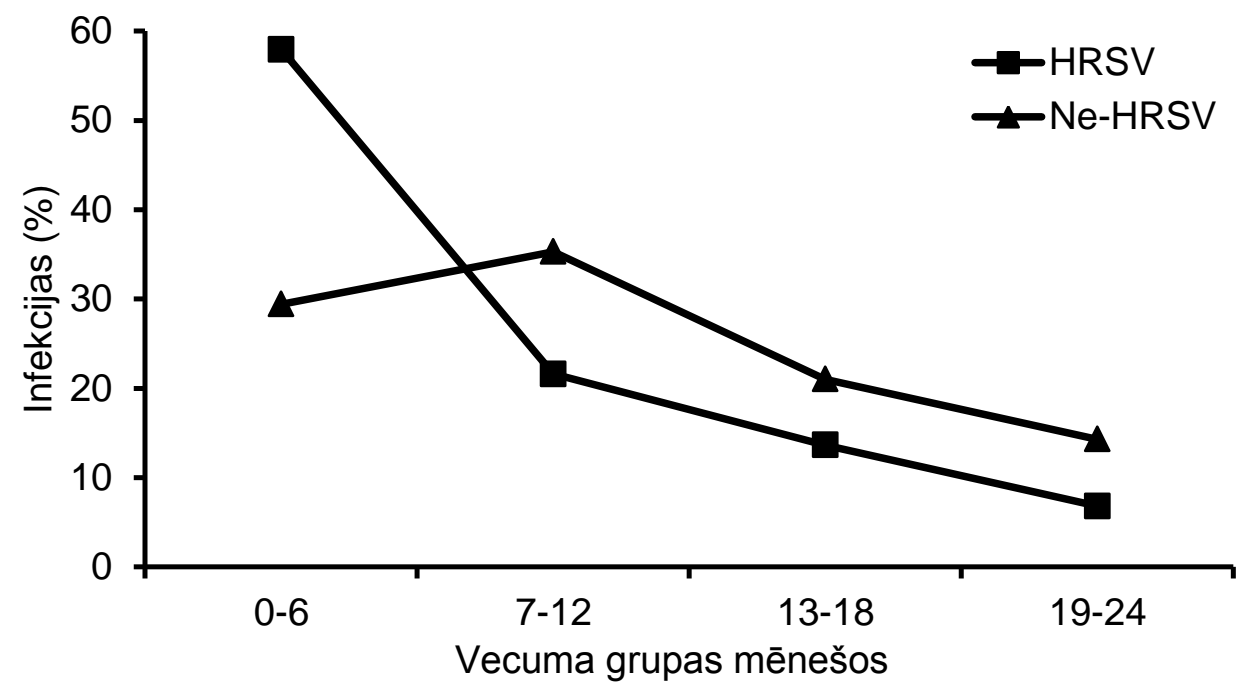

\section{3. att. Vecuma struktūras pacientiem ar HRSV izraisītu un citas etiologiijas dziḷāko elpceḷu infekcijām}

3.4. attēlā atainota resursu izmantošana HRSV izraisītās dziḷāko elpceļu infekcijas ārstēšanā. Lielākajai daļai pacientu tika nozīmēti: krūškurvja rentgens, $\beta_{2}$ agonistu inhalācijas, intravenozs infūzs un intravenozus $(n=56 ; 63,4 \%)$ vai inhalējamus $(n=68$; 77,3\%) glikokortikoīdus (54 pacienti jeb 61,4\% saṇēma gan intravenozi, gan inhalācijās).

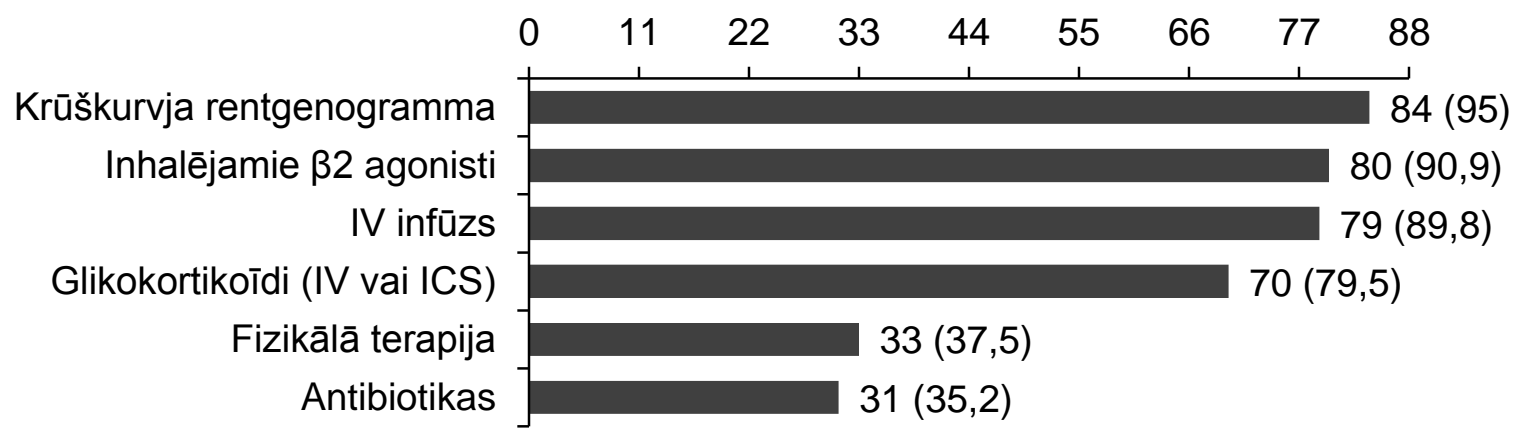

3.4. att. Resursu izmantošana HRSV izraisītās dzị̣āko elpceḷu infekcijas ārstēšanā Izteikts kā HRSV pozitīvo pacientu skaits (\%), kas sañēma norādītās intervences. IV - intravenozi; ICS inhalējamie glikokortikoīdi

Salīdzinot HRSV-A un B klīniskās pazīmes un pacientu demogrāfiskos datus, statistiski ticamas atş̌kirības netika konstatētas nevienā no salīdzinātajiem parametriem (3.5. tabula). 
3.5. tabula

HRSV grupu A un B klīniskais salīdzinājums

\begin{tabular}{|c|c|c|c|}
\hline Pazīme & HRSV-A & HRSV-B & $\begin{array}{c}\mathrm{P} \\
\text { vērtība }\end{array}$ \\
\hline Pacientu skaits & 53 & 35 & \\
\hline Meitenes, sk. (\%) & $19(35,8)$ & $19(54,3)$ & 0,087 \\
\hline Vecums mēnešos, mediāna (starpkvartīḷ izkliede) & $6(3-9)$ & $6(3,75-12)$ & 0,518 \\
\hline $\begin{array}{l}\text { Svars atbilstoši vecumam, } z \text {-vērtības mediāna } \\
\text { (starpkvartīḷ izkliede) }\end{array}$ & $\begin{array}{l}0,53(-0,2- \\
1,1)\end{array}$ & $\begin{array}{c}0,91(-0,01- \\
1,29)\end{array}$ & 0,279 \\
\hline Pasīvā smēķēšana, sk. (\%) & $37(69,8)$ & $22(62,9)$ & 0,497 \\
\hline Apdzīvotības indekss, mediāna (starpkvartīlı izkliede) & $\begin{array}{l}1,7(1,3- \\
2,5)\end{array}$ & $1,6(1,4-2)$ & 0,552 \\
\hline Atopiskas slimības gimenē, sk. (\%) & $23(43,4)$ & $13(37,1)$ & 0,633 \\
\hline Sistēmiskā iekaisuma atbildes sindroms (SIRS), sk. (\%) & $12(22,6)$ & $5(14,3)$ & 0,331 \\
\hline Prasība pēc skābekḷa, sk. (\%) & $17(32,1)$ & $10(28,6)$ & 0,727 \\
\hline $\begin{array}{l}\text { Respiratorā distresa novērtēšanas instruments, mediāna } \\
\text { (starpkvartīḷ izkliede) }\end{array}$ & $6(4-8)$ & $7(5,5-8)$ & 0,928 \\
\hline Klīniskā smaguma skala, moda (izkliede) & $1(1-5)$ & $1(1-6)$ & 0,303 \\
\hline Antibakteriāla terapija, sk. (\%) & $20(37,7)$ & $11(31,4)$ & 0,544 \\
\hline Stacionēšanas ilgums, mediāna (starpkvartīḷu izkliede) & $4(3-6)$ & $3(2-4,75)$ & 0,163 \\
\hline Diagnoze & & & 0,316 \\
\hline Bronhīts & $26(49,1)$ & $14(40)$ & 0,538 \\
\hline Bronhiolīts & $18(34)$ & $9(25,7)$ & 0,559 \\
\hline Pneimonija & $8(15,1)$ & $11(31,4)$ & 0,119 \\
\hline Astma & $1(1,9)$ & $1(2.9)$ & 1 \\
\hline
\end{tabular}

\subsection{HRSV molekulārais raksturojums}

\subsubsection{Filoğenētiskā analīze}

Salīdzinot nt sekvences, 53 HRSV-A un 35 HRSV-B izolāti tika sagrupēti attiecīgi 29 un 23 dažādos celmos. Šo celmu sekvences tika izkārtotas kopā ar GenBank pieejamajām celmu sekvencēm ar iepriekš noteiktiem genotipiem. Kopumā analīzē tika iekḷauti 11 HRSV-A genotipi (GA1-7 [Peret et al., 2000], SAA1 [Venter et al., 2001], NA1 un 2 [Shobugawa et al., 2009], ON1 [Eshaghi et al., 2012]) un 13 HRSV-B genotipi (GB14 [Peret et al., 2000], SAB1-3 [Venter et al., 2001], BA-I-VI [Trento et al., 2006]). Uz šo izkārtojumu bāzes katrai grupai atsevišķi tika veikta filoğenētiskā analīze ar NJ metodi. Abu grupu gadījumā par piemērotāko nt substitūcijas modeli tika atzịta Tamura-Nei 
(TN93) metode [Tamura and Nei, 1993] ar diskrētu gamma distribūciju (formas parametrs $=4)$.

Latvijas HRSV-A izolāti piederēja diviem dažādiem genotipiem. 28 celmi (51 izolāts) piederēja genotipam NA1. Viens celms, kurā ietilpa divas identiskas sekvences, abas izolētas 2012. gada martā, piederēja nesen aprakstîtajam genotipam ON1 (3.5. un 3.7. attēli). Šo genotipu raksturo 72 nt duplikācija HVR2 segmentā (3.8. un 3.9. attēli) [Eshaghi et al., 2012]. 


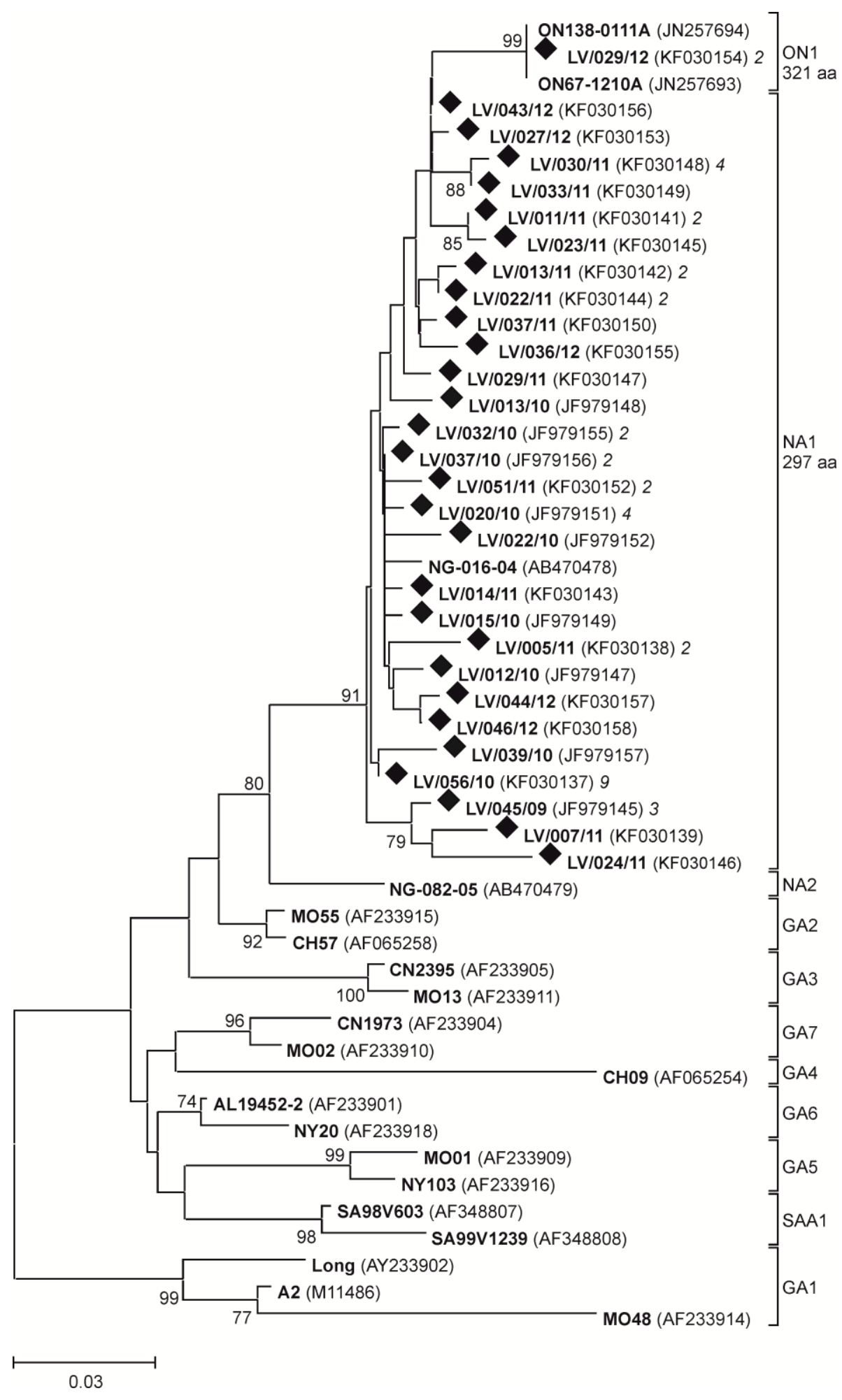

\section{5. att. HRSV A grupas filogenētiskais koks}

Latvijas celmi ir apzīmēti ar $(\diamond)$. Taksonu apzīmējumi ietver: celma nosaukumu (trekninājumā), iekavās norādītu GenBank pieejas kodu un kursīvā norādītu identisko izolātu skaitu. Sākumpalaišanas vērības, kas $\geq 70$, norādītas mezglos. Skala norāda nukleotīdu substitūciju skaitu pozīcijā. 


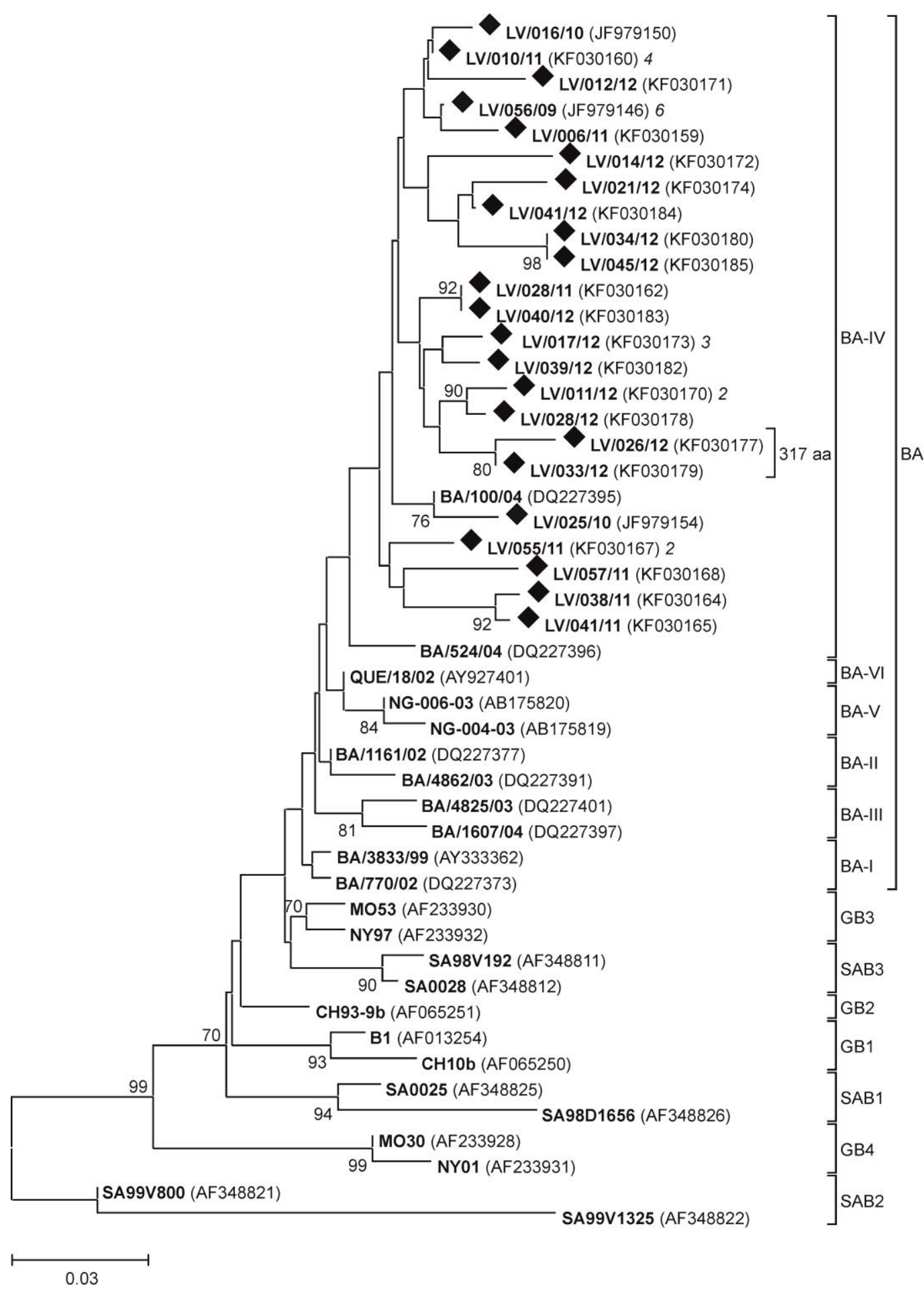

3.6. att. HRSV B grupas filog̀enētiskais koks

Apzīmējumi lietoti kā 3.5. attēla aprakstā. Celmi ar 317 aminoskābju garu $G$ proteīnu ir norādīti atsevišķi, pārējiem celmiem bija 310 aminoskābju garš $\mathrm{G}$ proteīns. 
Visiem HRSV-B izolātiem tika konstatēta 60 nt duplikācija G gēnā, kas raksturīga BA genotipiem, un tie visi piederēja BA-IV genotipam (3.6. attēls). Kopējais HRSV izolātu sadalījums pa genotipiem analizētajās sezonās dots 3.7. attēlā.

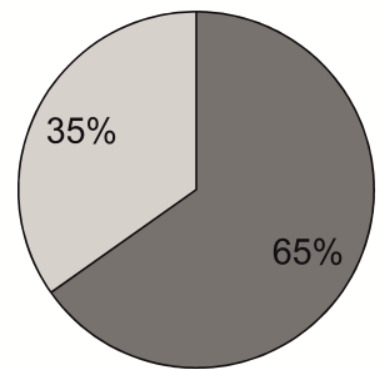

2009./2010.

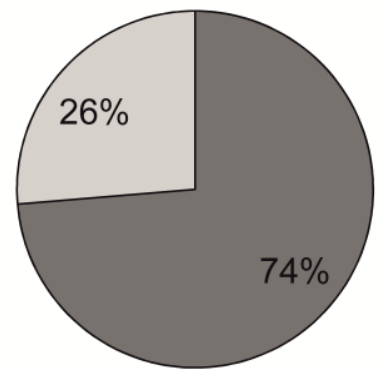

2010./2011.

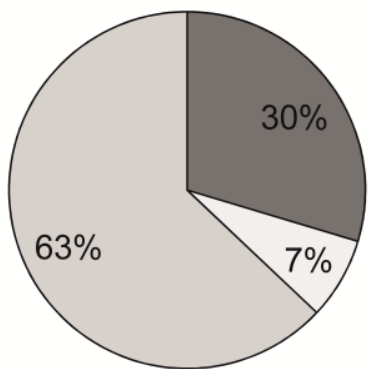

2011./2012.

NA1 $\square$ BA-IV $\square$ ON1

\section{7. att. HRSV izolātu sadalījums pa genotipiem analizētajās sezonās}

Astoņi HRSV-A un viens HRSV-B celms bija identiski iepriekš citur izolētām sekvencēm, izmantojot NCBI-BLAST servera meklētāju (3.6. tabula) [Zhang et al., 2000]. Pārējie 43 (no 52) celmi bija Latvijai unikāli. 
3.6. tabula

Iepriekš publicēti identiski celmi Latvijas 2009.-2012. gadu izolātiem

\begin{tabular}{|c|c|c|c|c|c|}
\hline \multicolumn{2}{|c|}{ Latvijā } & \multicolumn{4}{|c|}{ Pasaulē } \\
\hline Celms & Sezona & Celms* & Sezona & Valsts & $\begin{array}{c}\text { GenBank } \\
\text { pieejas } \\
\text { kods }\end{array}$ \\
\hline \multicolumn{6}{|c|}{ Genotips NA1 } \\
\hline \multirow[t]{2}{*}{$\mathrm{LV} / 056 / 10$} & 2010-2011 & NL20752227/07-08 & $2007-2008$ & Nīderlande & HQ731761 \\
\hline & 2011-2012 & Riyadh 42/2008 & 2008-2009 & Saūda Arābija & JX131640 \\
\hline LV/009/11 & 2010-2011 & $08-047045$ & 2008-2009 & Nīderlande & JX015483 \\
\hline \multirow[t]{6}{*}{ LV/011/11 } & $2010-2011$ & $\mathrm{~A} / \mathrm{RJ} / 64 / 2006$ & 2006-2007 & Brazīlija & JX182800 \\
\hline & & $\mathrm{A} / \mathrm{RJ} / 288 / 2007$ & $2007-2008$ & Brazīlija & JX182830 \\
\hline & & A/RS/5357/2009 & 2009-2010 & Brazīlija & JX182837 \\
\hline & & A/WI/629-22/07 & 2007-2008 & $\mathrm{ASV}$ & JF920049 \\
\hline & & R9061/07-08 & $2007-2008$ & Lielbritānija & HQ731741 \\
\hline & & R14944/08-09 & 2008-2009 & Lielbritānija & HQ731736 \\
\hline $\mathrm{LV} / 027 / 12$ & 2011-2012 & 18227AN/2012 & 2011-2012 & Itālija & JX988459 \\
\hline \multirow[t]{2}{*}{$\mathrm{LV} / 036 / 12$} & 2011-2012 & 18294RM/2012 & 2011-2012 & Itālija & JX988494 \\
\hline & & HD/70178486/11 & 2011-2012 & Vācija & JX967562 \\
\hline \multirow[t]{5}{*}{$\mathrm{LV} / 043 / 12$} & $2011-2012$ & ON69-0310A & 2009-2010 & Kanāda & JN257697 \\
\hline & & ON187-0111A & $2010-2011$ & Kanāda & JN257701 \\
\hline & & $\begin{array}{l}\text { A/WI/629- } \\
\text { Q0284/10 }\end{array}$ & $2009-2010$ & ASV & JF920053 \\
\hline & & 07408AN/2012 & 2011-2012 & Itālija & JX988460 \\
\hline & & HD/70189233/12 & 2011-2012 & Vācija & JX967566 \\
\hline $\mathrm{LV} / 046 / 12$ & 2011-2012 & 16158AN/2012 & 2011-2012 & Itālija & JX988467 \\
\hline \multicolumn{6}{|c|}{ Genotips ON1 } \\
\hline \multirow[t]{5}{*}{$\mathrm{LV} / 029 / 12$} & 2011-2012 & ON138-0111A & $2010-2011$ & Kanāda & JN257694 \\
\hline & & 0284RM/2012 & 2011-2012 & Itālija & JX988452 \\
\hline & & WUE/9583/12 & 2011-2012 & Vācija & JX912363 \\
\hline & & RSVA/GN435/11 & 2011-2012 & Dienvidkoreja & JX627336 \\
\hline & & $\begin{array}{c}\text { RSV/Yokohama.JPN/ } \\
\text { /P6587/2012 }\end{array}$ & 2011-2012 & Japāna & AB761611 \\
\hline
\end{tabular}

Genotips BA-IV

LV/010/11 2010-2011 BE/8844/09 2009-2010 Beligija $\quad$ JX645922

* Celmi ar $100 \%$ maksimālo identitāti NCBI-BLAST servera meklēšanā. Norādīts tikai viens celms no katras valsts attiecīgajā sezonā.

\subsubsection{Genotipa NA1 molekulārais raksturojums}

Genotipa NA1 Latvijas celmu HVR2 sekvences bija savstarpēji cieši saistītas, un genētiskie attālumi bija $2,1 \%( \pm 0,4)$ un $4,1 \%( \pm 0,9)$ attiecīgi nt un aa līmenī. Nukleotīdu 
polimorfisms kodonu pozīcijās un deducēto aa izkārtojums ir dots 3.8. attēlā. Kopumā 112 aa garajā analizētajā sekvencē 63 references celma A2 aa bija konservatīvas visos izolātos. Visiem HRSV-A celmiem bija priekšlaicīgs terminācijas kodons (TGA) 298. pozīcijā un saglabāts oriǵinālais (celma A2) terminācijas kodons 299. pozīcijā (3.9. attēls). Visiem NA1 celmiem tika atklātas arī sekojošas mutācijas: $P 226 \rightarrow L, E 233 \rightarrow K, L 258 \rightarrow H / Y$, $M 262 \rightarrow E / R, \quad F 265 \rightarrow L, S 269 \rightarrow T, \quad S 280 \rightarrow Y, P 289 \rightarrow S, S 290 \rightarrow P / L, P 292 \rightarrow S, P 293 \rightarrow S$, $P 296 \rightarrow T$ un $R 297 \rightarrow K$. Citas biežas $(>50 \%$ celmu) mutācijas bija: $L 208 \rightarrow I, S 222 \rightarrow P$, $N 237 \rightarrow D, I 244 \rightarrow R, N 273 \rightarrow Y / K, P 274 \rightarrow L$ un $P 286 \rightarrow L$. Vidējā ǵenētiskā distance starp Latvijas celmiem un NA1 references celmu NG-016-04 (GenBank pieejas kods AB470478) bija 2,3\% $( \pm 0,4)$ un $4,2 \%( \pm 0,9)$ attiecīgi nt un aa līmenī.

Izmantojot NetOGlyc 3.1 serveri, potenciāla $O$-glikozilācija tika prognozēta 40 serīna un treonīna atlikumiem (starp individuāliem celmiem no 36 līdz 43). Analogā celma A2 sekvencē tika prognozētas $39 O$-glikozilācijas vietas, no kurām 36 bija kopīgas ar Latvijas konsensa sekvenci. Celma A2 HVR2 segmentā ir divi potenciāli $N$-glikozilācijas motīvi (N-X-S/T) - N237 un N251. Starp Latvijas celmiem bija sastopami vēl divi motīvi N273 un N294. NetNGlyc 1.0 serveris prognozēja tikai N251 un N294 N-glikozilāciju Latvijas konsensa sekvencē. Starp individuāliem celmiem prognozētās $N$-glikozilācijas pozīcijas variēja no 0 līdz 3. Tripeptīdam NLS 273. pozīcijā seko prolīns, kas šī asparagīna glikozilāciju padara maz varbūtīgu [Gupta et al., 2004], savukārt 294. pozīcijā esošā NTT glikozilācija bija šksietami atkarīga no $P 286 \rightarrow L$ mutācijas. Neviens no $N$-glikozilācijas motīviem nebija kopīgs visiem izolātiem.

Lai identificētu pozitīvās selekcijas vietas, tika izmantotas piecas dažādas metodes. Kopumā 28 pozīcijās bija paaugstināta ne-sinonīmo nomaiṇu $(d N)$ proporcija un vidējā nesinonīmo/sinonīmo nomaiņu $(d N / d S)$ attiecība bija 1,12, kas liecina par selekcijas spiediena klātbūtni. Neskatoties uz to, tikai divas pozīcijas, M262 un N273, tika noteiktas balstoties uz divu vai vairāk metožu konsensu (3.8. attēls, 3.7. tabula). N273 nomaiṇa uz tirozīnu izjauca N-X-S/T N-glikozilācijas motīvu. 


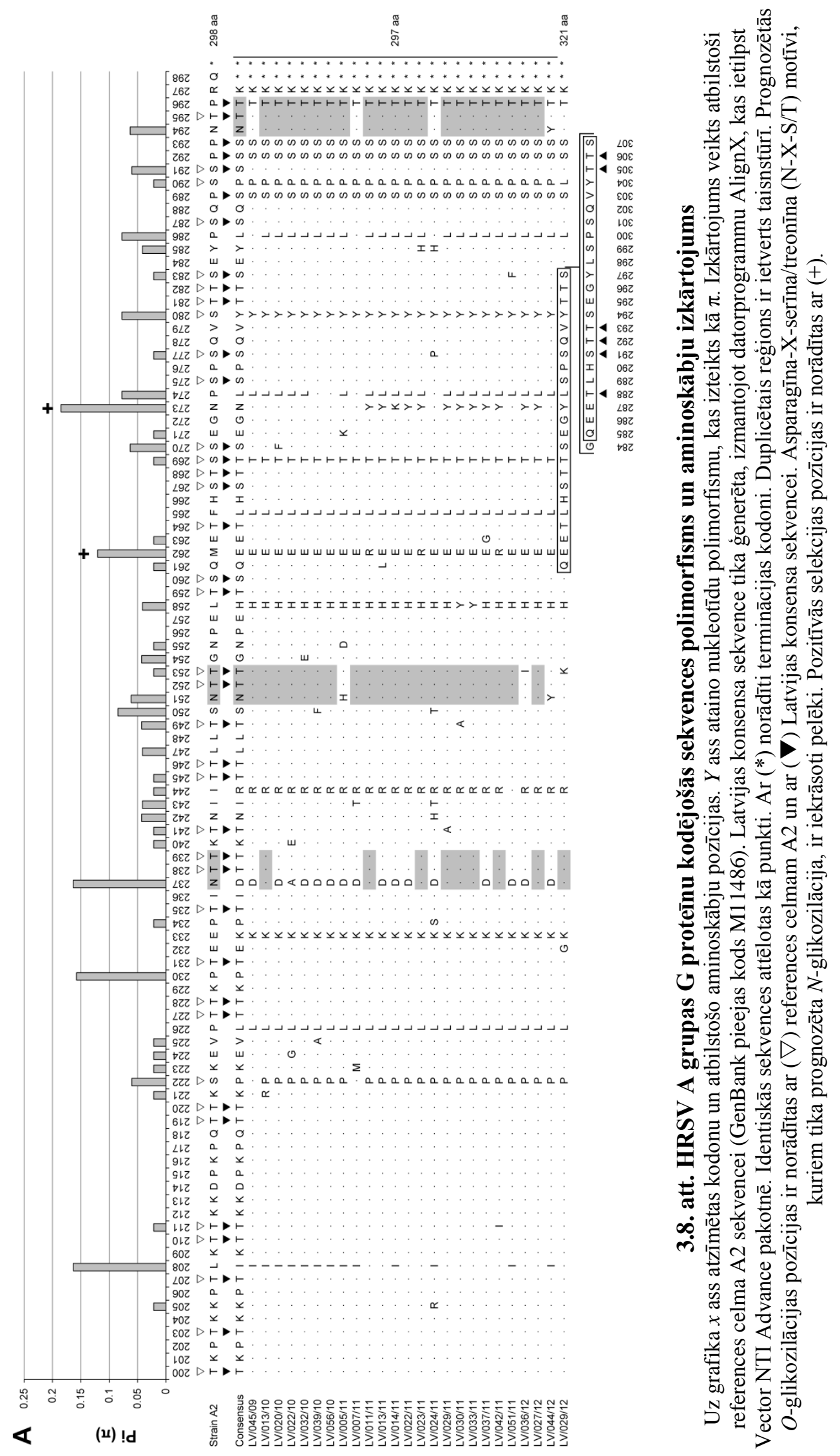


HRSV-A

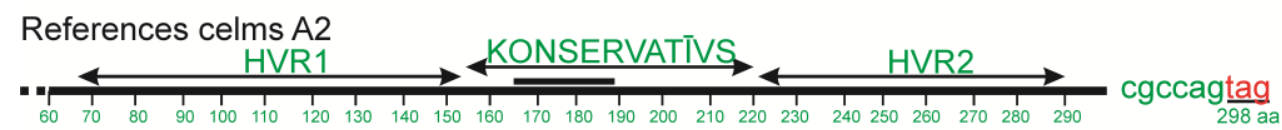

(I)
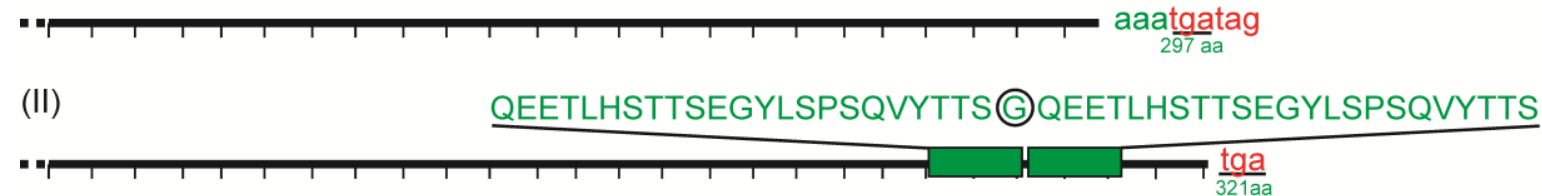

HRSV-B

References celms B1

caaaatacccaatcacatgcttag

(III)

TERDTSTSQSTVLDTTTSKH TERDTSTSQSIVLDTTTSKH

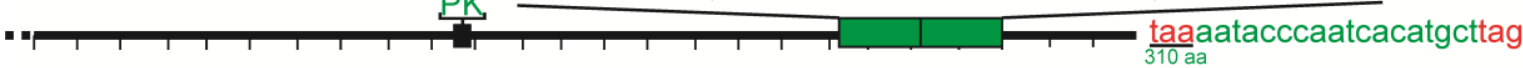

(IV)

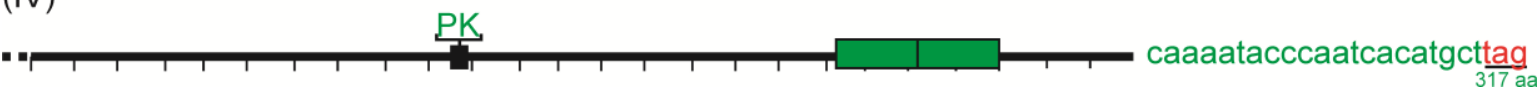

3.9. att. Latvijas izolātu $G$ proteīna ektodomēna variabilitāte

Lineārais attēlojums ir balstīts uz prototipu celmu A2 un B1 sekvencēm. I, priekšlaicīgs terminācijas kodons (pasvītrotie nukleotīdi), kas terminē 297 aminoskābju garu proteīnu, ir raksturīgs visiem Latvijas HRSV-A izolātiem. II, diviem HRSV-A izolātiem tika konstatēta 72 nukleotīdu duplikācija (zalšs taisnstūris) otrajā hipervariablajā rajonā. III, sešu nukleotīdu delēcija (ロ), 60 nukleotīdu duplikācija un priekšlaicīgs terminācijas kodons, veidojot 310 aminoskābju garu proteīnu, ir raksturīgi lielākajai daļai Latvijas HRSV-B izolātu. IV, diviem HRSV-B izolātiem bija saglabāts orig̣inālais celma B1 terminācijas kodons, šie proteīni bija 317 aminoskābju gari. Diagrammu atainojums un izmantotie simboli lietoti kā [Zlateva et al., 2005].

3.7. tabula

Kodoni zem pozitīvās selekcijas spiediena

\begin{tabular}{lccccc}
\hline Kodons & SLAC & FEL & IFEL & REL & MEME \\
\hline HRSV-A & & & & & \\
M262 & 0.45 & 0.16 & $\mathbf{0 . 0 3}$ & 2.89 & $\mathbf{0 . 0 1}$ \\
N273 & 0.59 & $\mathbf{0 . 0 8}$ & $\mathbf{0 . 0 9}$ & 3.42 & $\mathbf{0 . 0 8}$ \\
P274 & 0.26 & 0.21 & $\mathbf{0 . 0 7}$ & 2.95 & 0.23 \\
HRSV-B & & & & & \\
L219 & $\mathbf{0 . 0 6}$ & $\mathbf{0 . 0 9}$ & $\mathbf{0 . 0 4}$ & 14.36 & 0.11 \\
T270 & 0.30 & $\mathbf{0 . 0 5}$ & 0.14 & $\mathbf{6 5 . 1 3}$ & $\mathbf{0 . 0 7}$ \\
\hline
\end{tabular}

SLAC, FEL, IFEL un MEME statistiskā nozīmība ir izteikta ar $\mathrm{p}$ vērtību, bet REL ar Baijesa faktoru (BF). Vērtības trekninājumā tika uzskatītas par statiski nozīmīgām ( $\mathrm{p}<0,1$; BF >20). Pasvìtrotie kodoni atbilda divu vai vairāk metožu kritērijiem. 


\subsubsection{Genotipa BA-IV molekulārais raksturojums}

Latvijas BA-IV genotipa celmi bija vairāk atšksirīgi ar aprēķinātajām ǵenētiskajām distancēm 3,3\% $( \pm 0,4)$ un 4,2 \% $( \pm 0,7)$ attiecīgi nt un aa līmenī. Par to liecināja arī nt polimorfisma analīze (3.10. attēls), kur 23 kodonu $\pi$ vērtības bija $>0,1$. Papildus raksturīgajai 20 aa „rāmja” duplikācijai HVR2 segmentā visiem Latvijas BA-IV celmiem tika konstatēta arī delēcija P159-K160 (3.9. attēls). Šì divu aa delēcija mainīja kodonu pozīciju numerāciju, kas šeit norādīta, balstoties un referenču celmiem. P159-K160 delēcijai sekoja 28 aa reǵions (161.-188.), kas bija pilnībā konservatīvs Latvijas B celmos. Tika novērotas divas alternatīvas terminācijas kodonu lokalizācijas - 293. pozīcijā (TAA) vai references celma B1 (299 aa garš G proteīns) 300. pozīcijā (TAG). Tādējādi Latvijas HRSV-B vīrusi producēja 310 vai 317 aa garus G proteīnus (3.9. attēls). Celmi ar 317 aa garu G proteīnu parādījās tikai 2011./2012. sezonā un netika detektēti iepriekš. Proteīnu sekvenču izkārtojums kopā ar sākotnēji aprakstīto BA celmu BA/3833/99 ir dots 3.10. attēlā. Kopumā 171 aa garajā analizētajā sekvencē 123 references celma aa bija konservētas arī starp visiem Latvijas izolātiem. Visiem HRSV-B celmiem bija sekojošas mutācijas: $K 218 \rightarrow T, L 223 \rightarrow P$ un $S 247 \rightarrow P$. Papildus tām, biežas ( $>50 \%$ celmu) bija arī: $L 219 \rightarrow P$, $T 270 \rightarrow I / F, V 271 \rightarrow A, H 287 \rightarrow Y$ un $Q 313 \rightarrow$ Stop. Vidējā ǵenētiskā distance starp Latvijas BA celmiem un references celmu BA/3833/99 bija 4,2\% $( \pm 0,6)$ un 5,2\% $( \pm 0,9)$ attiecīgi nt un aa līmen̄i. Vairākas būtiskas atšķirības tika novērotas duplicētajā segmentā, kas vairs nebija tieša sākotnējās sekvences kopija (3.10. attēls). 


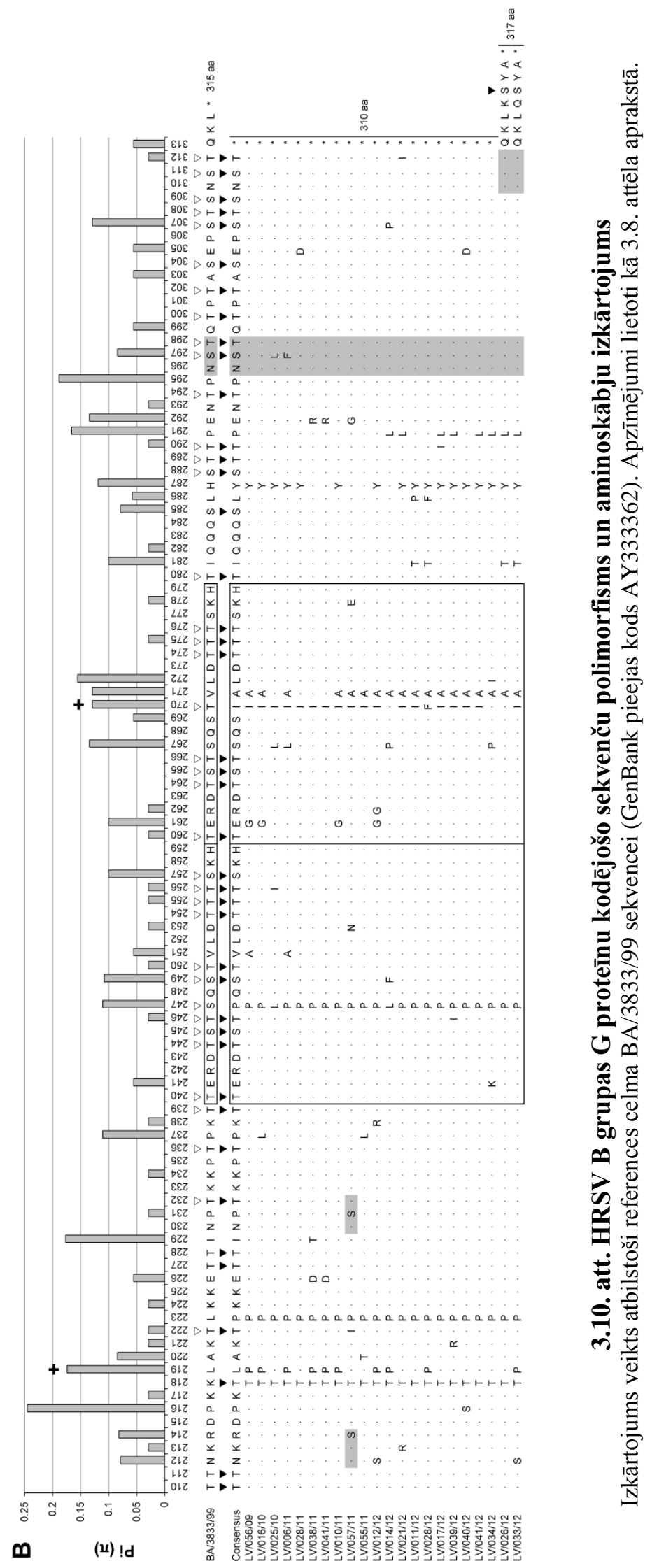


NetOGlyc 3.1 serveris prognozēja 44 serīna un treonīna atlikumu $O$-glikozilāciju Latvijas konsensa sekvencē (36-50 starp individuāliem celmiem) un 41 analogā celma BA/3833/99 sekvencē. Tikai 16 no paredzētajām $O$-glikozilācijas pozīcijām sakrita ar HRSV-A konsensa sekvenci. Celma BA/3833/99 HVR2 segmentā ir divi potenciāli $N$ glikozilācijas motīvi - N296 un N310. N296 bija konservatīvs un tā glikozilācija tika prognozēta visiem Latvijas celmiem, bet N310 glikozilācija tika prognozēta tikai 317 aa garajās sekvencēs. Celmam LV/057/10 bija uzreiz trīs papildus N-X-S/T motīvi (N212, N230 un N253), no kuriem diviem (N212 un N230) tika prognozēta $N$-glikozilācija.

Kopumā 32 pozīcijās bija paaugstināta ne-sinonīmo nomaiṇu $(d N)$ proporcija, un vidējā ne-sinonīmo/sinonīmo nomaiṇu $(d N / d S)$ attiecība bija 0,45 . Balstoties uz divu metožu sakritību, diviem kodoniem, L219 un T270, tika konstatēts pozitīvās selekcijas spiediens. T270 atrodas duplicētajā segmentā (3.10. attēls un 3.7. tabula).

\subsubsection{Genotipa ON1 globālā filodinamika un filoǵeogrāfija}

Divi vienādi HRSV-A izolāti (LV/029/12) piederēja nesen aprakstītajam genotipam ON1, un to sekvences bija identiskas sākotnēji aprakstītā izolāta sekvencei no Kanādas. Genotipu ON1 raksturo 72 nt duplikācija HVR2 segmentā, kas izraisa indel mutāciju $E 284 \rightarrow$ G un duplikāciju Q261-S283, pagarinot G proteīnu par 24 aa [Eshaghi et al., 2012]. Tā kā šim genotipam, tāpat kā NA1, ir priekšlaicīgs terminācijas kodons, rezultējošais G proteīna garums ir 321 aa (3.8. un 3.9. attēli). Duplicētais reǵions saturēja septiṇus papildus $O$-glikozilācijas recipientus, bet tas kavēja N318(294) N-glikozilāciju (3.9. attēls).

ON1 izolāti tika iegūti no diviem savstarpēji nesaistītiem pacientiem, kas bija hospitalizēti BKUS 2012. gada martā. Šie pacienti tika stacionēti dažādos laikos un atradās dažādās slimnīcas nodal̦ās, t.i. nebija saistāmi ar nozokomiālu pārnesi. Kopš atklāšanas Kanādā 2011. gadā, šis jaunais genotips ir izolēts vismaz deviṇās dažādās valstīs Ziemel̦amerikā, Eiropāa Āfrikā, Āzijā un Okeānijā. Kopumā līdz 2013. gada jūnijam GenBank bija pieejamas 42 sekvences, 16 no tām bija identiskas celmam ON67-1210A, un ǵenētiskās distances starp tām bija ļoti mazas - 0,8\% $( \pm 0,2)$ un 1,5\% $( \pm 0,5)$ attiecīgi nt un 
aa līmenī [Cui et al., 2013; Eshaghi et al., 2012; Khor et al., 2013; Lee et al., 2012; Prifert et al., 2013; Valley-Omar et al., 2013].

No GenBank iegūtās un Latvijas ON1 sekvences tika izkārtotas un izmantotas, lai veiktu ǵenētisko distanču lineārās regresijas analīzi kā laika funkciju. Lai aprēksinātu ǵenētiskās distances, tika konstruēts ML filoǵenētiskais koks, un par piemērotāko nt substitūcijas modeli šai datu kopai tika atzīta Hasegavas, Kišino un Jano (HKY85) metode [Hasegawa et al., 1985] ar diskrētu gamma distribūciju (formas parametrs =4). Korelācija starp ǵenētiskajām distancēm un izolēšanas laiku bija vāja $\left(R^{2}=0,21\right)$, bet statistiski nozīmīga $(\mathrm{p}=0,002)$, tādēḷ tika pieņemts, ka ON1 evolūcija laikā atbilst molekulārajam pulkstenim (3.11. attēls).

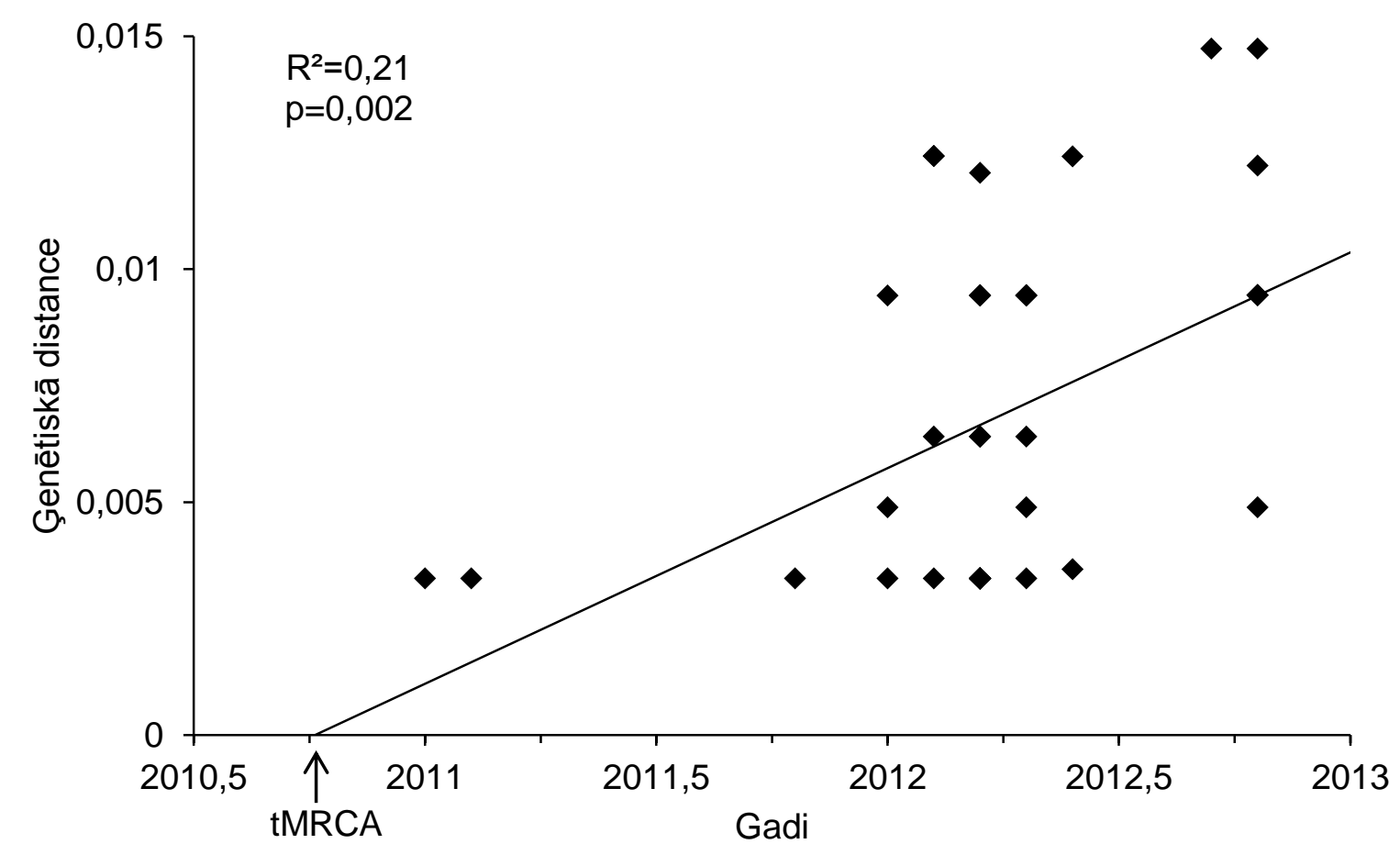

3.11. att. Genotipa ON1 izolātu genenētiskā novirze laikā

Uz y ass atainota ǵenētiskā distance no filoǵenētiskā koka saknes. tMRCA - pēc šīs analīzes aprēķinātais kopīgā ciltstēva laiks bija 2010. gada oktobris

Lai aprēķinātu maksimālās radniecības ticamības (MCC) filoǵenētisko koku (3.12. attēls), tika ǵenerēti 50 miljonu MCMC paraugi, līdz tika iegūta statistiska konverǵence. HVR2 segmenta evolūcijas ātrums tika aprēķināts $7,92 \times 10^{-3}$ nt substitūcijas/pozīcijā/gadā 
(95\% HPD: $2.97 \times 10^{-3}-1.28 \times 10^{-2}$ ), un kopīgā ciltstēva laiks (tMRCA) tika aprēķināts 2010. gada augusts (95\% HPD: 2009. gada septembris - 2011. gada janvāris).

Filoǵeogrāfiskā analīze ar labu statistisko atbalstu liecina, ka vīruss sākotnēji izplatījies no Kanādas uz Itāliju un Vāciju un tālāk uz pārējo pasauli (aposteriorā varbūtība >0,7). Ticama ir arī vīrusa diseminācija no Vācijas uz Japānu un atgriešanās Vācijā no Dienvidkorejas un Japānas. Tomēr š̄i vīrusa migrāciju uz Latviju caur Malaiziju ir ar mazu statistisko atbalstu (aposteriorā varbūtība 0,03; 3.12.). Baijesa apvāršņa grafiks tika izmantots, lai rekonstruētu genotipa ON1 populācijas dinamiku. ON1 efektīvās populācijas izmērs lēni pieauga, sasniedza plato 2012. gada sākumā un nedaudz samazinājās pirms 2012./2013. sezonas (3.12. attēls). 


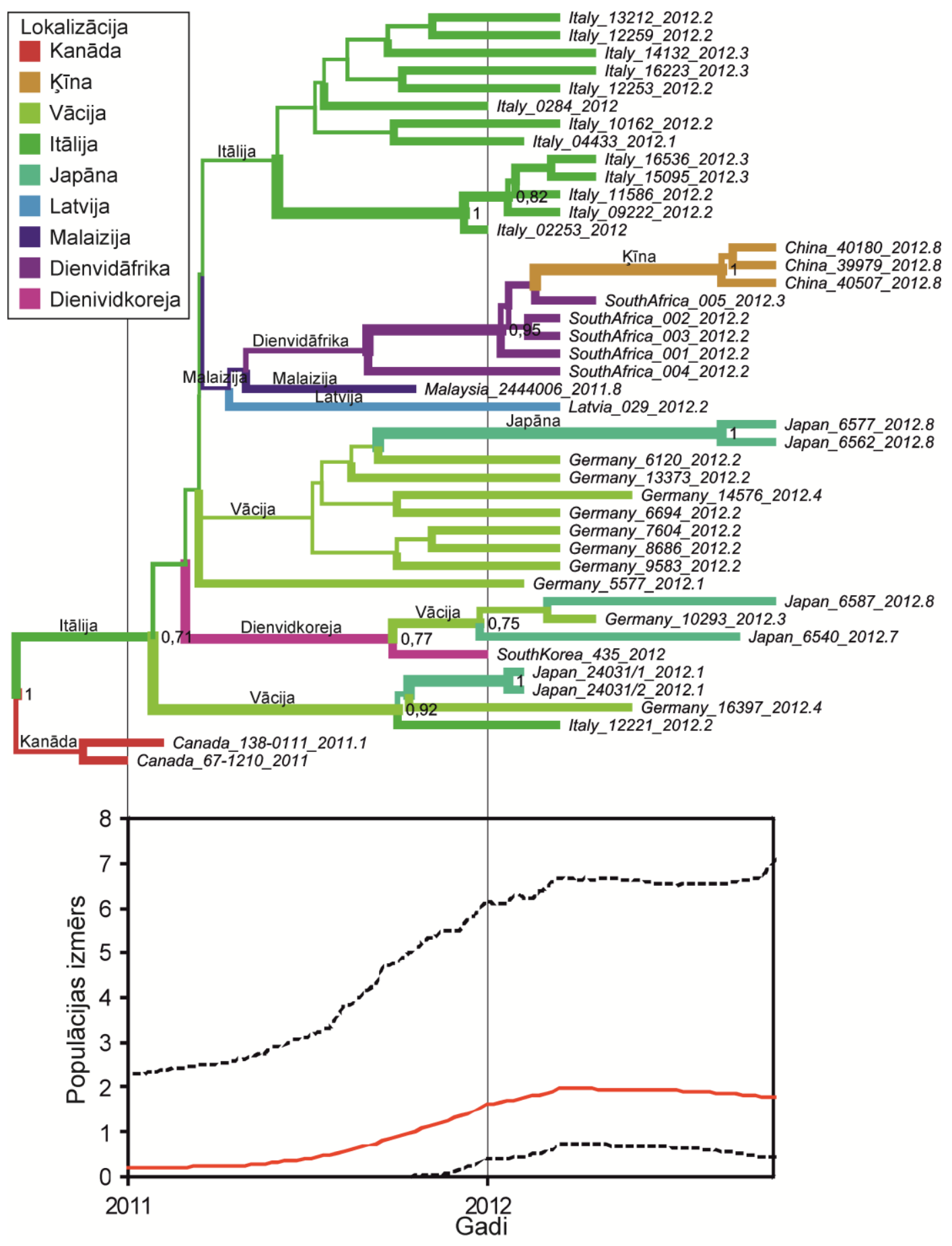

3.12. att. Genotipa ON1 diskrētā filoǵeogrāfiskā analīze un demogrāfiskā vēsture

Maksimālās radniecības ticamības (MCC) filoğenētiskais koks (augšējais panelis) un Baijesa apvāršņa grafiks (BSP; apakšējais panelis). Zaru krāsa norāda uz lokalizāciju (skat. leğendu), un platums korelē ar aposterioro varbūtību (vērtības $>0,7$ ir norādītas mezglos). BSP $y$ ass norāda uz populācijas izmēru, kas izteikts efektīvās populācijas $(\mathrm{Ne})$ reizinājumā ar paaudzes ilgumu gados $(\tau)$, iegūtā vērtība ir proporcionāla incidencei [Frost and Volc, 2010]. Sarkanā nepārtrauktā līnija atbilst mediānai, un laukums starp punktētajām līnijām atbilst 95\% HPD robežām. Abi grafiki ir atainoti vienā laika skalā. Taksonu nosaukumi kodē izolēšanas valsti, numuru un laiku. 


\section{DISKUSIJA}

\subsection{Pētījuma pamatgrupa}

Šajā pētījumā tika prospektīvi iekḷauti Latvijas vienīgās terciārā līmeņa bērnu slimnīcas, BKUS, populācija ar dziļāko elpcel̦u infekciju atbilstoši PVO gadījuma definīcijai. Pētījuma veikšanas laikā HRSV diagnostikas standarts BKUS bija IFA tests, kas tika sūtīts uz citu iestādi (LIC laboratoriju), līdz ar to testa rezultāta atgriešanās laiks parasti bija vairākas dienas, un pacientu iekḷaušanas laikā pētījumā nebija zināma IFA atbilde (nevienā no gadījumiem). Pētījumā tika iekḷauti tikai iepriekš veseli bērni ar vecuma kritēriju 2-24 mēnešiem. Tam bija vairāki iemesli: (1) praktiski visi bērni, kas vecāki par diviem gadiem, ir vismaz vienreiz pārslimojuši HRSV; (2) bērniem, kas jaunāki par diviem mēnešiem, elpošanas darbu būtiski ietekmē vairāki faktori; (3) tā paša apsvēruma dēḷ netika iekḷauti pacienti ar hroniskām pavadošām slimībām; (4) ņemot vērā iepriekšējos faktorus, būtu apgrūtināts objektīvs klīniskās gaitas salīdzinājums starp pacientu grupām. Neiznestība, iedzimta sirdskaite un hroniska elpcel̦u saslimšana ir būtiski HRSV infekcijas morbiditātes un mortalitātes riska faktori [Simões and Carbonell-Estrany, 2003], tomēr absolūti lielākā daḷa zīdaiņu ar HRSV infekciju ir bijuši iepriekš veseli, un kontroles pasākumu ieviešanai būtu jābūt primāri vērstai tieši uz š̄is grupas pirmreizēju saskari ar HRSV [Anderson et al., 2013; Hall et al., 2009]. Slimības ilgums vairāk kā 10 dienas tika izvēlēts par izslēgšanas kritēriju, jo HRSV RNS deguna sekrētos ir detektējama vidēji līdz 11 dienai [von Linstow et al., 2006]. Pētījuma laiks trīs respiratoro infekciju sezonas tika uzskatīts par pietiekamu, lai noteiktu galveno antigēno grupu mainību.

\subsection{HRSV diagnostika}

Pētījuma vajadzībām tika izstrādāta jauna klīnisko paraugu savākšanas metode virusologiiskajām analīzēm BKUS - NFA. Lietojot vienādus virālās diagnostikas testus, NFA paraugu lietošana var palielināt jutību pat par 30\%, salīdzinot ar deguna iztriepi [Macfarlane et al., 2005]. 
Pēdējo gadu laikā šūnu kultūra, kas agrāk tika uzskatīta par respiratoro vīrusu diagnostikas zelta standartu, daudzviet ir nomainīta ar nukleīnskābju amplifikācijas testiem, kuru jutīgums sasniedz pat 100\% [Henrickson et al., 2007]. Šajā pētījumā izstrādātais RTPCR diagnostikas protokols ļauj ne tikai precīzi diagnosticēt HRSV infekciju klīniskajos paraugos, bet ir arī ērti izmantojams ātrai HRSV grupu diferencēšanai. Virālā RNS no NFA paraugiem tika izmantota par pamatu, uz kā tika veikta cDNS sintēze ar praimeri, kas atbilda abām HRSV grupām. Šie paraugi tika tālāk skrīnēti PCR ar grupu specifiskiem praimeriem. Šādā veidā ar RT-PCR metodi HRSV nukleīnskābes klātbūtne tika noteikta sešiem paraugiem, kas ar IFA tika traktēti kā negatīvi. Divos gadījumos RT-PCR nediagnosticēja HRSV IFA pozitīvos paraugos. Tas varētu būt skaidrojams ar RNāžu klātbūtni, PCR inhibitoru klātbūtni vai RNS nestabilitāti [Gilbert et al., 1996], kas bieži novērojama atkārtoti sasaldētos un atkausētos paraugos. Šajā pētījumā paraugi tika sasaldēti-atsaldēti divos ciklos: respiratorie paraugi tika iesaldēti pēc savākšanas; atsaldēti, lai izdalītu RNS, kas atkal tika iesaldēta līdz cDNS sintēzei. Lai arī sasaldēšanuatkausēšanu līdz trīs reizēm pieļauj RNS izolācijas komplekta ražotāja protokols (QIAamp Viral RNA Mini Kit, QIAGEN), nav izslēgta tās negatīvā ietekme. Turpmākie darba etapi tika veikti uz cDNS bāzes, kas ir ievērojami stabilāka. Galvenā RT-PCR priekšrocība, salīdzinot ar IFA, ir spēja diagnosticēt vīrusa nukleīnskābes klātbūtni arī ļoti zemā koncentrācijā, kā arī detektēt replicēties nespējīgu vīrusu. Iespēja, ka RT-PCR dotu viltus pozitīvu atbildi, ir atkarīga no praimeru specifiskuma, bet kopumā ir vērtējama kā ļoti zema [Liolios et al., 2001]. N̦emot vērā visus šos apsvērumus, 95,2\% jutība un 91,2\% specifiskums, salīdzinot ar IFA kā ,zelta standartu”, tika uzskatīiti par pietiekošiem pētnieciskajiem darba uzdevumiem.

HRSV epidemiologiija Eiropas valstīs ir samērā konstanta. Hospitalizētiem bērniem zem divu gadu vecuma ar dziḷāko elpceḷu infekciju, HRSV ir ierosinātājs 42-45\% gadījumu [Simões and Carbonell-Estrany, 2003]. Šī pētījuma populācijā rezultāti bija līdzīgi - HRSV izraisīja 42,5\% dzị̄āko elpceļu infekciju. Zemāks HRSV izolācijas biežums 2009./2010. sezonā ir izskaidrojams ar gripas vīrusa A H1N1 pandēmiju [Nikiforova et al., 2011]. 


\subsection{HRSV sezonalitāte}

HRSV sezonālā aktivitāte Latvijā konstanti sākās vēlāk ziemā un ieilga pavasarī (janvāris - aprīlis), salīdzinot ar vidējo sezonālo aktivitāti (decembris - februāris) ziemel̦u puslodē [Bloom-Feshbach et al., 2013], bet bija līdzīga novērojumiem Krievijā [Tatochenko et al., 2010] un bienālajām „vēlajām” sezonām, kas aprakstītas vairākās Eiropas valstīs - Zviedrijāa, Somijā, Vācijā, Šveicē, Austrijā un Horvātijā [MlinaricGalinovic et al., 2012; Reyes et al., 1997]. Latvijā HRSV sezonas bija monofāziskas, un trīs aplūkotajās sezonās to sākums un beigas lielā mērā sakrita. Ģeogrāfiskās HRSV sezonalitātes atšķirīibas nav labi izskaidrotas, bet, domājams, ir saistītas ar lokāliem klimatiskajiem un cilvēku sociāli-kulturālajiem aspektiem [Stensballe et al., 2003].

Latvijā HRSV epidemioloğiskie un slimības sloga dati nav zināmi. Slimību profilakses un kontroles centra (SPKC) Epidemiologijas bil̦etenā „Pārskats par akūto augšējo elpceļu infekciju (AAEI) un gripas izplatību Latvijā" tiek norādīts kopējais HRSV pozitīvi testēto paraugu skaits LIC laboratorijā bez atsevišksi izdalītiem citiem epidemioloǵiskajiem parametriem. Ši pêtījuma (88 HRSV pozitīvi paraugi) un SPKC 2009.-2012. sezonu kumulatīvo datu (1297 HRSV pozitīvi paraugi; http://www.spkc.gov.lv/) salīdzinājums ir dots 4.1. attēlā [Nikiforova un Kantsone, 2011; Nikiforova et al., 2010; Nikiforova and Pulmane, 2012]. 


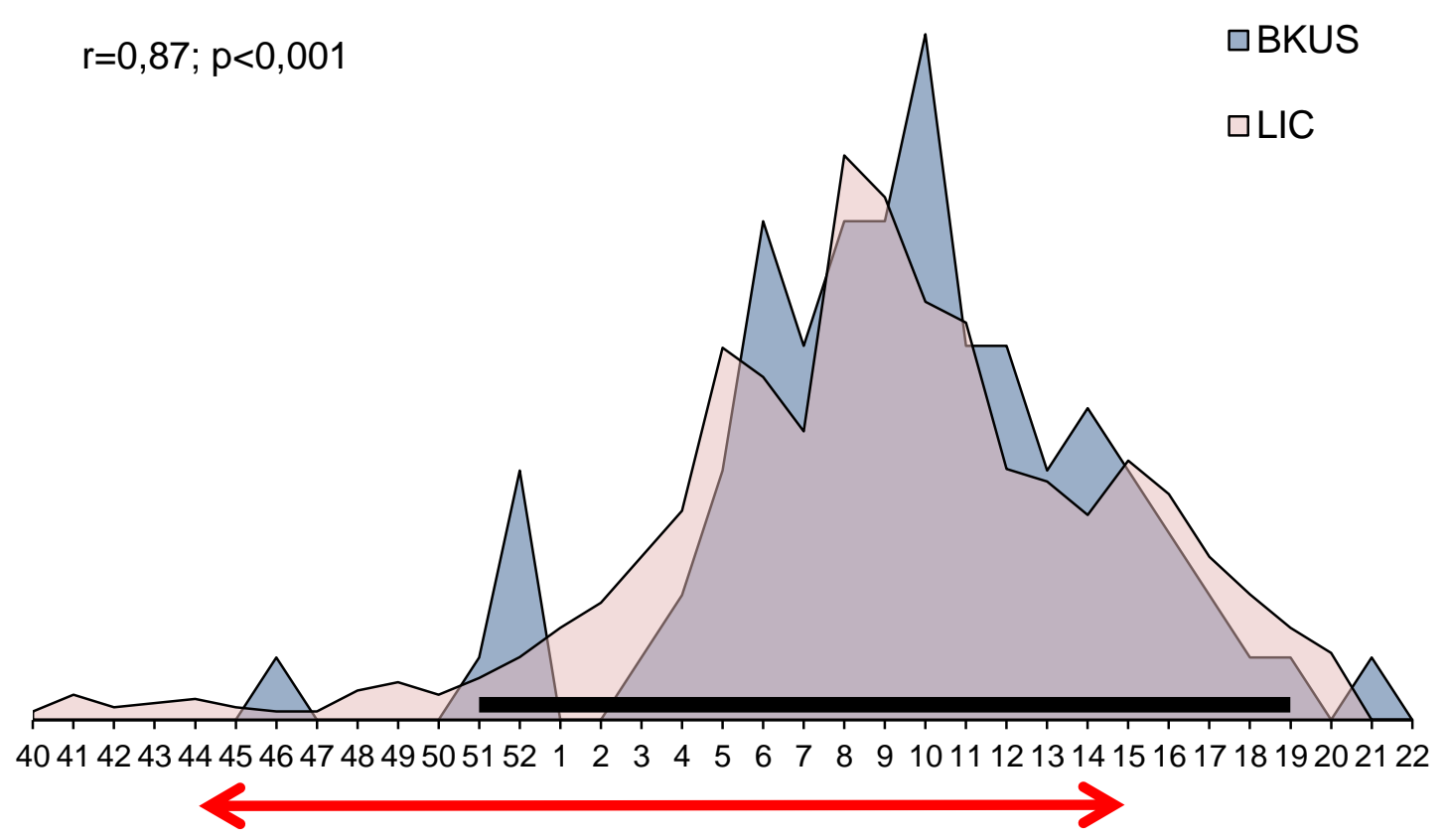

4.1. att. Sezonalitātes datu salīdzinājums ar Slimību profilakses un kontroles centra datiem Normalizētas novēroto datu histogrammas attēlo relatīvos HRSV pozitīvo paraugu sadalījumu blīvumus vienā skalā. Uz $x$ ass attēlotas gada nedēlas. LIC - SIA „Rīgas Austrumu klīniskā universitātes slimnīca” stacionāra „Latvijas Infektologijas centrs” laboratorijas dati; BKUS - š̄ pētījuma dati. Ar biezo melno līniju norādīts kopējais HRSV epidemiolog̣iskās aktivitātes periods trīs sezonu laikā šajā pētījumā (51. - 19. nedēḷa). Ar sarkano bultu norādīts efektīvais palivizumaba profilakses periods, ja tā aplikācija ir balstīta uz pašreizējām

ASV vadlīnijām, pieṇemot, ka tā efekts ilgst 45 dienas pēc pēdējās injekcijas [American Academy of Pediatrics Committee on Infectious Diseases, 2009; Panozzo et al., 2010].

Pacientu skaita sadalījums pa nedēḷām starp šīm divām datu kopām labi korelēja $(\mathrm{r}=0,87 ; \mathrm{p}<0,001)$. Pēc SPKC datiem atsevišķi HRSV pozitīvi paraugi tiek detektēti jau sākot no 40. nedēḷas, tomēr pamatā aktivitāte $(-2 \mathrm{SD}$ līdz $+2 \mathrm{SD})$ bija līdzīgā kā šajā pêtījumā - no 50. līdz 20. nedēḷai, ar nedaudz agrāku pịķi 8. nedȩ̣̄ā (moda), bet vienādu mediānu (10. nedēḷa). HRSV sezonas garums 21 nedēḷa atbilst globālajiem datiem [BloomFeshbach et al., 2013].

Palivizumaba profilakse būtiski samazina hospitalizācijas biežumu gan augsta riska, gan citādi veseliem zīdaiņiem HRSV sezonas laikā. Tomēr neviens randomizēts kontrolēts pētījums nav uzrādījis, ka tas samazinātu mirstību, un arī ekonomiskais ieguvums, ņemot vērā tā lielās izmaksas (Latvijā aptuveni LVL 5000 sezonā uz pacientu; http://www.zva.gov.lv/), nav viennozīmīgs [American Academy of Pediatrics Committee on Infectious Diseases, 2009]. Latvijā nav ieviestas valsts līmeña palivizumaba pielietošanas vadlīnijas, un tā lietošana lielā mērā balstās uz Eiropas un ASV literatūras datiem. Pēc šī pētỉjuma rezultātiem, kurus apstiprina SPKC dati, palivizumaba pirmā deva 
Latvijas apstākḷos tiek dota $>30$ dienas pirms sezonas sākuma, savukārt $>45$ dienas pēc pēdējās devas joprojām ir vērojama HRSV aktivitāte (4.1. attēls). Vairāk kā piecas devas Amerikas Pediatru akadēmija nerekomendē lietot preparāta lielās dārdzības dēl [American Academy of Pediatrics Committee on Infectious Diseases, 2009]. Tomēr jābūt piesardzīgam, šos datus interpretējot sabiedrības mērogā. Šajā pētîjumā tika analizēti agrīna vecuma stacionēti bērni, no kuriem gandrīz 70\% bija kontakts ar infekciju slimnieku, kas varētu liecināt, ka vecākiem ambulatoriem pacientiem (bērnudārza vecumā) HRSV aktivitāte sākas agrāk. Precizēti dati l̦autu labāk pasargāt augsta riska pacientus un ietaupīt lielās palivizumaba profilakses izmaksas, tādēḷ nepieciešams populācijas mēroga HRSV epidemiolog̣isks pētījums, lai precīzi noteiktu tā sezonalitāti un slimības slogu Latvijā.

\subsection{HRSV klīnisko pazīmju raksturojums}

Š̀̃ pētījuma pacientu kohorta bija salīdzinoši homogēna - 2-24 mēnešus veci, iepriekš veseli bērni, kas stacionēti ar dziḷāko elpceḷu infekciju. Pamatā klīniskās pazīmes atbilda bronhiolīta ainai un gandrīz visiem pacientiem $(>90 \%)$ bija klepus, rinīts un sēkšana. Sezonas laikā HRSV izraisīja vairāk kā 90\% bronhiolītu un 50\% pneimoniju, kas vēlreiz pasvītro šī patogēna lielo nozīmību agrīnu vecuma bērnu morbiditātē.

Salīdzinot ar „ne-HRSV” dziļāko elpcel̦u infekciju, HRSV inficētie pacienti bija jaunāki, viṇiem retāk bija SIRS sindroms, bet biežāk atopiskas slimības gimenes anamnēzē. Vairākos dziḷāko elpceḷu infekcijas etioloǵijas pētījumos HRSV inficētie pacienti ir jaunāki par citas etioloǵijas grupu, piemēram, lielā populāciju pētījuma Gvatemalā vecumu attiecība bija identiska kā šajā pētījumā (6 pret 10 mēnešiem) [Fisher Langley et al., 2013]. Augstā titrā mātes antivielas var pasargāt bērnu no inficēšanās ar HRSV, tomēr to titrs pirmo dz̄ives mēnešu laikā samazinās līdz nepasargājošam līmenim [Brandenburg et al., 1997]. Ir vairākas hipotēzes, kas izskaidro, kāpēc pirmajos dzīves mēnešos bērniem ir paaugstināts risks smagai HRSV izraisītai dziḷāko elpceḷu infekcijai: (i) imūnie mehānismi - III tipa imūnkompleksu veidošanās plaušās starp mātes IgG antivielām un HRSV antigēniem; zems sekretorā IgA līmenis; šūnu mediēta IV tipa imūnā reakcija plaušās; T- 
šūnu neatkarīgie mehānismi, kuros iesaistīti makrofāgi, MIP $1 \alpha^{26}$ un citi citokīni; (ii) fizioloǵiskie mehānismi - šauri elpcel̦i, kuros neliela obstrukcija rada proporcionāli lielākas pārmaiņas šķērsgriezuma laukumā [Sommer et al., 2011]. HRSV asociācija ar astmu ir daudz diskutēta. No vienas puses, pēc smagas HRSV infekcijas bieži novērojamas atkārtotas sēkšanas epizodes un astma, no otras - HRSV infekcijas smagāk izpaužas atopiskiem bērniem. SIRS sindroms „,ne-HRSV” grupā bija biežāk, jo, iespējams, tajā ietilpa arī bakteriālas dabas dziḷāko elpceḷu infekcijas.

Zināmi riska faktori kā vīriešu dzimums un saspiesti dzīves apstākḷi (apdzīvotība) [Simões, 2003] šajā pētījumā nebija saistīti ar lielāku HRSV risku, savukārt citi faktori kā neiznestība, neiznēsāta bērna hroniska plaušu slimība, hemodinamiski nozīmīga iedzimta sirdskaite [Resch et al., 2002], trisomija 21 [Bloemers et al., 2007], neiromuskulāras slimības un imūndeficīts [Resch et al., 2009] pētījuma uzbūves dēl nevarēja tikt izvērtēti.

2006. gadā Amerikas Pediatrijas akadēmija izdeva bronhiolīta ārstēšanas vadlīnijas, kuru galvenais mērķis bija ierobežot resursu izmantošanu, t.i. tās rekomendēja pret rutīnas radiologiskās attēldiagnostikas (pierādījumu līmenis B) un bronhodilatatoru (pierādījumu līmenis B) un glikokortokō̄du (pierādījumu līmenis B) lietošanu [American Academy of Pediatrics Subcommittee on Diagnosis and Management of Bronchiolitis, 2006]. 2011. gadā BKUS tika izstrādātas vietējās bronhiolīta un sadzīvē iegūtās pneimonijas vadlīnijas, kas lielā mērā ir līdzịgas Amerikas vadlīnijām. Šajā pētījumā HRSV izraisītas dziḷāko elpceḷu infekcijas ārstēšana bija resursu ietilpīga - galvenokārt tieši plaši pielietoto krūškurvja rentgenogrammu, inhalējamo $\beta_{2}$ agonistu, glikokortikoīdu un antibiotiku dēḷ. Šīm atšķirībām no starptautiskajām vadlīnijām var būt vairāki skaidrojumi: (i) IFA atbildes laiks bija vairākas dienas, kuru laikā pacientam diagnoze bija neskaidra; (ii) pētījuma laikā BKUS vēl nebija ieviestas bronhiolīta un sadzīvē iegūtās pneimonijas vadlīnijas; (iii) 56,8\% ar HRSV infekciju bija atopiskas slimības gimenes anamnēzē, kas varētu likt domāt vairāk par reaktīvu elpcel̦u slimību; (iv) pētījumā tika iekļauts viss dziḷāko elpcel̦u infekciju spektrs, ne tikai bronhiolīts; (v) pētījumā tika iekl̦auti tikai stacionēti bērni ar smagāku slimības izpausmi. Tomēr pētījumā iekḷautie pacienti bija iepriekš veseli, un klīniskās diagnostikas grūtībām nevajadzēja būt, turklāt vairāk kā 75\% pacientu izrakstīšanas diagnoze bija bronhīts vai bronhiolīts. Šo tendenci būtu nepieciešams pētīt atkārtoti pēc

\footnotetext{
${ }^{26}$ Macrophage Inflammatory Protein $1 \alpha$.
} 
vadlīniju ieviešanas, jo citu valstu pieredze liecina, ka nerekomendēto terapiju lietošana pēc to ieviešanas būtiski nesamazinājās [Johnson et al., 2013].

\subsection{HRSV grupu un genotipu klīniskais raksturojums}

HRSV-pozit̄̄vie paraugi tika analizēti ar HRSV-A un B specifiskiem praimeriem. Š̄̄ metode l̦āva noteikt grupu piederību visiem analizētajiem paraugiem. Metodes specifiskums tika pārbaudīts ar paraugu sekvenēšanu, un visos gadījumos iegūtās sekvences atbilda iepriekš noteiktajai grupai. Abu grupu vīrusi cirkulēja paralēli visās trijās analizētajās sezonās. HRSV-A celmi tika izolēti biežāk, un tie dominēja pirmajās divās pētījuma sezonās. Dažādas grupu cirkulācijas īpatnības ir aprakstītas, tomēr kopumā tās seko noteiktam modelim, kur 1-3 secīgas HRSV-A dominantās sezonas nomaina viena HRSV-B dominanta sezona [Venter et al., 2001; Zlateva et al., 2007]. Iemesls šādai alternējošai cirkulācijai nav līdz galam izpētīts, tomēr, matemātiski modelējot periodisku dominējošās grupas nomaiņu, var izskaidrot ar zemāku saimniekorganisma uzṇēmību pret homologu celmu reinfekciju kā pret heterologu [Sande et al., 2013; White et al., 2005]. Abu vīrusu pịķa aktivitāte noritēja vienlaicīgi, un netika novērota korelācija starp epidemioloǵisko nedēlu un HRSV grupu.

3.5. tabulā dots HRSV-A un B infekciju klīniskais salīdzinājums, bet tā kā 97,7\% izolātu piederēja diviem dominantajiem genotipiem, NA1 un BA-IV, tad būtībā ir salīdzināti šie divi genotipi (izņemot ON1 no kopējās analīzes, rezultāti būtiski nemainījās). Lai analizētu šo genotipu klīnisko nozīmību, kā primārais iznākums tika ņemts hospitalizācijas ilgums, bet KSS kā slimības smaguma mērījums. Nevienā no šiem parametriem abas grupas neatšķ̣īās, tādējādi tika noraidīta darba 2. hipotēze. Iespējams, šajā pētījumā statistiski ticamas atšķirības starp grupām (un genotipiem) netika atrastas, jo tika iekḷauti tikai hospitalizēti pacienti, tādējādi izslēdzot no analīzes mazāk akūtus pacientus. Lai arī katra genotipa ietvaros bija atsevišķi klasteri ar augstām sākumpalaišanas vērtībām (skat. 3.5. un 3.6. attēlu), tie atsevišşi netika analizēti salīdzinoši mazā paraugu skaita dēḷ. 
Līdzīgā veidā Martinello ar kolēgiem analizēja atsevišķu genotipu nozīmi, izmantojot KSS [Martinello et al., 2002]. Šajā pētījumā tika novērots, ka GA3 genotipa vīrusi izraisa statistiski ticami smagāku infekciju, salīdzinot ar GA2 un GA4, bet šādas atšķirības netika novērotas starp galvenajām grupām, A un B. Turklāt pēdējos gados pasaulē no šiem genotipiem turpina cirkulēt tikai GA2 [Houspie et al., 2013]. Diagnosticējot HRSV-A un B grupas pēc reakcijas ar monoklonālajām antivielām, gan Volšs ar kolēgiiem, gan Imazs ar kolēǵiem konstatēja, ka smagāka infekcija bija pacientiem ar A grupas vīrusu infekciju [Imaz et al., 2000; Walsh et al., 1997], līdzīgi kā Trans ar kolēgiem Vjetnamā, lietojot PCR [Tran et al., 2013]. Liela mēroga multicentru pētījumā neatliekamās palīdzības nodaḷās ASV, iekļaujot vairāk kā 4000 bērnu ar elpceḷu infekcijām, Džafrijs ar kolēgiem konstatēja, ka HRSV-A pacienti biežāk tiek hospitalizēti (47,7\% pret 35,8\%; p<0,001), bet hospitalizētie HRSV-A pacienti retāk saņem antibiotikas $(32,4 \%$ pret 47,8\%; p<0,001) [Jafri et al., 2013]. Tas ir pagaidām lielākais šāda rakstura pētījums ar vislielāko statistisko atbalstu. Pretēji tam Hornslets secināja, ka HRSV-B ir asociēts ar smagāku slimības gaitu [Hornsleth, 1998]. Visbeidzot ir vairāki pētījumi, kur atšķirības starp HRSV grupām un atsevišşiem genotipiem netika novērotas [Kneyber et al., 1996; McIntosh et al., 1993; Wang et al., 1995; Zhang et al., 2010]. Pašreizējais pierādījumu līmenis nȩ̣auj pieņemt klīniski nozīmīgus lēmumus, balstoties uz HRSV genotipisko analīzi, vai koncentrēties uz viena konkrēta genotipa ierobežošanu. Tāpat ir skaidrs, ka, lai arī HRSV-A izraisa smagāku slimību, efektīvai vakcīnai ir jābūt pasargājošai pret abu grupu infekcijām.

\subsection{HRSV celmu molekulārā analīze}

2009./2010. gadu respiratoro infekciju sezonas HRSV paraugiem tika sekvenēts pilna garuma l̦oti variablais $G$ gēns, bet nākamo divu sezonu izolātiem tikai HVR2 segments. HVR2 ir ideāli piemērots molekulārās epidemiologijas pētījumiem, jo tā mainība salīdzinoši nelielā genoma fragmentā (mazāk kā 2\% no kopējās genoma sekvences) ataino kopējo vīrusa mainību [Rebuffo-Scheer et al., 2011; Tan et al., 2012]. Visas unikālās analizēto paraugu sekvences tika reǵistrētas GenBank datu bāzē. Vairākas sekvences bija 
identiskas gan Latvijas celmu ietvaros (skat. 3.5. un 3.6. attēlus), gan ar celmiem, kas izolēti dažādās citās pasaules valstīs (skat. 3.6. tabulu). Tas liecina, ka dažiem uzliesmojuma celmiem nav ǵeogrāfisku ierobežojumu un tie var palikt stabili vairākas sezonas pēc kārtas. Tā, piemēram, celms LV/056/10, kurā ietilpa deviņi izolāti, Latvijā cirkulēja 2009./2010. un 2010./2011. sezonās, bet pasaulē tas sastopams jau kopš 2007./2008. sezonas un ir detektēts tik attālās vietās kā Nīderlande un Saūda Arābija (3.6. tabula).

Latvijas un iepriekš publicētas HVR2 sekvences ar noteiktiem genotipiem tika ņemtas par pamatu filoǵenētiskajai analīzei. Katrā grupā bija viens genotips, NA1 grupā A un BA-IV grupā B, kas dominēja visu trīs sezonu laikā. Ļoti līdzīgs genotipu sadalījums tika novērots līdzīgos pētījumos citās valstīs (4.1. tabula, 4.2. attēls). Tādējādi netika noraidīta darba 1. hipotēze. 
$\frac{\sqrt[n]{\frac{3}{3}}}{\frac{7}{4}}$

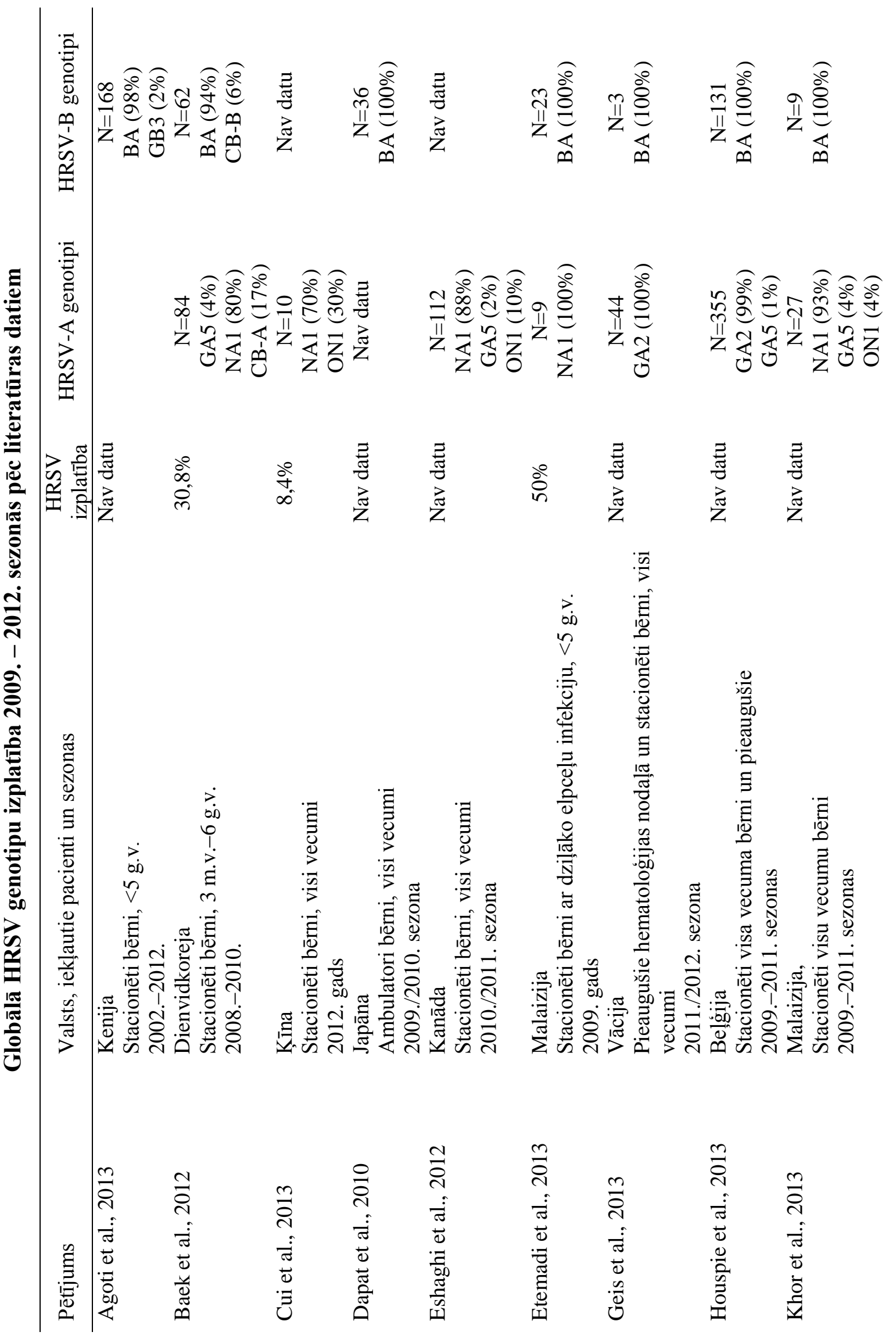




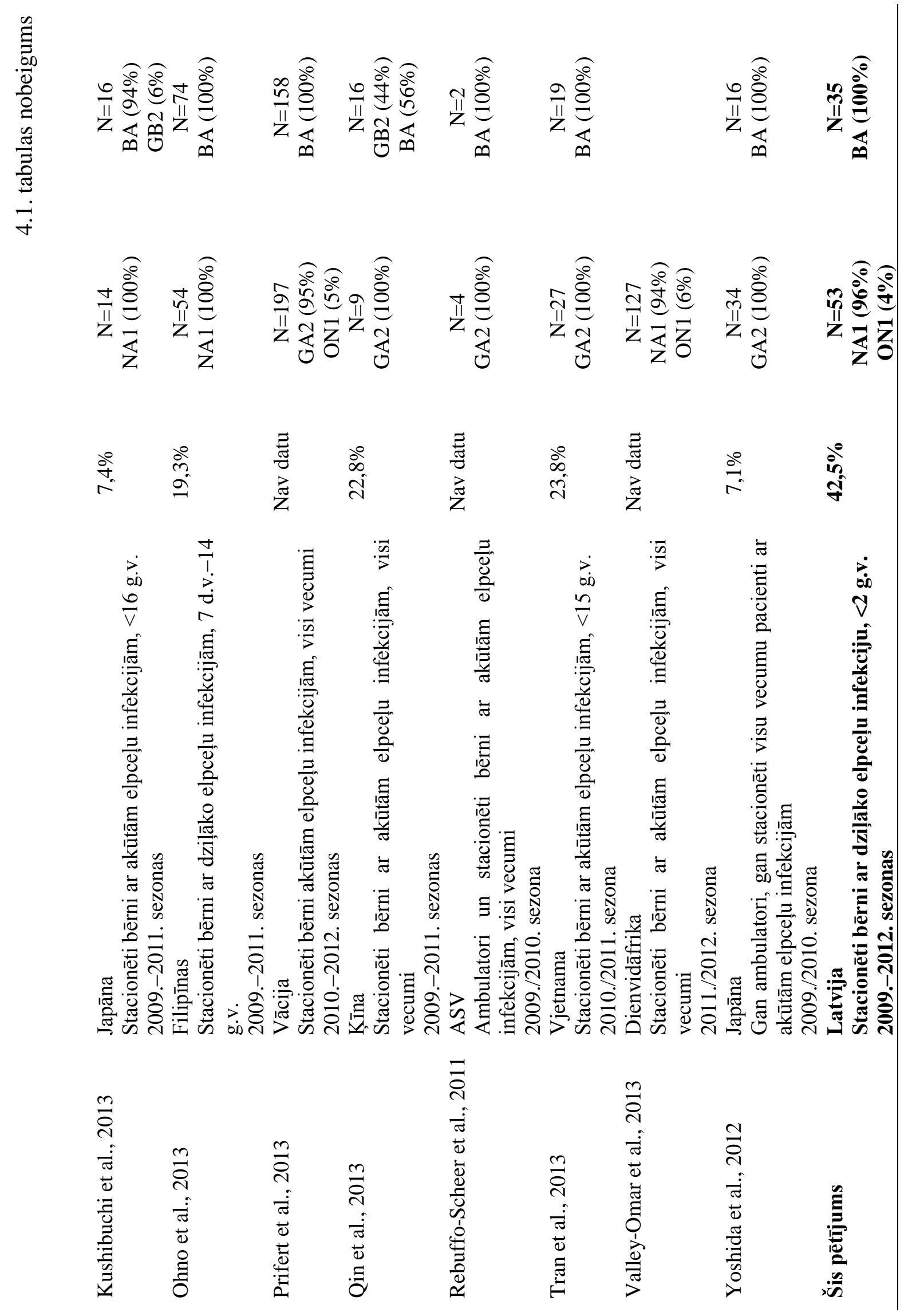




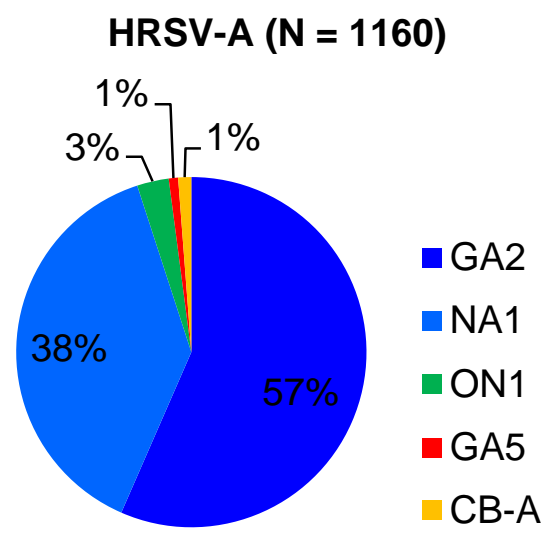

HRSV-B ( $N=734)$

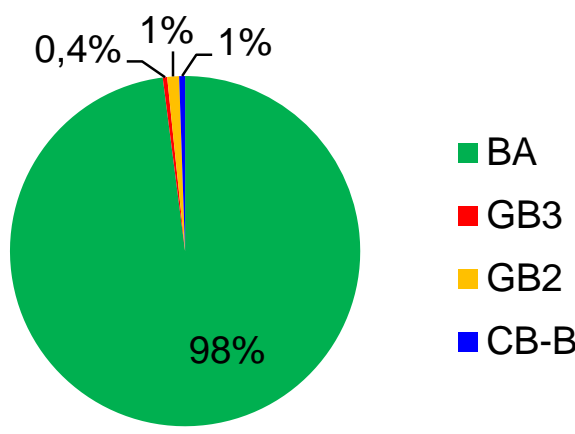

4.2. att. Globālā HRSV genotipu izplatība 2009.-2012. sezonās

4.1. tabulas kopsavilkums, genotipu proporcijas grupu ietvaros, izteiktas procentos. Genotipi GA2 un NA1 vairākos pētījumos netika atsevišksi izdalīti, tādēl abi attēloti vienā krāsā

NA1 genotips pirmo reizi tika aprakstīts Japānā 2004./2005. sezonā [Shobugawa et al., 2009], un turpmākajos gados vairākos HRSV molekulārās epidemiologiijas pētījumos tas noteikts kā dominējošais HRSV-A genotips (skat. 4.1. tabulu). NA1 genotips ir ǵenētiski tuvs GA2 genotipam un netiek viennozīmīgi atsevišksi izdalīts [van Niekerk and Venter, 2011; Yoshida et al., 2012]. To ņemot vērā, GA2 un GA5 ir vairākus gadus bijuši dominējošie genotipi pasaulē, ko apliecina ilgtermiņa HRSV molekulārās uzraudzības pētījumi [Rafiefard et al., 2004; Reiche and Schweiger, 2009; Zlateva et al., 2007]. Genotips GA5 Latvijā netika konstatēts, lai arī ir zināms, ka tas bija sastopams citās valstīs šajā laika periodā [Baek et al., 2012; Eshaghi et al., 2012; Houspie et al., 2013; Khor et al., 2013].

Visām HRSV-B sekvencēm tika konstatēta 60 nt duplikācija G gēnā, kas raksturo BA ǵenētisko līniju [Trento et al., 2003]. Celmi ar šo mutāciju pirmo reizi tika aprakstīti 1999. gadā Buenosairesā (no turienes saīsinājums „BA”), lai gan vēlāka paraugu arhīvu analīze atklāja, ka apmēram pusgadu pirms tam šāda mutācija bija izolātam no Madrides Spānijā. Šì mutācija radās, genotipa GB3 vīrusa RNS polimerāzei antigenomās RNS molekulas sintēzes laikā pārlecot atpakal̦ un vēlreiz transkribējot 60 nt, kas izveidoja stabilu sekundāro RNS struktūru [Trento et al., 2003]. Nākamo 3-4 gadu laikā šādi celmi tika konstatēti visos kontinentos [Trento et al., 2010]. Kopš 2005. gada BA-IV ir visbiežāk 
izolētais HRSV-B genotips pasaulē, kas lielā mērā aizstājis visas pārējās HRSV-B genētiskās līnijas [Agrawal et al., 2009; Houspie et al., 2013; van Niekerk and Venter, 2011; Trento et al., 2010]. Šĩ genotipa parādīšanās sakrīt ar BA vīrusu ātrās izplešanās fāzi, kad to populācijas izmēram bija novērojams eksponenciāls pieaugums [Trento et al., 2010]. Ir aprakstîtas arī vairākas BA-IV apakšlīnijas [Dapat et al., 2010], bet to iekḷaušana molekulārajā analīzē nedeva konsekventus rezultātus.

2012. gadā, nākamajā sezonā pēc sākotnējā apraksta, tika izolēts cits HRSV-A genotips - ON1. Genotipam ON1 raksturīga 72 nt duplikācija G gēnā 3' daḷā. Šis celms parādījās Kanādā 2010./2011. sezonā, kad tas sastādīja 10\% no visiem HRSV-A izolātiem [Eshaghi et al., 2012]. Līdzīga izplatība tika novērota arī nākamajā sezonā Vācijā (10\%) [Prifert et al., 2013], 2012./2013. sezonas sākumā Ķīnā (30\%) [Cui et al., 2013] un 2012./2013. sezonā Japānā (13,4\%) [Tsukagoshi et al., 2013]. 2011./2012. sezonā šajā pêtījumā tika detektēti tikai desmit HRSV-A vīrusi, no kuriem divi (20\%) bija ON1.

Atšķirīibā no lielākās daļas proteīnu, HRSV G proteīns vairāk atšķ̄īās aa nekā nt līmen̄i, kas apstiprina iepriekšejus novērojumus [Cane, 1997, Johnson et al., 1987; Venter et al., 2001]. Tas vēlreiz apstiprina š̄i proteīna strukturālo plasticitāti un spēju panest aa substitūcijas. Starp Latvijas izolātiem tika novērots būtisks $G$ proteīna garuma polimorfisms - no 297 līdz 321 aa (skat. 3.9. attēlu). To ietekmēja sekojoši faktori: (i) visiem NA1 celmiem bija priekšlaicīgs terminācijas kodons un to paredzamā G proteīna sekvence bija 297 aa; (ii) vienīgajam ON1 celmam bija 321 aa gara G proteīna sekvence 24 aa insercijas dēḷ; (iii) BA-IV celmiem paredzamie G proteīna garumi bija 310 un 317 aa alternatīvu terminācijas kodonu izmantošanas dēḷ. HRSV-B celmiem ir aprakstīta dažādu atgriezenisku terminācijas kodonu izmantošana, ieskaitot Stop $313 \rightarrow Q$ [Botosso et al., 2009]. Kopā ar „rāmja” insercijām un delēcijām (kā piemēram, $P 159-K 160$, kas tika novērota visos Latvijas izolātos) BA genētiskajām līnijām ir vismaz 13 dažādi proteīna garumi [Houspie et al., 2013; Trento et al., 2010; Zlateva et al., 2007]. Pēdējos gados ir dominējuši izolāti ar 310 aa G proteīnu [Houspie et al., 2013], un, iespējams, pētījuma izskaņā detektētajiem 371 aa garajiem celmiem atgriežas selektīvas priekšrocības. In vitro G proteīna izmēra redukcija ar „rāmja” priekšlaicīgiem terminācijas kodoniem l̦auj vīrusam izvairīties no neitralizācijas ar monoklonālajām antivielām, neizmainot tā infekciozitāti [Rueda et al., 1991]. 
Glikozilācija ir būtisks HRSV antigenitātes faktors, jo tā var gan nomākt, gan pastiprināt antivielu afinitāti [Botosso et al., 2009]. Celmu specifiskās monoklonālās antivielas reaǵē tikai ar glikozilētu G proteīnu [Martinez et al., 1997], tāpēc celmu raksturojums bez glikozilācijas īpašībām ir nepiln̄̄gs. Šajā pētîjumā proteīnu glikozilācija tika prognozēta, izmantojot neirālā tīkla prognozes. Mutācijas, kas radīja tiešu glikozilācijas receptoru nomaiṇu vai samazināja to glikozilācijas iespējamību, bija bieži sastopamas, tādējādi palielinot celmu fenotipisko dažādību. Tomēr, neskatoties uz G proteīna dažādību un garuma polimorfismu, kopējā prolīna/serīna/treonīna proporcija bija stabila (aptuveni 10, 10 un 25\%), saglabājot mucīnam līdzīgās īpašības [Julenius et al., 2005]. Mucīnam līdzīgie reǵioni ir negatīvas RNS saturošo vīrusu bieži izmantots patogenitātes faktors, kuriem raksturīga īpaši ātra evolūcija, saglabājot to funkciju un patogenitāti. Pastāv divas hipotēzes, kas šo fenomenu izskaidro: (i) spēcīgs pozitīvās selekcijas spiediens un (ii) attīrošās selekcijas trūkums [Wertheim and Worobey, 2009]. Iepriekš veiktos pētījumos imunologisiskās atbildes radīts selekcijas spiediens ir atrasts kā viens no būtiskiem faktoriem, kas virza HRSV ǵenētisko mainību [Cane and Pringle, 1995], tādēl tika veikta arī padziļināta dabīgās atlases analīze. Lai arī kopējā $d N / d S$ attiecība NA1 celmiem bija >1, kas liecina par evolucionāru selekciju, tikai divas pozīcijas atradās zem pozitīivas selekcijas spiediena. Abas šīs vietas ir iesaistītas celma A2 B un T šūnu epitopos [Cane, 1997; Hancock et al., 2003; Norrby et al., 1987] (4.3. attēls).

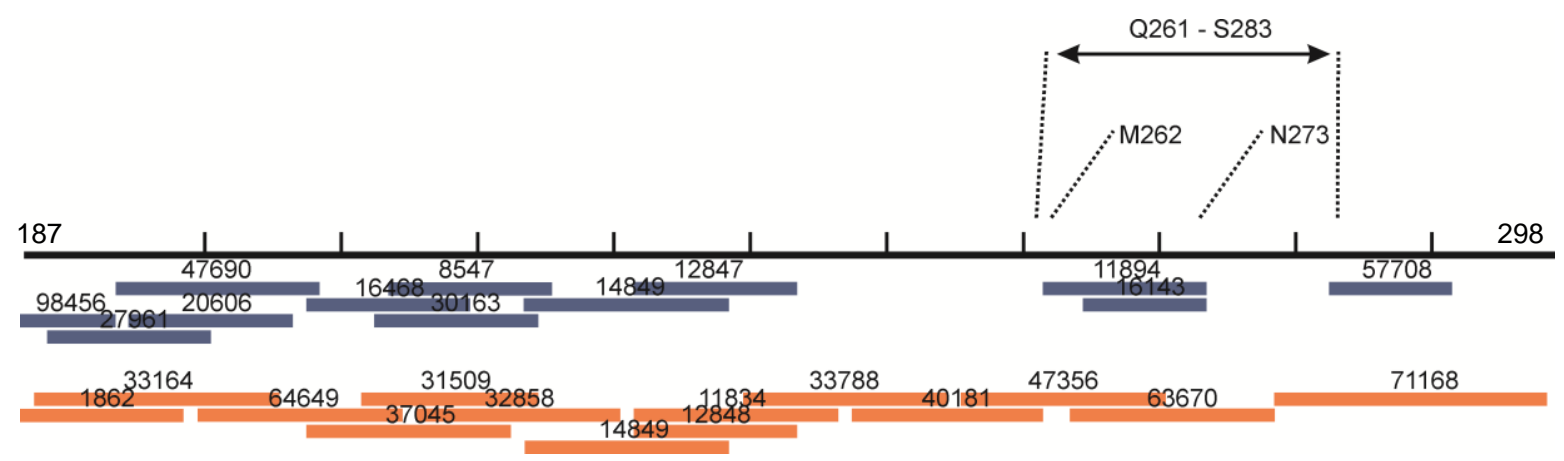

\section{3. att. Celma A2 B un T šūnu epitopu karte}

Karte veidota pēc Imūno epitopu datubāzes meklēšanas rezultātiem (http://www.iedb.org/). Augšejāā diagramma shematiski attēlo celma A2 G proteīna aminoskābju pozīcijas no 187-298. İpaši atzīmētas Latvijas HRSV-A celmu pozitīvās selekcijas vietas un reǵions Q261-S283 (skat. tekstā). B šūnu epitopi norādīiti zilā krāsā, T šūnu epitopi - oranžā. Cipari norāda epitopu datubāzes identifikācijas numurus. 
Šì atradne nav konsekventa dažādos pētījumos, piemēram, M262 un N273 tika arī prognozēti [Eshaghi et al., 2012; Houspie et al., 2013; Kushibuchi et al., 2013; Yoshida et al., 2012; Zlateva et al., 2004], bet netika apstiprināti [Botosso et al., 2009; Tan et al., 2012], lietojot līdzīgu metodolog̣iju kā šajā pētījumā. BA-IV celmiem bija vērojama lielāka dažādība, ko mazāk ietekmēja pozitīvās selekcijas spiediens - kopējā $d N / d S$ attiecība bija 0,45. Divi pozit̄ivi selekcionētie kodoni, L219 un T270, ir iepriekš ziņoti [Botosso et al., 2009; Kushibuchi et al., 2013; Zlateva et al., 2005], kamēr citi kodoni (142, 227, 235, 258, $259,311)$, kas šajos pašos pētījumos izrādījās zem pozitīvās selekcijas spiediena, bija konservatīvi Latvijas sekvencēs (skat. 3.10. attēlu). Šāds konsekvences trūkums skaidrojams ar vairākiem faktoriem. Šajā pētījuma tika analizēts tikai viens genotips abās HRSV grupās. Citos pētījumos, kuros novērojumi veikti pat 10 un vairāk gadus, tika iekḷauti citi tobrīd aktīvi cirkulējoši genotipi, kā arī jau izmirušas genētiskās līnijas. Šādas atškirīibas varētu arī rasties celmiem adaptējoties dažādu saimnieka organismu populāciju imunitātes līmeņiem. Visbeidzot, tas var norādīt arī uz pozitīvās selekcijas trūkumu un vīrusa evolucionēšanu atslābinātas attīrošās selekcijas apstākḷ̆os, t.i. HVR2 segments, saglabājot mucīnam līdzīgās īpašības, nav pārāk ierobežots savā mainībā [Wertheim and Worobey, 2009].

\subsection{HRSV celmu globālā diseminācija}

Kopš sākotnējā apraksta Kanādā, ON1 celmi ir izolēti vairākās pasaules vietās gan no bērniem un veciem ļaudīm [Lee et al., 2012], gan no pacientiem ar intrahospitālu infekciju [Valley-Omar et al., 2013], kā arī ir pieejama tā pilna genoma sekvence [Lee et al., 2012]. ON1 veido atsevišşu klasteri, arī genotipējot pēc F gēna, kas apstiprina, ka tas pieder atsevišķi izdalāmai ǵenētiskajai līnijai [Eshaghi et al., 2012]. Priferta ar kolēǵiem konstatēja asociāciju starp šo genotipu un stacionēšanu intensīvās terapijas nodalıā [Prifert et al., 2013]. Tomēr šī asociācija pagaidām nav citur validēta. Šajā pêtījumā ON1 pacientiem bija vidēji smagas dziḷāko elpceļu infekcijas, un, lai arī vienam no pacientiem hipoksēmijas dēl dažas dienas bija nepieciešama skābekḷa inhalācija, viniiem nebija nepieciešama stacionēšana intensīvās terapijas nodą̧ā. Ešagī ar kolêgiem izvirzịja hipotēzi, 
ka 72 nt duplikācija radusies, RNS polimerāzei pārlecot atpakaļ, vietā, kur atrodas 7 nt atkārtojums un sekundārās RNS struktūras cilpa [Eshaghi et al., 2012]. Tā ir šobrīd lielākā aprakstītā dabīgā insercija G gēnā. Šādas mutācijas ir retas un ir ļoti maz ticams, ka tās varētu rasties vienlaicīgi dažādās vietās neatkarīgi. Līdz ar to tās ir iespējams izmantot kā „dabīgu marķieri”, lai rekonstruētu HRSV celmu disemināciju [Trento et al., 2010]. HRSV izplatības rekonstrukcija, izmantojot stabilus genotipus kā, piemēram, GA2, ir apgrūtināta, jo to ietekmē izolēšanas laika jaucējfaktors - dažādās valstīs pētījumi tiek veikti dažādos laikos, un rodas iespaids par temporāli-ǵeogrāfisku asociāciju [Katzov-Eckert et al., 2013].

Šajā pētījumā ir pirmo reizi aprēķināts ON1 evolūcija ātrums, populācijas dinamika un diskrētā filoǵeogrāfiskā analīze, balstoties pasaulē izdalītajām sekvencēm laika periodā no 2010. gada decembra līdz 2013. gada jūnijam. Aprēķinātais ON1 evolūcijas ātrums HVR2 segmentā $\left(7,92 \times 10^{-3} \mathrm{nt} /\right.$ pozīcijā/gadā) bija ievērojami lielāks par iepriekš ziṇotajiem aprēksiniem, balstoties uz pilna HRSV-A genoma sekvencēm $\left(6,47 \times 10^{-4}\right)$ vai pilna garuma G gēna sekvencēm $\left(2,22 \times 10^{-3}\right)$ [Tan et al., 2012]. Šis temps ir arī lielāks kā evolūcija citu HRSV-A un B genotipu HVR2 segmentā $\left(3,6-4,7 \times 10^{-3}\right)$ [Kushibuchi et al., 2013; Tan et al., 2012], kā arī vismaz decimālo pakāpi lielāks par citu paramiksovīrusu virsmas glikoproteīnu evolūcijas ātrumiem [Mizuta et al., 2011; Saitoh et al., 2012]. Tas, iespējams, liecina par atslābinātu attīrošo selekcijas spiedienu, kas darbojas duplicētajā reǵionā [Wertheim and Worobey, 2009].

ON1 demogrāfiskā vēsture līdz šim ir bijusi ievērojami savādāka kā BA genotipam, kam pēc 60 nt duplikācijas G gēnā pirmajos desmit gados bija vērojama populācijas izplešanās [Trento et al., 2010]. Lai arī efektīvās ON1 populācijas izmērs pirms 2012./2013. sezonas sākuma samazinājās, šie dati var mainīties, kad kḷūs pieejamas jaunas sekvences. Iespējams, ka tāpat kā BA genotipiem, papildus duplikācijai ir nepieciešamas citas mutācijas, lai panāktu optimālu vīrusa adaptāciju replikācijai. Mehānisms, kā 20-aa insercija BA celmiem rada selektīvas priekšrocības, nav zināms. Iespējams, tā mainīja G proteīna antigēnās īpašības, l̦aujot izvairīties no iepriekš esošajām neitralizējošajām antivielām cilvēku populācijā, un turpmāk novērotais antigēnais drifts vēl vairāk uzlaboja vīrusa pielāgošanos [van Niekerk and Venter, 2011; Trento et al., 2010]. Jāpiezīmē, ka, lai arī BA vīrusi ir gandrīz pilnībā aizstājuši citas HRSV-B ǵenētiskās līnijas, to izraisītā slimība nav smagāka un HRSV-A un B populāciju izmēri saglabā līdzīgas proporcijas kā 
pirms BA parādīšanās [Katzov-Eckert et al., 2012]. ON1 gadījumā, duplikācijas reǵions satur vairākus $\mathrm{B}$ un $\mathrm{T}$ šūnu epitopus [Cane, 1997] un maina $\mathrm{G}$ proteīna $O$ - un $N$ glikozilācijas īpašības (4.2. un 3.8. attēli). Divu gadu laikā vairāki izolētie ON1 vīrusi arī ir uzrādījuši antigēno driftu duplicētajā segmentā, kas vairs nav tieša sākotnējās sekvences kopija (4.4. attēls).

Canada 67-1210 2011 Japan 65402012.7 Japan 65772012.8 Japan 65622012.8 Italy 122212012.2 Italy 162232012.3 Italy 101622012.2 Italy 022532012 Germany 145762012.4 SouthAfrica 0012012.2 Germany 163972012.4

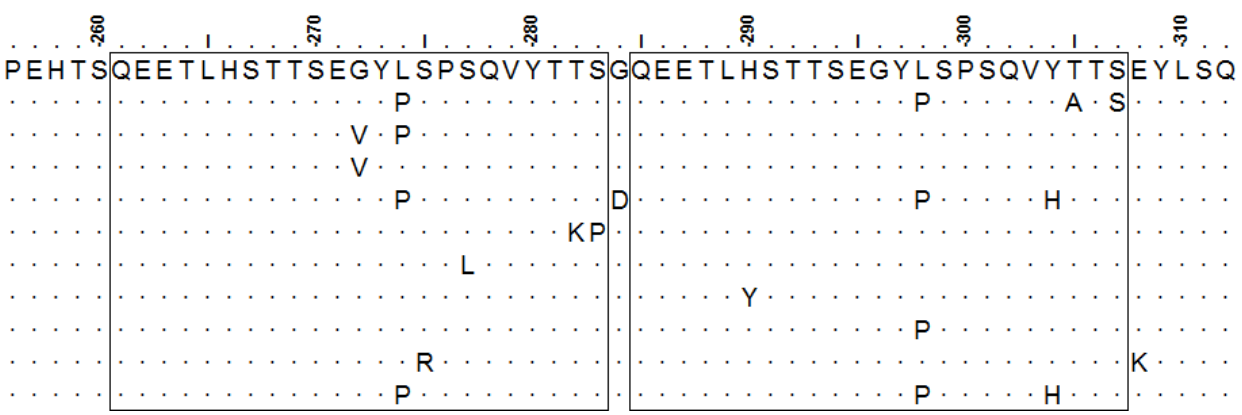

4.4. att. Aminoskābju izkārtojums genotipa ON1 duplicētajam segmentam

Duplikācija norādīta ar taisnstūri. Pasaules izolātu salīdzinājums dots pret sākotnēji aprakstīto celmu ON671210A (GenBank pieejas kods JN257693). Iekḷautas tikai sekvences, kas neatkārtojās aplūkotajā fragmentā.

Diskrētā filoǵeogrāfiskā analīze uzrādīja divas galvenās ON1 transmisijas likumsakarības [Holmes et al., 2008]: (i) viḷnveida izplatīšanās no Kanādas caur Itāliju uz pārējām pasaules valstīm ar noteiktu virzienu no rietumiem uz austrumiem un (ii) gravitācijas efekts, kur, domājams, sekojot cilvēku pārvietošanās maršrutiem, vīruss no „distāliem” reǵioniem atkārtoti nonāca Vācijā (3.12. un 4.5. attēli). 


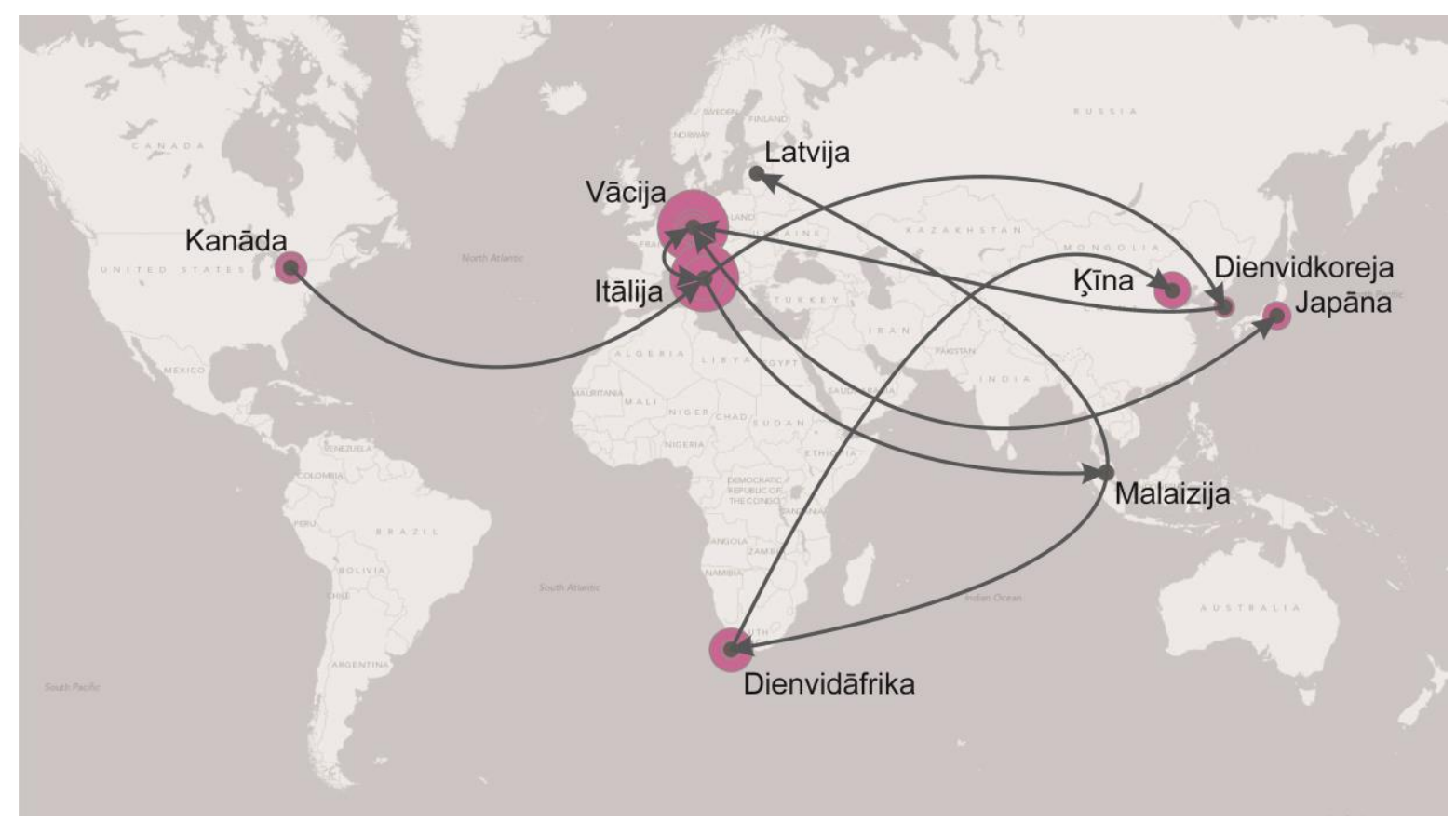

\section{5. att. Genotipa ON1 iespējamie migrācijas cel̦i}

Bultas norāda MCC filoǵeoǵenētiskā koka zarus (skat. 3.12. attēlu), kur notikušas pārejas starp lokalizācijām. Krāsainie apḷi ataino lokalizācijas 95\% HPD robežas.

ON1 izplatības rekonstrukcijā vairākām lokalizācijas pārejām trūka statistiskā nozīmība, tomēr šo hipotēzi atbalsta vairāki papildus pierādījumi. Pirmkārt, visiem ON1 genomiem, kas pieejami GenBank, ir arī $E 232 \rightarrow G$ un $T 253 \rightarrow K$ mutācijas (globālo celmu izkārtojumu nesen publicēja Cui ar kolēǵiem) [Cui et al., 2013]. Kad NCBI-BLAST serverī tika meklētas ON1 proteīna sekvences ar izgrieztu duplicēto segmentu, neviens no meklēšanas rezultātiem šīs divas mutācijas nesaturēja, tomēr $E 232 \rightarrow G$ bija aprakstīta vienam no Kanādas NA1 celmiem, kas tika izolēts vienā pētījumā ar ON1, kas varētu liecināt par zināmu pēctecību. Otrkārt, cits NA1 celms (LV/043/12) arī tika izolēts Kanādā un nākamajā sezonā Itālijā, Vācijā un Latvijā (3.6. tabula). Treškārt, aprēķinātais tMRCA (2010. gada augusts) labi sakrīt ar Ešagī un kolēǵu prognozēm, ka šis genotips ir radies dažus mēnešus pirms 2010./2011. ziemas [Eshaghi et al., 2012]. Ceturtkārt, ticamākie vīrusa izplatīšanās ceḷi atbilda galvenajiem cilvēku starpkontinentālajiem pārvietošanās cel̦iem. Lai arī šo argumentu nevar attiecināt uz Malaizijas-Latvijas iespējamo ON1 migrācijas ceļu un tam nebija arī statistiskā atbalsta, iepriekš ir novērota ǵenētiska radniecība starp šajā pētījumā izolēto NA1 celmu LV/012/10 un celmiem no citas Okeānijas valsts - Filipīnām [Ohno et al., 2013]. Tikai vienam no šī pētījuma ON1 
pacientiem bija fiksēta ceļošanas anamnēze, un ir zināms, ka šis pacients nebija ceļojis ārpus Latvijas. Kopumā netika noraidīta darba 3. hipotēze, jo ticami tika rekonstruēta genotipa ON1 globālā izplatība.

Cukagoši ar kolēgiem ON1 tMRCA aprēķināja 2001. gadā [Tsukagoshi et al., 2013], tomēr šis laiks liekas pārāk sens, jo HRSV molekulārās uzraudzības pētījumi aktīvi norisinās vairākās pasaules valstīs, un 72 nt duplikācija pirms 2010. gada nav konstatēta. Sākotnējam ON1 izolātam no Kanādas bija precīza 72 nt duplikācija un vēlāk izdalītie izolāti uzrādīja, lai arī vāju, tomēr noteiktu ǵenētiskās mainības signālu laikā (3.11. attēls) un vairs nesaglabāja precīzu duplikācijas kopiju (4.4. attēls). Iespējams, šāda atšksirība radās, jo Cukagoši noteica tMRCA starp ON1 izolātiem un NA1 references celmu NG-01604 (izolēts 2004. gada 28. oktobrī), un rezultāts būtu savādāks, ja analīzē tiktu iekḷauti nesenāki NA1 celmi.

Katcova-Ekerta ar kolēgiem rekonstruēja vairāku citu populāru genotipu disemināciju pasaulē [Katzov-Eckert et al., 2013]. Pēc autores datiem genotips GA2 sākotnēji parādījās Okeānijā un ar augstu ticamību pēc tam izplatījās uz Eiropu un Dienvidameriku, turklāt Eiropa kalpoja kā ,gravitācijas” centrs, no kura šis genotips izplatījās uz pārējām pasaules daḷām. Arī genotips GA5, lai arī tā izcelsmes reǵions nav zināms, galvenokārt cel̦oja uz un no Eiropas. BA apakšgrupa izcēlās no Dienvidamerikas, no kurienes tā izplatījās uz Eiropu un turpināja aktīvi migrēt starp Ziemel̦ameriku un Dienvidameriku, savukārt Eiropa atkal bija starpposms izplatībai uz pārējo pasauli.

\subsection{Pētījuma datu interpretācijas ierobežojumi}

Šim pētījumam ir vairāki ierobežojumi, kas liek piesardzīgi vērtēt gan tā klīniskos, gan molekulāros rezultātus. Pirmkārt, nebija iespējams validēt pielietoto diagnostikas metodi ar virusologijas zelta standartu - šūnu kultūru, tās dārdzības dēḷ. Otrkārt, pacientu iesaiste pētījumā bija atkarīga no pētnieku pieejamības (kopā pacientu iesaistē piedalījās četri pētnieki, caurmērā, sezonas laikā pieejami bija divi), kas lielā mērā bija ierobežota ar darbadienām, t.i. nebija pilnībā sistematizēta. Treškārt, lai arī BKUS ir terciārā līmeņa slimnīca, ir skaidrs, ka lielākā pacientu daḷa atbilda sekundārajam līmenim, turklāt daḷa 
Rīgas pacientu nonāca BKUS citā novietnē - „Gaiļezers”. 13,4\% pacientu kā dz̄̄vesvietu atzīmēja lauku teritoriju, bet reg̣ions sīkāk netika izdalīts. Līdz ar to nevar precīzi aprēķināt, kāda Latvijas bērnu populācijas daļa tika pētījumā iekḷauta, un nav iespējams aprēķināt populācijas mēroga datus. Neskatoties uz šiem trūkumiem, sezonalitātes datus varēja labi validēt ar SPKC pieejamo informāciju, un pētījums saglabā savu nozīmi kā viena terciāra līmeņa slimnīcas datu analīze.

Molekulāro datu interpretāciju ierobežo to informātiskais raksturs. Lai arī veiksmīgi tika sekvenēti piln̄̄gi visi HRSV pozitīvie paraugi (kas bieži ir bijis apgrūtinājums līdzīgos pētījumos citur, skat. 4.1. tabulu), proteīnu analīze (glikozilācija, pozitīvās selekcijas vietas u.c.) tika balstīta uz matemātiskiem aprēķiniem, nevis tiešiem proteomikas vai imunoloǵiskiem datiem. Genotipa ON1 filodinamiskie un filoǵeogrāfiskie aprēķini balstījās uz molekulārā pulksteņa hipotēzi. Lai arī bija statistiski nozīmīga tās klātbūtne, tā tikai daļēji ( $\left.\mathrm{R}^{2}=0,21\right)$ izskaidroja ǵenētiskās atšksirības starp izolātiem (3.10. attēls). RNS vīrusu evolūciju limitē arī strukturāli ierobežojumi kā, piemēram, sekundārā RNS struktūra, kas pārkāpj molekulārā pulksteņa pieṇēmumu [Simmonds and Smith, 1999]. Šie faktori tika kompensēti, aprēķinos lietojot atslābināta molekulārā pulksteņa modeḷa parametru, kas piel̦auj nt substitūciju biežumu variācijas starp ǵenētiskajām līnijām. 


\section{SECINĀJUMI}

1. Pētījuma vajadzībām tika izstrādāta oriǵināla HRSV PCR diagnostikas metode, kas ļāva izškirt arī galvenās grupas HRSV-A un B un, salīdzinot ar IFA testu, uzrādīja $95,2 \%$ jutību un $91,2 \%$ specifiskumu.

2. Ar dziḷāko elpceļu infekcijām stacionētiem bērniem vecumā no 2-24 mēnešiem HRSV bija ierosinātājs 42,5\% gadījumu.

3. HRSV sezonālā aktivitāte tika noteikta no 51. līdz 19. gada nedēlai.

4. Pētījumā netika noteikta saistība starp HRSV genētisko grupu A un B vai atsevišķu genotipu un to izraisīto infekciju klīnisko smagumu (noraidīta darba 2. hipotēze).

5. Pētījumā tika detektēti vairāki gan iepriekš citur izolēti, gan Latvijai unikāli HRSV celmi, kuru molekulārā epidemioloǵija kopumā atbilda globālajām cirkulācijas tendencēm (netika noraidīta darba 1. hipotēze). Glikoproteīna G mainību varēja tikai dalı̄eji izskaidrot ar saimniekorganisma imunologiskās sistēmas radītu selekcijas spiedienu.

6. Pielietojot molekulārā pulksteņa principu Baijesa evolucionāajāa analīzēe, ticami tika rekonstruēta genotipa ON1 globālā izplatība un populācijas dinamika (netika noraidīta darba 3. hipotēze). 


\section{PRAKTISKĀS REKOMENDĀCIJAS}

1. N̦emot vērā biežo izplatīibu stacionētiem bērniem ar dziḷāko elpceļu infekciju tā sezonas laikā, optimālai pacientu kohortēšanai būtu vēlams ieviest HRSV ātrās diagnostikas testu terciārā līmeņa bērnu slimnīcā. Tas, iespējams, ļautu ietaupīt arī HRSV infekciju ārstēšanā nepieciešamos resursus.

2. Valsts specifiskās imūnprofilakses stratēgijas veidošanā būtu jāṇem vērā, ka Latvijā HRSV sezonālā aktivitāte sākas un beidzas vēlāk kā citās Ziemeļu puslodes valstîs un šo valstu rekomendācijas var nederēt Latvijas apstākḷiem. 


\section{AUTORA PUBLIKĀCIJAS UN ZIN̦OJUMI}

\subsection{Publikācijas}

1. Balmaks R, Ribakova I, Gardovska D, Kazaks A. 2013. Molecular epidemiology of human respiratory syncytial virus over three consecutive seasons in Latvia. Journal of Medical Virology doi:10.1002/jmv.23855.

2. Balmaks R, Ribakova I, Gardovska D, Kazaks A. 2013. Molecular epidemiology of respiratory syncytial virus during the 2009-2010 season in Latvia. Archives of Virology 158(5):1089-1092.

3. Eihvalde L, Ansone S, Balmaks R, Ribakova I, Kazāks A, Grope I, Kozlovska L, Livdāne J, Gardovska D. 2012. Viral lower respiratory tract infections in children under 2 years of age in the winter season of 2010/2011 in Children's University Hospital, Riga (Latvia). Lietuvos Bendrosios Praktikos Gydytojas 16(9):612-617.

4. Balmaks R, Kazaks A, Likopa Z, Grope I, Rasnacs O, Gardovska D. 2011. A new tool for molecular monitoring of respiratory syncytial virus in children with lower respiratory tract infections. Riga Stradins University Collection of Scientific Papers 2010:100-105.

\subsection{Ziņojumi kongresos un konferencēs}

1. Balmaks R, Ribakova I, Grope I, Gardovska D, Kazāks A. Molecular epidemiology of respiratory syncytial virus over three consecutive seasons in Latvia. 31st Anual Meeting of the European Society For Paediatric Infectious diseases. Milāna, Itālija, 2013.

2. Ribakova I, Balmaks R, Grope I, Gardovska D, Kazāks A. Respiratorā sincitiālā vīrusa molekulārā epidemiologíja triju sekojošu sezonu laikā. Rīgas Stradiña universitātes Zinātniskā konference, 2013.

3. Ribakova I, Grope I, Balmaks R, Kazāks A, Gardovska D. Apgrieztās transkripcijas polimerāzes ķēdes reakcijas lietojums respiratori sincitiālā vīrusa diagnostikai Bērnu 
klīniskajā universitātes slimnīcā. Rīgas Stradina universitātes Zinātniskā konference, 2012.

4. Balmaks R, Kazaks A, Ribakova I, Rasnacs O, Grope I, Gardovska D. Subgroup characteristics of respiratory syncytial virus during 2009/2010 season in Latvia. 29th Anual Meeting of the European Society For Paediatric Infectious diseases. Hāga, Nīderlande, 2011.

5. Balmaks R, Freivalds J, Gardvoska D, Kazaks A. Molecular monitoring and yeast expression of respiratory syncytial virus structural genes from clinical samples in Latvia during 2009/10 season. Viruses and Cells Gordon Research Conference. Barga, Itālija, 2011.

6. Balmaks R, Kazāks A, Ribakova I, Grope I, Gardovska D. Respiratori sincitiālā vīrusa apakšgrupu raksturojums Bērnu klīniskajā universitātes slimnīcā 2009./2010. gada epidēmiskajā sizonā. Rīgas Stradiņa universitātes Zinātniskā konference, 2011.

7. Balmaks R, Kazaks A, Ribakova I, Grope I, Gardovska D. Circulation of group A and B respiratory syncytial virus in Latvia. 1st Baltic Paediatric Congress. Viḷņa, Lietuva, 2011.

8. Balmaks R, Likopa Z, Grope I, Gardovska D, Kazaks A. Development of a novel PCR diagnostic assay of respiratory syncytial virus in young children with severe disease. 28th Anual Meeting of the European Society For Paediatric Infectious diseases. Nica, Francija, 2010.

9. Balmaks R, Kazāks A, Ribakova I, Grope I, Gardovska D. Respirato sincitiālā vīrusa apakšgrupu raksturojums bērnu klīniskajā universitātes slimnīcā 2009./2010. gada epidēmiskajā sezonā. Rīgas Stradiņa universitātes 9. zinātniskā konference, 2010.

10. Balmaks R, Līkopa Z, Grope I, Gardovska D, Kazāks A. Jauna respiratori sincitiālā vīrusa genotipēšanas metode bērniem ar dziļo elpceļu infekciju. Rīgas Stradinaa universitātes 9. zinātniskā konference, 2010.

11. Līkopa Z, Balmaks R, Celmiņa Dz, Rasnačs O, Grope I, Gardovska D. Respiratori sincitiālā vīrusa (RSV) infekcijas epidemiologiskās un klīniskās īpatnības Bērnu KUS ārstētiem bērniem. Rīgas Stradiņa universitātes 9. zinātniskā konference, 2010. 


\section{PATEICĪBAS}

Vislielākā pateicība maniem darba vadītājiem un skolotājiem Dacei Gardovskai un Andrim Kazākam. Bez Profesores šis darbs nekad nebūtu uzsākts un bez Kazāka novests līdz galam.

Tāpat šis darbs nekādi nebūtu iespējams bez VSIA BKUS 9., bijušās 7. nodaļas un Mikrobiologijas laboratorijas personālu atsaucības. Personīgas pateicības arī Irinai Ribakovai par lielu palīdzību visos pētījuma posmos, Zanei Līkopai un Lotai Ozolai par pacientu iesaisti pētījumā, doc. Renāram Ertam un Oskaram Rasnačam (abi RSU) par palīdzību biostatistikā, doc. Jānim Januševskim (Rīgas Tehniskā universitāte) par konsultācijām Baijesa teorēmā, Jēkabam Januševskim un Annai Jaunbergai par palīdzību grafiskajā noformējumā. Paldies prof. Gregorijam Storčam (Vašingtona Universitātes Medicīnas skola, Sentluisa, ASV) par ieteikumiem un kritiku. Kā arī Ievai Lībietei, kura ar molekulāro bioloǵiju ir saistīta tikai piespiedu kārtā, un pārējai manai ǵimenei, kas ar to nav saistīta nekādā veidā, bet izrādīja sapratni un iecietību. 


\section{IZMANTOTĀ LITERATŪRA}

1. Adams JM. 1941. Primary virus pneumonitis with cytoplasmic inclusion bodies: Study of an epidemic involving thirty-two infants, with nine deaths. JAMA 116(10):925-933.

2. Agoti CN, Gitahi CW, Medley GF, Cane PA, Nokes DJ. 2013. Identification of group $\mathrm{B}$ respiratory syncytial viruses that lack the 60-nucleotide duplication after six consecutive epidemics of total BA dominance at coastal Kenya. Influenza and Other Respiratory Viruses Epub: June 20, 2013. doi: 10.1111/irv.12131.

3. Agrawal AS, Sarkar M, Ghosh S, Chawla-Sarkar M, Chakraborty N, Basak M, Naik TN. 2009. Prevalence of respiratory syncytial virus group B genotype BA-IV strains among children with acute respiratory tract infection in Kolkata, Eastern India. Journal of Clinical Virology 45(4):358-361.

4. American Academy of Pediatrics Committee on Infectious Diseases. 2009. Modified recommendations for use of palivizumab for prevention of respiratory syncytial virus infections. Pediatrics 124(6): 1694-1701.

5. American Academy of Pediatrics Subcommittee on Diagnosis and Management of Bronchiolitis. 2006. Diagnosis and management of bronchiolitis. Pediatrics 118(4):1774-1793.

6. Amirav I, Luder AS, Kruger N, Borovitch Y, Babai I, Miron D, Zuker M, Tal G, Mandelberg A. 2008. A double-blind, placebo-controlled, randomized trial of montelukast for acute bronchiolitis. Pediatrics 122(6):e1249-e1255.

7. Anderson LJ, Dormitzer PR, Nokes DJ, Rappuoli R, Roca A, Graham BS. 2013. Strategic priorities for respiratory syncytial virus (RSV) vaccine development. Vaccine 31, Supplement 2(0):B209-B215.

8. Andrade MA, Hoberman A, Glustein J, Paradise JL, Wald ER. 1998. Acute otitis media in children with bronchiolitis. Pediatrics 101(4):617-619.

9. Ater D, Shai H, Bar B-E, Fireman N, Tasher D, Dalal I, Ballin A, Mandelberg A. 2012. Hypertonic saline and acute wheezing in preschool children. Pediatrics 129(6):e1397e1403.

10. Baek Y, Choi E, Song M-S, Pascua P, Kwon H-i, Park S-J, Lee J, Woo S-I, Ahn B-H, Han H-S, Hahn Y-S, Shin K-S, Jang H-L, Kim S-Y, Choi Y-K. 2012. Prevalence and genetic characterization of respiratory syncytial virus (RSV) in hospitalized children in Korea. Archives of Virology 157(6):1039-1050.

11. Bielejec F, Rambaut A, Suchard MA, Lemey P. 2011. SPREAD: spatial phylogenetic reconstruction of evolutionary dynamics. Bioinformatics 27(20):2910-2912.

12. Black CP. 2003. Systematic review of the biology and medical management of respiratory syncytial virus infection. Respiratory Care 48(3):209-233.

13. Bloemers BLP, van Furth AM, Weijerman ME, Gemke RJBJ, Broers CJM, van den Ende K, Kimpen JLL, Strengers JLM, Bont LJ. 2007. Down syndrome: a novel risk factor for respiratory syncytial virus bronchiolitis - a prospective birth-cohort study. Pediatrics 120(4):e1076-e1081.

14. Bloom-Feshbach K, Alonso WJ, Charu V, Tamerius J, Simonsen L, Miller MA, Viboud C. 2013. Latitudinal variations in seasonal activity of influenza and respiratory syncytial virus (RSV): a global comparative review. PLoS ONE 8(2):e54445. 
15. Botosso VF, Zanotto PMdA, Ueda M, Arruda E, Gilio AE, Vieira SE, Stewien KE, Peret TCT, Jamal LF, Pardini MIdMC, Pinho JRR, Massad E, Sant'Anna OA, Holmes EC, Durigon EL, and the VC. 2009. Positive selection results in frequent reversible amino acid replacements in the $\mathrm{G}$ protein sene of human respiratory syncytial virus. PLoS Pathog 5(1):e1000254.

16. Bowles NE, Ni J, Kearney DL, Pauschinger M, Schultheiss H-P, McCarthy R, Hare J, Bricker JT, Bowles KR, Towbin JA. 2003. Detection of viruses in myocardial tissues by polymerase chain reaction: evidence of adenovirus as a common cause of myocarditis in children and adults. Journal of the American College of Cardiology 42(3):466-472.

17. Brandenburg AH, Groen J, Steensel-Moll HAv, Claas ECJ, Rothbarth PH, Neijens HJ, Osterhaus ADME. 1997. Respiratory syncytial virus specific serum antibodies in infants under six months of age: limited serological response upon infection. Journal of Medical Virology 52(1):97-104.

18. Cane PA. 1997. Analysis of linear epitopes recognised by the primary human antibody response to a variable region of the attachment $(\mathrm{G})$ protein of respiratory syncytial virus. Journal of Medical Virology 51(4):297-304.

19. Cane PA. 2001. Molecular epidemiology of respiratory syncytial virus. Reviews in Medical Virology 11(2):103-116.

20. Cane PA, Pringle CR. 1995. Evolution of subgroup A respiratory syncytial virus: evidence for progressive accumulation of amino acid changes in the attachment protein. Journal of Virology 69(5):2918-2925.

21. Castro-Nallar E, Pérez-Losada M, Burton GF, Crandall KA. 2012. The evolution of HIV: Inferences using phylogenetics. Molecular Phylogenetics and Evolution 62(2):777-792.

22. Chanock R, Finberg L. 1957. Recovery from infants with respiratory illness of a virus related to chimpanzee coryza agent (CCA): Epidemiologic aspects of infection in infants and young children. American Journal of Epidemiology 66(3):291-300.

23. Chemaly RF, Torres HA, Munsell MF, Shah DP, Rathod DB, Bodey GP, Hosing C, Saifan C, Raad II, Champlin RE. 2012. An adaptive randomized trial of an intermittent dosing schedule of aerosolized ribavirin in patients with cancer and respiratory syncytial virus infection. Journal of Infectious Diseases 206(9):1367-1371.

24. Chowdhury MM, McKenzie SA, Pearson CC, Carr S, Pao C, Shah AR, Reus E, Eliahoo J, Gordon F, Bland H, Habibi P. 2013. Heliox therapy in bronchiolitis: phase III multicenter double-blind randomized controlled trial. Pediatrics 131(4):661-669.

25. Collins P, Crowe J. 2007. Respiratory syncytial virus and metapneumovirus. In: Knipe D, Howley P, editors. Fields virology. 5th ed. Philadelphia: Lippincott Williams \& Wilkins. p 1602-1646.

26. Collins PL, Graham BS. 2008. Viral and host factors in human respiratory syncytial virus pathogenesis. Journal of Virology 82(5):2040-2055.

27. Collins PL, Melero JA. 2011. Progress in understanding and controlling respiratory syncytial virus: Still crazy after all these years. Virus Research 162(1-2):80-99.

28. Connors M, Collins PL, Firestone CY, Murphy BR. 1991. Respiratory syncytial virus (RSV) F, G, M2 (22K), and N proteins each induce resistance to RSV challenge, but resistance induced by $\mathrm{M} 2$ and $\mathrm{N}$ proteins is relatively short-lived. Journal of Virology 65(3):1634-1637. 
29. Cui G, Qian Y, Zhu R, Deng J, Zhao L, Sun Y, Wang F. 2013. Emerging human respiratory syncytial virus genotypeON1 found in infants with pneumonia in Beijing, China. Emerging Microbes and Infections 2(4):e22.

30. Dapat IC, Shobugawa Y, Sano Y, Saito R, Sasaki A, Suzuki Y, Kumaki A, Zaraket H, Dapat C, Oguma T, Yamaguchi M, Suzuki H. 2010. New genotypes within respiratory syncytial virus group B genotype BA in Niigata, Japan. Journal of Clinical Microbiology 48(9):3423-3427.

31. Delport W, Poon AFY, Frost SDW, Kosakovsky Pond SL. 2010. Datamonkey 2010: a suite of phylogenetic analysis tools for evolutionary biology. Bioinformatics 26(19):2455-2457.

32. Drummond A, Pybus O, Rambaut A. 2003. Inference of viral evolutionary rates from molecular sequences. Advances in Parasitology 54:331-358.

33. Drummond AJ, Rambaut A, Shapiro B, Pybus OG. 2005. Bayesian coalescent inference of past population dynamics from molecular sequences. Molecular Biology and Evolution 22(5):1185-1192.

34. Drummond AJ, Suchard MA, Xie D, Rambaut A. 2012. Bayesian phylogenetics with BEAUti and the BEAST 1.7. Molecular Biology and Evolution 29(8):1969-1973.

35. Enriquez A, Chu IW, Mellis C, Lin W-Y. 2012. Nebulised deoxyribonuclease for viral bronchiolitis in children younger than 24 months. Cochrane Database of Systematic Reviews 11:CD008395.

36. Eshaghi A, Duvvuri VR, Lai R, Nadarajah JT, Li A, Patel SN, Low DE, Gubbay JB. 2012. Genetic variability of human respiratory syncytial virus A strains circulating in Ontario: A novel genotype with a 72 nucleotide $G$ gene duplication. PLoS ONE 7(3):e32807.

37. Etemadi M, Sekawi Z, Othman N, Lye M, Moghaddam F. 2013. Circulation of human respiratory syncytial virus strains among hospitalized children with acute lower respiratory infection in Malaysia. Evolutionary Bioinformatics Online 9:151-161

38. Falsey AR, Hennessey PA, Formica MA, Cox C, Walsh EE. 2005. Respiratory syncytial virus infection in elderly and high-risk adults. New England Journal of Medicine 352(17):1749-1759.

39. Falsey AR, Walsh EE. 2000. Respiratory syncytial virus infection in adults. Clinical Microbiology Reviews 13(3):371-384.

40. Feinstein AR. 2002. Principles of medical statistics. London: Chapman \& Hall/CRC. $703 \mathrm{p}$.

41. Feltes TF, Cabalka AK, Meissner HC, Piazza FM, Carlin DA, Top FH, Connor EM, Sondheimer HM, for the Cardiac Synagis Study G. 2003. Palivizumab prophylaxis reduces hospitalization due to respiratory syncytial virus in young children with hemodynamically significant congenital heart disease. The Journal of Pediatrics 143(4):532-540.

42. Fernandes R, Bialy L, Vandermeer B, Tjosvold L, Plint A, Patel H, Johnson D, Klassen T, Hartling L. 2010. Glucocorticoids for acute viral bronchiolitis in infants and young children. The Cochrane Database of Systematic Reviews 6(10):CD004878.

43. Fischer Langley G, McCracken J, Arvelo W, Estevez A, Villarruel G, Prill M, Iwane M, Gray J, Moscoso F, Reyes L, Moir JC, Ortiz J, Lindblade K. 2013. The epidemiology and clinical characteristics of young children hospitalized with respiratory syncytial virus infections in Guatemala (2007-2010). The Pediatric Infectious Disease Journal 32(6):629-635. 
44. Fleming DM, Pannell RS, Elliot AJ, Cross KW. 2005. Respiratory illness associated with influenza and respiratory syncytial virus infection. Archives of Disease in Childhood 90(7):741-746.

45. Frost SDW, Volz EM. 2010. Viral phylodynamics and the search for an 'effective number of infections'. Philosophical Transactions of the Royal Society B: Biological Sciences 365(1548):1879-1890.

46. Gadomski A, Brower M. 2010. Bronchodilators for bronchiolitis. The Cochrane Database of Systematic Reviews 8(12):CD001266

47. García CG, Bhore R, Soriano-Fallas A, Trost M, Chason R, Ramilo O, Mejias A. 2010. Risk factors in children hospitalized with RSV bronchiolitis versus non-RSV bronchiolitis. Pediatrics 126(6):e1453-e1460.

48. Gaunt ER, Jansen RR, Poovorawan Y, Templeton KE, Toms GL, Simmonds P. 2011. Molecular epidemiology and evolution of human respiratory syncytial virus and human metapneumovirus. PLoS ONE 6(3):e17427.

49. Geis S, Prifert C, Weissbrich B, Lehners N, Egerer G, Eisenbach C, Buchholz U, Aichinger E, Dreger P, Neben K, Burkhardt U, Ho AD, Kräusslich H-G, Heeg K, Schnitzler P. 2013. Molecular characterization of a respiratory syncytial virus outbreak in a hematology unit in Heidelberg, Germany. Journal of Clinical Microbiology 51(1):155-162.

50. Gilbert LL, Dakhama A, Bone BM, Thomas EE, Hegele RG. 1996. Diagnosis of viral respiratory tract infections in children by using a reverse transcription-PCR panel. Journal of Clinical Microbiology 34(1):140-143.

51. Glezen W, Taber L, Frank A, Kasel J. 1986. Risk of primary infection and reinfection with respiratory syncytial virus. American Journal of Diseases of Children 140(6):543546.

52. Goldstein B, Giroir B, Randolph A, Sepsis MotICCoP. 2005. International pediatric sepsis consensus conference: Definitions for sepsis and organ dysfunction in pediatrics. Pediatric Critical Care Medicine 6(1):2-8.

53. Guerguerian A-M, Gauthier M, Lebel M, Farrell C, Lacroix J. 1999. Ribavirin in ventilated respiratory syncytial virus bronchiolitis. American Journal of Respiratory and Critical Care Medicine 160(3):829-834.

54. Gupta R, Jung E, Brunak S. 2004. Prediction of N-glycosylation sites in human proteins. http://www.cbs.dtu.dk/services/NetNGlyc/.

55. Hall CB. 2000. Nosocomial respiratory syncytial virus infections: the "Cold War" has not ended. Clinical Infectious Diseases 31(2):590-596.

56. Hall CB, Walsh EE, Schnabel KC, Long CE, McConnochie KM, Hildreth SW, Anderson LJ. 1990. Occurrence of groups A and B of respiratory syncytial virus over 15 years: associated epidemiologic and clinical characteristics in hospitalized and ambulatory children. Journal of Infectious Diseases 162(6):1283-1290.

57. Hall CB, Weinberg GA, Iwane MK, Blumkin AK, Edwards KM, Staat MA, Auinger P, Griffin MR, Poehling KA, Erdman D, Grijalva CG, Zhu Y, Szilagyi P. 2009. The burden of respiratory syncytial virus Infection in young children. New England Journal of Medicine 360(6):588-598.

58. Hall TA. 1999. BioEdit: a user-friendly biological sequence alignment editor and analysis program for Windows 95/98/NT. Nucleic Acids Symposium Series 41:95-98.

59. Hancock GE, Tebbey PW, Scheuer CA, Pryharski KS, Heers KM, LaPierre NA. 2003. Immune responses to the nonglycosylated ectodomain of respiratory syncytial virus 
attachment glycoprotein mediate pulmonary eosinophilia in inbred strains of mice with different MHC haplotypes. Journal of Medical Virology 70(2):301-308.

60. Hart GW. 1992. Glycosylation. Current Opinion in Cell Biology 4(6):1017-1023.

61. Hartling L, Fernandes RM, Bialy L, Milne A, Johnson D, Plint A, Klassen TP, Vandermeer B. 2011. Steroids and bronchodilators for acute bronchiolitis in the first two years of life: systematic review and meta-analysis. BMJ 342.

62. Hasegawa M, Kishino H, Yano T. 1985. Dating of the human-ape splitting by a molecular clock of mitochondrial DNA. Journal of Molecular Evolution 22(2):160174.

63. Heikkinen T, Ruuskanen O. 1995. Signs and symptoms predicting acute otitis media. Archives of Pediatrics \& Adolescent Medicine 149(1):26-29.

64. Heikkinen T, Thint M, Chonmaitree T. 1999. Prevalence of various respiratory viruses in the middle ear during acute otitis media. New England Journal of Medicine 340(4):260-264.

65. Henderson FW, Collier AM, Clyde WA, Denny FW. 1979. Respiratory-syncytial-virus infections, reinfections and immunity. New England Journal of Medicine 300(10):530534.

66. Henrickson KJ, Hall CB. 2007. Diagnostic assays for respiratory syncytial virus disease. The Pediatric Infectious Disease Journal 26(11):S36-S40.

67. Henrickson KJ, Hoover S, Kehl KS, Hua W. 2004. National disease burden of respiratory viruses detected in children by polymerase chain reaction. The Pediatric Infectious Disease Journal 23(1):S11-S18.

68. Holberg CJ, Wright AL, Martinez FD, Ray CG, Taussing LM, Lebowitz MD. 1991. Risk factors for respiratory syncytial virus-associated lower respiratory illnesses in the first year of life. American Journal of Epidemiology 133(11):1135-1151.

69. Holmes E. 2008. Evolutionary history and phylogeography of human viruses. Annual Review of Microbiology 62:307-328.

70. Hornsleth A, Klug B, Nir M, Johansen J, Hansen K, Christensen L, Larsen LB. 1998. Severity of respiratory syncytial virus disease related to type and genotype of virus and to cytokine values in nasopharyngeal secretions. The Pediatric Infectious Disease Journal 17(12):1114-1121.

71. Houspie L, Lemey P, Keyaerts E, Reijmen E, Vergote V, Vankeerberghen A, Vaeyens F, De Beenhouwer H, van Ranst M. 2013. Circulation of HRSV in Belgium: from multiple genotype circulation to prolonged circulation of predominant genotypes. PLoS ONE 8(4):e60416.

72. Imaz MS, Sequeira MD, Videla C, Veronessi I, Cociglio R, Zerbini E, Carballal G. 2000. Clinical and epidemiologic characteristics of respiratory syncytial virus subgroups A and B infections in Santa Fe, Argentina. Journal of Medical Virology 61(1):76-80.

73. Jafri HS, Wu X, Makari D, Henrickson KJ. 2013. Distribution of respiratory syncytial virus subtypes $\mathrm{A}$ and $\mathrm{B}$ among infants presenting to the emergency department with lower respiratory tract Infection or apnea. The Pediatric Infectious Disease Journal 32(4):335-340.

74. Jartti T, Söderlund-Venermo M, Hedman K, Ruuskanen O, Mäkelä MJ. 2013. New molecular virus detection methods and their clinical value in lower respiratory tract infections in children. Paediatric respiratory reviews 14(1):38-45. 
75. Jat KR, Chawla D. 2012. Surfactant therapy for bronchiolitis in critically ill infants. Cochrane Database of Systematic Reviews 9:CD009194

76. Johnson JE, Gonzales RA, Olson SJ, Wright PF, Graham BS. 2007. The histopathology of fatal untreated human respiratory syncytial virus infection. Modern Patholology 20(1):108-119.

77. Johnson LW, Robles J, Hudgins A, Osburn S, Martin D, Thompson A. 2013. Management of bronchiolitis in the emergency department: impact of evidence-based guidelines? Pediatrics 131(Supplement 1):S103-S109.

78. Johnson PR, Spriggs MK, Olmsted RA, Collins PL. 1987. The G glycoprotein of human respiratory syncytial viruses of subgroups A and B: extensive sequence divergence between antigenically related proteins. Proceedings of the National Academy of Sciences 84(16):5625-5629.

79. Johnson S, Oliver C, Prince G, Hemming V, Pfarr D, Wang S, Dormitzer M, O'Grady J, Koenig S, Tamura J, Woods R, Bansal G, Couchenour D, Tsao E, Hall W, Young J. 1997. Development of a humanized monoclonal antibody (MEDI-493) with potent in vitro and in vivo activity against respiratory syncytial virus. The Journal of Infectious Diseases 176(5):1215-1224.

80. Julenius K, Mølgaard A, Gupta R, Brunak S. 2005. Prediction, conservation analysis, and structural characterization of mammalian mucin-type O-glycosylation sites. Glycobiology 15(2):153-164.

81. Karron RA, Buonagurio DA, Georgiu AF, Whitehead SS, Adamus JE, Clements-Mann ML, Harris DO, Randolph VB, Udem SA, Murphy BR, Sidhu MS. 1997. Respiratory syncytial virus (RSV) SH and G proteins are not essential for viral replication in vitro: Clinical evaluation and molecular characterization of a cold-passaged, attenuated RSV subgroup B mutant. Proceedings of the National Academy of Sciences 94(25):1396113966.

82. Katzov-Eckert H, Botosso V, Neto E, Zanotto P, VGND consortium. 2012. Phylodynamics and dispersal of HRSV entails its permanence in the general population in between yearly outbreaks in children. PLoS One 7(10):e41953.

83. Khor C-S, Sam IC, Hooi P-S, Chan Y-F. 2013. Displacement of predominant respiratory syncytial virus genotypes in Malaysia between 1989 and 2011. Infection, Genetics and Evolution 14(0):357-360.

84. Kneyber M, Brandenburg A, Rothbarth P, de Groot R, Ott A, van Steensel-Moll H. 1996. Relationship between clinical severity of respiratory syncytial virus infection and subtype. Archives of Disease in Childhood 75(2):137-140.

85. Kneyber MCJ, van Woensel JBM, Uijtendaal E, Uiterwaal CSPM, Kimpen JLL. 2008. Azithromycin does not improve disease course in hospitalized infants with respiratory syncytial virus (RSV) lower respiratory tract disease: A randomized equivalence trial. Pediatric Pulmonology 43(2):142-149.

86. Kosakovsky Pond SL, Frost SDW. 2005. Not so different after all: a comparison of methods for detecting amino acid sites under selection. Molecular Biology and Evolution 22(5):1208-1222.

87. Kosakovsky Pond SL, Frost SDW, Grossman Z, Gravenor MB, Richman DD, Brown AJL. 2006. Adaptation to different human populations by HIV-1 revealed by codonbased analyses. PLoS Computational Biology 2(6):e62.

88. Kosakovsky Pond SL, Frost SDW, Muse SV. 2005. HyPhy: hypothesis testing using phylogenies. Bioinformatics 21(5):676-679. 
89. Krilov LR. 2011. Respiratory syncytial virus disease: update on treatment and prevention. Expert Review of Anti-infective Therapy 9(1):27-32.

90. Kushibuchi I, Kobayashi M, Kusaka T, Tsukagoshi H, Ryo A, Yoshida A, Ishii H, Saraya T, Kurai D, Yamamoto N, Kanou K, Saitoh M, Noda M, Kuroda M, Morita Y, Kozawa K, Oishi K, Tashiro M, Kimura H. 2013. Molecular evolution of attachment glycoprotein $(\mathrm{G})$ gene in human respiratory syncytial virus detected in Japan 20082011. Infection, Genetics and Evolution 18(0):168-173.

91. Lagos R, DeVincenzo JP, Muñoz A, Hultquist M, Suzich J, Connor EM, Losonsky GA. 2009. Safety and antiviral activity of motavizumab, a respiratory syncytial virus (RSV)-specific humanized monoclonal antibody, when administered to RSV-infected children. The Pediatric Infectious Disease Journal 28(9):835-837.

92. Lam TT, Hon CC, Tang JW. 2010. Use of phylogenetics in the molecular epidemiology and evolutionary studies of viral infections. Critical Reviews in Clinical Laboratory Science 47(1):5-49.

93. Langley J, Smith M, LeBlanc J, Joudrey H, Ojah C, Pianosi P. 2005. Racemic epinephrine compared to salbutamol in hospitalized young children with bronchiolitis; a randomized controlled clinical trial [ISRCTN46561076]. BMC Pediatrics 5(1):1-7.

94. Langley JM, LeBlanc JC, Wang EEL, Law BJ, MacDonald NE, Mitchell I, Stephens D, McDonald J, Boucher FD, Dobson S. 1997. Nosocomial respiratory syncytial virus infection in Canadian pediatric hospitals: A Pediatric Investigators Collaborative Network on Infections in Canada study. Pediatrics 100(6):943-946.

95. Larkin MA, Blackshields G, Brown NP, Chenna R, McGettigan PA, McWilliam H, Valentin F, Wallace IM, Wilm A, Lopez R, Thompson JD, Gibson TJ, Higgins DG. 2007. Clustal W and Clustal X version 2.0. Bioinformatics 23(21):2947-2948.

96. Leader S, Kohlhase K. 2003. Recent trends in severe respiratory syncytial virus (RSV) among US infants, 1997 to 2000. The Journal of Pediatrics 143(5):127-132.

97. Lee W-J, Kim Y-j, Kim D-W, Lee HS, Lee HY, Kim K. 2012. Complete genome sequence of human respiratory syncytial virus genotype A with a 72-nucleotide duplication in the attachment protein G gene. Journal of Virology 86(24):13810-13811.

98. Lemey P, Rambaut A, Drummond A, Suchard MA. 2009. Bayesian phylogeography finds its roots. PLos Computational Biology 5(9):e1000520.

99. Librado P, Rozas J. 2009. DnaSP v5: a software for comprehensive analysis of DNA polymorphism data. Bioinformatics 25(11):1451-1452.

100.Liljeroos L, Krzyzaniak MA, Helenius A, Butcher SJ. 2013. Architecture of respiratory syncytial virus revealed by electron cryotomography. Proceedings of the National Academy of Sciences 110(27):11133-11138.

101.Liolios L, Jenney A, Spelman D, Kotsimbos T, Catton M, Wesselingh S. 2001. Comparison of a multiplex reverse transcription-PCR-enzyme hybridization assay with conventional viral culture and immunofluorescence techniques for the detection of seven viral respiratory pathogens. Journal of Clinical Microbiology 39(8):2779-2783.

102.Lowell DI, Lister G, Von Koss H, McCarthy P. 1987. Wheezing in infants: the response to epinephrine. Pediatrics 79(6):939-945.

103.Lozano R, Naghavi M, Foreman K, Lim S, Shibuya K, Aboyans V, Abraham J, Adair T, Aggarwal R, Ahn SY, AlMazroa MA, Alvarado M, Anderson HR, Anderson LM, Andrews KG, Atkinson C, Baddour LM, Barker-Collo S, Bartels DH, Bell ML, Benjamin EJ, Bennett D, Bhalla K, Bikbov B, Abdulhak AB, Birbeck G, Blyth F, Bolliger I, Boufous S, Bucello C, Burch M, Burney P, Carapetis J, Chen H, Chou D, 
Chugh SS, Coffeng LE, Colan SD, Colquhoun S, Colson KE, Condon J, Connor MD, Cooper LT, Corriere M, Cortinovis M, de Vaccaro KC, Couser W, Cowie BC, Criqui MH, Cross M, Dabhadkar KC, Dahodwala N, De Leo D, Degenhardt L, Delossantos A, Denenberg J, Des Jarlais DC, Dharmaratne SD, Dorsey ER, Driscoll T, Duber H, Ebel B, Erwin PJ, Espindola P, Ezzati M, Feigin V, Flaxman AD, Forouzanfar MH, Fowkes FGR, Franklin R, Fransen M, Freeman MK, Gabriel SE, Gakidou E, Gaspari F, Gillum RF, Gonzalez-Medina D, Halasa YA, Haring D, Harrison JE, Havmoeller R, Hay RJ, Hoen B, Hotez PJ, Hoy D, Jacobsen KH, James SL, Jasrasaria R, Jayaraman S, Johns N, Karthikeyan G, Kassebaum N, Keren A, Khoo J-P, Knowlton LM, Kobusingye O, Koranteng A, Krishnamurthi R, Lipnick M, Lipshultz SE, Ohno SL, Mabweijano J, MacIntyre MF, Mallinger L, March L, Marks GB, Marks R, Matsumori A, Matzopoulos R, Mayosi BM, McAnulty JH, McDermott MM, McGrath J, Memish ZA, Mensah GA, Merriman TR, Michaud C, Miller M, Miller TR, Mock C, Mocumbi AO, Mokdad AA, Moran A, Mulholland K, Nair MN, Naldi L, Narayan KMV, Nasseri K, Norman P, O'Donnell M, Omer SB, Ortblad K, Osborne R, Ozgediz D, Pahari B, Pandian JD, Rivero AP, Padilla RP, Perez-Ruiz F, Perico N, Phillips D, Pierce K, Pope Iii CA, Porrini E, Pourmalek F, Raju M, Ranganathan D, Rehm JT, Rein DB, Remuzzi G, Rivara FP, Roberts T, De León FR, Rosenfeld LC, Rushton L, Sacco RL, Salomon JA, Sampson U, Sanman E, Schwebel DC, Segui-Gomez M, Shepard DS, Singh D, Singleton J, Sliwa K, Smith E, Steer A, Taylor JA, Thomas B, Tleyjeh IM, Towbin JA, Truelsen T, Undurraga EA, Venketasubramanian N, Vijayakumar L, Vos T, Wagner GR, Wang M, Wang W, Watt K, Weinstock MA, Weintraub R, Wilkinson JD, Woolf AD, Wulf S, Yeh P-H, Yip P, Zabetian A, Zheng Z-J, Lopez AD, Murray CJL. 2012. Global and regional mortality from 235 causes of death for 20 age groups in 1990 and 2010: a systematic analysis for the Global Burden of Disease Study 2010. The Lancet 380(9859):2095-2128.

104.Macfarlane P, Denham J, Assous J, Hughes C. 2005. RSV testing in bronchiolitis: which nasal sampling method is best? Archives of Disease in Childhood 90(6):634635.

105.Mahony JB. 2008. Detection of respiratory viruses by molecular methods. Clinical Microbiology Reviews 21(4):716-747.

106.Malley R, DeVincenzo J, Ramilo O, Dennehy PH, Meissner HC, Gruber WC, Sanchez PJ, Jafri H, Balsley J, Carlin D, Buckingham S, Vernacchio L, Ambrosino DM. 1998. Reduction of respiratory syncytial virus (RSV) in tracheal aspirates in intubated infants by use of humanized monoclonal antibody to RSV F protein. Journal of Infectious Diseases 178(6):1555-1561.

107.Martinello RA, Chen MD, Weibel C, Kahn JS. 2002. Correlation between respiratory syncytial virus genotype and severity of illness. Journal of Infectious Diseases 186(6):839-842.

108.Martinez I, Dopazo J, Melero JA. 1997. Antigenic structure of the human respiratory syncytial virus $G$ glycoprotein and relevance of hypermutation events for the generation of antigenic variants. Journal of General Virology 78(10):2419-2429.

109.McIntosh E, De Silva L, Oates R. 1993. Clinical severity of respiratory syncytial virus group $\mathrm{A}$ and $\mathrm{B}$ infection in Sydney, Australia. Pediatric Infectious Disease Journal 12(10):815-819. 
110.Meijboom MJ, Rozenbaum MH, Benedictus A, Luytjes W, Kneyber MCJ, Wilschut JC, Hak E, Postma MJ. 2012. Cost-effectiveness of potential infant vaccination against respiratory syncytial virus infection in The Netherlands. Vaccine 30(31):4691-4700.

111. Melero JA. 2007. Molecular biology of human respiratory syncytial virus. In: Cane PA, editor. Respiratory syncytial virus. 1st ed. Amsterdam: Elsevier. p 1-42.

112.Mizuta K, Saitoh M, Kobayashi M, Tsukagoshi H, Aoki Y, Ikeda T, Abiko C, Katsushima N, Itagaki T, Noda M, Kozawa K, Ahiko T, Kimura H. 2011. Detailed genetic analysis of hemagglutinin-neuraminidase glycoprotein gene in human parainfluenza virus type 1 isolates from patients with acute respiratory infection between 2002 and 2009 in Yamagata prefecture, Japan. Virology Journal 8(1):533.

113.Mlinaric-Galinovic G, Tabain I, Kukovec T, Vojnovic G, Bozikov J, Bogovic-Cepin J, Ivkovic-Jurekovic I, Knezovic I, Tesovic G, Welliver RC. 2012. Analysis of biennial outbreak pattern of respiratory syncytial virus according to subtype (A and B) in the Zagreb region. Pediatrics International 54(3):331-335.

114.Morris JA, Blount RE, Savage RE. 1956. Recovery of cytopathogenic agent from chimpanzees with coryza. Experimental Biology and Medicine 92(3):544-549.

115.Mufson MA, Örvell C, Rafnar B, Norrby E. 1985. Two distinct subtypes of human respiratory syncytial virus. Journal of General Virology 66(10):2111-2124.

116.Mullins JA, Lamonte AC, Bresee JS, Anderson LJ. 2003. Substantial variability in community respiratory syncytial virus season timing. The Pediatric Infectious Disease Journal 22(10):857-863.

117.Murrell B, Wertheim JO, Moola S, Weighill T, Scheffler K, Kosakovsky Pond SL. 2012. Detecting individual sites subject to episodic diversifying selection. PLoS Genetics 8(7):e1002764.

118.Nadal D, Wunderli W, Meurmann O, Briner J, Hirsig J. 1990. Isolation of respiratory syncytial virus from liver tissue and extrahepatic biliary atresia material. Scandinavian Journal of Infectious Diseases 22(1):91-93.

119.Nair H, Nokes DJ, Gessner BD, Dherani M, Madhi SA, Singleton RJ, O'Brien KL, Roca A, Wright PF, Bruce N, Chandran A, Theodoratou E, Sutanto A, Sedyaningsih ER, Ngama M, Munywoki PK, Kartasasmita C, Simões EAF, Rudan I, Weber MW, Campbell H. 2010. Global burden of acute lower respiratory infections due to respiratory syncytial virus in young children: a systematic review and meta-analysis. The Lancet 375(9725):1545-1555.

120.Nair H, Simões EAF, Rudan I, Gessner BD, Azziz-Baumgartner E, Zhang JSF, Feikin DR, Mackenzie GA, Moiïsi JC, Roca A, Baggett HC, Zaman SMA, Singleton RJ, Lucero MG, Chandran A, Gentile A, Cohen C, Krishnan A, Bhutta ZA, Arguedas A, Clara AW, Andrade AL, Ope M, Ruvinsky RO, Hortal M, McCracken JP, Madhi SA, Bruce N, Qazi SA, Morris SS, El Arifeen S, Weber MW, Scott JAG, Brooks WA, Breiman RF, Campbell H. 2013. Global and regional burden of hospital admissions for severe acute lower respiratory infections in young children in 2010: a systematic analysis. The Lancet 381(9875):1380-1390.

121.Nielsen HE, Siersma V, Andersen S, Gahrn-Hansen B, Mordhorst CH, NørgaardPedersen B, Røder B, Sørensen TL, Temme R, Vestergaard BF. 2003. Respiratory syncytial virus infection-risk factors for hospital admission: a case-control study. Acta Paediatrica 92(11):1314-1321. 
122.Nikiforova R, Kantsone I. 2011. Pārskats par akūtu augšējo elpcel̦u infekciju (AAEI) un gripas izplatību 2011. gada 20.nedēl̦ā Latvijā. Epidemioloǵijas biḷ̂tens 28(1199):18.

123.Nikiforova R, Lucenko I, Zamjatina N. 2011. Pārskats par saslimstību ar akūtām augšējo elpceḷu infekcijām (AAEI) un gripu 2010. - 2011. gada epidēmiskajā sezonā. Epidemiologijas biļetens 34(1205):1-21.

124.Nikiforova R, Perevoščikovs J, Lucenko I. 2010. Pārskats par saslimstību ar akūtām augšējo elpcelı infekcijām (AAEI) un gripu 2009. - 2010. gada epidēmiskajā sezonā. Epidemiologiijas bil̦etens 31(1152):1-22.

125.Nikiforova R, Pulmane K. 2012. Pārskats par akūtu augšējo elpcel̦u infekciju (AAEI) un gripas izplatību 2012. gada 20.nedēḷā Latvijā. Epidemiolog̣ijas biḷetens 29(1251):111.

126.Nikiforova R, Pulmane K. 2013. Pārskats par akūto augšējo elpceļu infekciju (AAEI) un gripas izplatību 2013. gada 20.nedēḷā Latvijā. Epidemiologijas biḷetens 30(1301):111.

127.Norrby E, Mufson MA, Alexander H, Houghten RA, Lerner RA. 1987. Site-directed serology with synthetic peptides representing the large glycoprotein $\mathrm{G}$ of respiratory syncytial virus. Proceedings of the National Academy of Sciences 84(18):6572-6576.

128.O'Donnell DR, McGarvey MJ, Tully JM, Balfour-Lynn IM, Openshaw PJM. 1998. Respiratory syncytial virus RNA in cells from the peripheral blood during acute infection. The Journal of Pediatrics 133(2):272-274.

129. Ohno A, Suzuki A, Lupisan S, Galang H, Sombrero L, Aniceto R, Okamoto M, Saito M, Fuji N, Otomaru H, Roy CN, Yamamoto D, Tamaki R, Olveda R, Oshitani H. 2013. Genetic characterization of human respiratory syncytial virus detected in hospitalized children in the Philippines from 2008 to 2012. Journal of Clinical Virology 57(1):59-65.

130.Palomo C, García-Barreno B, Peñas C, Melero JA. 1991. The G protein of human respiratory syncytial virus: significance of carbohydrate side-chains and the $\mathrm{C}$-terminal end to its antigenicity. Journal of General Virology 72(3):669-675.

131.Panozzo CA, Stockman LJ, Curns AT, Anderson LJ. 2010. Use of respiratory syncytial virus surveillance data to optimize the timing of immunoprophylaxis. Pediatrics 126(1):e116-e123.

132.Patel H, Platt RW, Pekeles GS, Ducharme FM. 2002. A randomized, controlled trial of the effectiveness of nebulized therapy with epinephrine compared with albuterol and saline in infants hospitalized for acute viral bronchiolitis. The Journal of Pediatrics 141(6):818-824.

133.Pavia AT. 2011. Viral Infections of the lower respiratory tract: old viruses, new viruses, and the role of diagnosis. Clinical Infectious Diseases 52(Supplement 4):S284S289.

134.Pelletier AJ, Mansbach JM, Camargo CA. 2006. Direct medical costs of bronchiolitis hospitalizations in the United States. Pediatrics 118(6):2418-2423.

135.Peret TC, Hall CB, Schnabel KC, Golub JA, Anderson LJ. 1998. Circulation patterns of genetically distinct group A and B strains of human respiratory syncytial virus in a community. Journal of General Virology 79(9):2221-2229.

136.Peret TCT, Hall CB, Hammond GW, Piedra PA, Storch GA, Sullender WM, Tsou C, Anderson LJ. 2000. Circulation patterns of group A and B human respiratory syncytial 
virus genotypes in 5 communities in North America. Journal of Infectious Diseases 181(6):1891-1896.

137.Perevoščikovs J, Lucenko I. 2010. Imunizācijas Valsts padomes sēdes protokols. Rīga: Imunizācijas Valsts padome. 1-9 p.

138.Peters TR, Crowe JE. 2008. Respiratory syncytial virus. In: Long SS, Pickering LK, Prober $\mathrm{CG}$, editors. Principles and practice of pediatric infectious diseases. 3rd ed. Phildelphia: Churchill Livingstone. p 1112-1116.

139.Pinto LA, Pitrez PM, Luisi F, de Mello PP, Gerhardt M, Ferlini R, Barbosa DC, Daros I, Jones MH, Stein RT, Marostica PJ. 2012. Azithromycin therapy in hospitalized infants with acute bronchiolitis is not associated with better clinical outcomes: a randomized, double-blinded, and placebo-controlled clinical trial. The Journal of Pediatrics 161(6):1104-1108.

140.Pipavath S, Lynch D, Cool C, Brown K, Newell J. 2005. Radiologic and pathologic features of bronchiolitis. American Journal of Roentgenology 185(2):354-363.

141.Prifert C, Streng A, Krempl C, Liese J, Weissbrich B. 2013. Novel respiratory syncytial virus a genotype, Germany, 2011-2012. Emerging Infectious Diseases 19(6):1029-1030.

142.Qin X, Zhang C, Zhao Y, Zhao X. 2013. Genetic variability of subgroup A and B respiratory syncytial virus strains circulating in southwestern China from 2009 to 2011. Archives of Virology 158(7):1487-1495.

143.Rafiefard F, Örvell C, Bondeson K. 2008. Genotyping of respiratory syncytial virus (RSV) group A in Stockholm, Sweden, using PCR and two-dimensional melting curve analysis. APMIS 116(4):317-322.

144.Rebuffo-Scheer C, Bose M, He J, Khaja S, Ulatowski M, Beck E, Fan J, Kumar S, Nelson M, Henrickson K. 2011. Whole genome sequencing and evolutionary analysis of human respiratory syncytial virus A and B from Milwaukee, WI 1998-2010. PLoS ONE 6(10):e25468.

145.Reiche J, Schweiger B. 2009. Genetic variability of group A human respiratory syncytial virus strains circulating in Germany from 1998 to 2007. Journal of Clinical Microbiology 47(6):1800-1810.

146.Resch B, Gusenleitner W, Müller W. 2002. The impact of respiratory syncytial virus infection: a prospective study in hospitalized infants younger than 2 years. Infection 30(4):193-197.

147.Resch B, Manzoni P, Lanari M. 2009. Severe respiratory syncytial virus (RSV) infection in infants with neuromuscular diseases and immune deficiency syndromes. Paediatric Respiratory Reviews 10(3):148-153.

148.Reyes M, Eriksson M, Bennet R, Hedlund K, Ehrnst A. 1997. Regular pattern of respiratory syncytial virus and rotavirus infections and relation to weather in Stockholm, 1984--1993. Clinical Microbiology and Infection 3(6):640-646.

149.Reynolds EOR, Cook CD. 1963. The treatment of bronchiolitis. The Journal of pediatrics 63(6):1205-1207.

150.Roberts SR, Lichtenstein D, Ball LA, Wertz GW. 1994. The membrane-associated and secreted forms of the respiratory syncytial virus attachment glycoprotein $G$ are synthesized from alternative initiation codons. Journal of Virology 68(7):4538-4546.

151.Rojas M, Granados Rugeles C, Charry-Anzola L. 2009. Oxygen therapy for lower respiratory tract infections in children between 3 months and 15 years of age. The Cochrane Database of Systematic Reviews 21(1):CD005975. 
152.Root ED, Gaensbauer J, Nohynek H, Lucero M, Tanskanen A, Nillos L, Tallo V, Simeõs EAF. 2012. Evolution of respiratory syncytial virus (RSV) over space and time in rural Filipino children. Proceedings of the First ACM SIGSPATIAL International Workshop on Use of GIS in Public Health. Redondo Beach, California: ACM. p 57-62.

153.Roqué i Figuls M, Giné-Garriga M, Granados Rugeles C, Perrotta C. 2012. Chest physiotherapy for acute bronchiolitis in paediatric patients between 0 and 24 months old. Cochrane Database of Systematic Reviews 2:CD004873.

154.Roth DE, Caulfield LE, Ezzati M, Black RE. 2008. Acute lower respiratory infections in childhood: opportunities for reducing the global burden through nutritional interventions. Bulletin of the World Health Organization 86(5):356-364.

155.Rudan I, Boschi-Pinto C, Biloglav Z, Mulholland K, Campbell H. 2008. Epidemiology and etiology of childhood pneumonia. Bulletin of the World Health Organization 86(5):408-416.

156.Rueda P, Delgado T, Portela A, Melero JA, García-Barreno B. 1991. Premature stop codons in the $\mathrm{G}$ glycoprotein of human respiratory syncytial viruses resistant to neutralization by monoclonal antibodies. Journal of Virology 65(6):3374-3378.

157.Ruuskanen O, Lahti E, Jennings LC, Murdoch DR. 2011. Viral pneumonia. The Lancet 377(9773):1264-1275.

158.Saitoh M, Takeda M, Gotoh K, Takeuchi F, Sekizuka T, Kuroda M, Mizuta K, Ryo A, Tanaka R, Ishii H, Takada H, Kozawa K, Yoshida A, Noda M, Okabe N, Kimura H. 2012. Molecular evolution of hemagglutinin $(\mathrm{H})$ gene in measles virus genotypes D3, D5, D9, and H1. PLoS ONE 7(11):e50660.

159.Saitou N, Nei M. 1987. The neighbor-joining method: a new method for reconstructing phylogenetic trees. Molecular Biology and Evolution 4(4):406-425.

160.Sande CJ, Mutunga MN, Medley GF, Cane PA, Nokes DJ. 2013. Group- and genotype-specific neutralizing antibody responses against respiratory syncytial virus in infants and young children with severe pneumonia. Journal of Infectious Diseases 207(3):489-492.

161. Scott PD, Ochola R, Ngama M, Okiro EA, James Nokes D, Medley GF, Cane PA. 2006. Molecular analysis of respiratory syncytial virus reinfections in infants from coastal Kenya. Journal of Infectious Diseases 193(1):59-67.

162.Scottish Intercollegiate Guidelines Network. 2006. Bronchiolitis in children. A national clinical guideline. Edinburgh: Scottish Intercollegiate Guidelines Network. 1$41 \mathrm{p}$.

163. Shaw K, Bell L, Sherman N. 1991. Outpatient assessment of infants with bronchiolitis. American Journal of Diseases of Children 145(2):151-155.

164.Shay DK, Holman RC, Newman RD, Liu LL, Stout JW, Anderson LJ. 1999. Bronchiolitis-associated hospitalizations among us children, 1980-1996. JAMA 282(15):1440-1446.

165. Shay DK, Holman RC, Roosevelt GE, Clarke MJ, Anderson LJ. 2001. Bronchiolitisassociated mortality and estimates of respiratory syncytial virus-associated deaths among US Children, 1979-1997. Journal of Infectious Diseases 183(1):16-22.

166. Shobugawa Y, Saito R, Sano Y, Zaraket H, Suzuki Y, Kumaki A, Dapat I, Oguma T, Yamaguchi M, Suzuki H. 2009. Emerging genotypes of human respiratory syncytial virus subgroup A among patients in Japan. Journal of Clinical Microbiology 47(8):2475-2482. 
167.Simmonds P, Smith DB. 1999. Structural constraints on RNA virus evolution. Journal of Virology 73(7):5787-5794.

168.Simões EAF. 1999. Respiratory syncytial virus infection. The Lancet 354(9181):847.

169.Simões EAF. 2003. Environmental and demographic risk factors for respiratory syncytial virus lower respiratory tract disease. The Journal of Pediatrics 143(5):118126.

170.Simões EAF, Carbonell-Estrany X. 2003. Impact of severe disease caused by respiratory syncytial virus in children living in developed countries. The Pediatric Infectious Disease Journal 22(2):S13-S20.

171.Skjerven HO, Hunderi JOG, Brügmann-Pieper SK, Brun AC, Engen H, Eskedal L, Haavaldsen M, Kvenshagen B, Lunde J, Rolfsjord LB, Siva C, Vikin T, Mowinckel P, Carlsen K-H, Lødrup Carlsen KC. 2013. Racemic adrenaline and inhalation strategies in acute bronchiolitis. New England Journal of Medicine 368(24):2286-2293.

172.Smith DW, Frankel LR, Mathers LH, Tang ATS, Ariagno RL, Prober CG. 1991. A controlled trial of aerosolized ribavirin in infants receiving mechanical ventilation for severe respiratory syncytial virus infection. New England Journal of Medicine 325(1):24-29.

173.Sommer C, Resch B, Simões EAF. 2011. Risk factors for severe respiratory syncytial virus lower respiratory tract infection. The Open Microbiology Journal 5:144-154.

174.Spurling G, Doust J, Del Mar C, Eriksson L. 2011. Antibiotics for bronchiolitis in children. The Cochrane Database of Systematic Reviews 15(6):CD005189.

175.Stensballe L, Devasundaram J, Simões E. 2003. Respiratory syncytial virus epidemics: the ups and downs of a seasonal virus. The Pediatric Infectious Disease Journal 22(2):S21-S32.

176.Sullender WM. 2000. Respiratory syncytial virus genetic and antigenic diversity. Clinical Microbiology Reviews 13(1):1-15.

177.Sullender WM, Sun L, Anderson LJ. 1993. Analysis of respiratory syncytial virus genetic variability with amplified cDNAs. Journal of Clinical Microbiology 31(5):1224-1231.

178.Tamura K, Nei M. 1993. Estimation of the number of nucleotide substitutions in the control region of mitochondrial DNA in humans and chimpanzees. Molecular Biology and Evolution 10(3):512-526.

179.Tamura K, Peterson D, Peterson N, Stecher G, Nei M, Kumar S. 2011. MEGA5: molecular evolutionary genetics analysis using maximum likelihood, evolutionary distance, and maximum parsimony methods. Molecular Biology and Evolution 28(10):2731-2739.

180.Tan L, Lemey P, Houspie L, Viveen MC, Jansen NJG, van Loon AM, Wiertz E, van Bleek GM, Martin DP, Coenjaerts FE. 2012. Genetic variability among complete human respiratory syncytial virus subgroup A genomes: bridging molecular evolutionary dynamics and epidemiology. PLoS ONE 7(12):e51439.

181.Tatochenko V, Uchaikin V, Gorelov A, Gudkov K, Campbell A, Schulz G, Prahl R, Notario G. 2010. Epidemiology of respiratory syncytial virus in children $\leq 2$ years of age hospitalized with lower respiratory tract infections in the Russian Federation: a prospective, multicenter study. Clinical Epidemiology(2):221-227.

182. Tawar RG, Duquerroy S, Vonrhein C, Varela PF, Damier-Piolle L, Castagné N, MacLellan K, Bedouelle H, Bricogne G, Bhella D, Eléouët J-F, Rey FA. 2009. Crystal 
structure of a nucleocapsid-like nucleoprotein-RNA complex of respiratory syncytial virus. Science 326(5957):1279-1283.

183.Terletskaia-Ladwig E, Enders G, Schalasta G, Enders M. 2005. Defining the timing of respiratory syncytial virus (RSV) outbreaks: an epidemiological study. BMC Infectious Diseases 5(1):1-7.

184. The IMpact-RSV Study Group. 1998. Palivizumab, a humanized respiratory syncytial virus monoclonal antibody, reduces hospitalization from respiratory syncytial virus infection in high-risk infants. Pediatrics 102(3):531-537

185.Thompson WW, Shay DK, Weintraub E, et al. 2003. Mortality associated with influenza and respiratory syncytial virus in the united states. JAMA 289(2):179-186.

186.Tran DN, Pham TMH, Ha MT, Tran TTL, Dang TKH, Yoshida L-M, Okitsu S, Hayakawa S, Mizuguchi M, Ushijima H. 2013. Molecular epidemiology and disease severity of human respiratory syncytial virus in Vietnam. PLoS ONE 8(1):e45436.

187. Trento A, Casas I, Calderón A, Garcia-Garcia ML, Calvo C, Perez-Breña P, Melero JA. 2010. Ten years of global evolution of the human respiratory syncytial virus BA genotype with a 60-nucleotide duplication in the G protein gene. Journal of Virology 84(15):7500-7512.

188. Trento A, Galiano M, Videla C, Carballal G, García-Barreno B, Melero JA, Palomo C. 2003. Major changes in the $G$ protein of human respiratory syncytial virus isolates introduced by a duplication of 60 nucleotides. Journal of General Virology 84(11):3115-3120.

189.Trento A, Viegas M, Galiano M, Videla C, Carballal G, Mistchenko AS, Melero JA. 2006. Natural history of human respiratory syncytial virus inferred from phylogenetic analysis of the attachment $(\mathrm{G})$ glycoprotein with a 60-nucleotide duplication. Journal of Virology 80(2):975-984.

190.Tsukagoshi H, Yokoi H, Kobayashi M, Kushibuchi I, Okamoto-Nakagawa R, Yoshida A, Morita Y, Noda M, Yamamoto N, Sugai K, Oishi K, Kozawa K, Kuroda M, Shirabe K, Kimura H. 2013. Genetic analysis of attachment glycoprotein (G) gene in new genotype ON1 of human respiratory syncytial virus detected in Japan. Microbiology and Immunology. Epub: June 11, 2013. doi: 10.1111/1348-0421.12075.

191.United Nations. 2012. The Millennium Development Goals report 2012. New York: United Nations. 1-68 p.

192.Valley-Omar Z, Muloiwa R, Hu N, Eley B, Hsiao N. 2013. Novel respiratory syncytial virus subtype ON1 among children, Cape Town, South Africa, 2012. Emerging Infectious Diseases 19(4):668-670.

193.van Niekerk S, Venter M. 2011. Replacement of previously circulating respiratory syncytial virus subtype B strains with the BA genotype in South Africa. Journal of Virology 85(17):8789-8797.

194.Venter M, Madhi SA, Tiemessen CT, Schoub BD. 2001. Genetic diversity and molecular epidemiology of respiratory syncytial virus over four consecutive seasons in South Africa: identification of new subgroup A and B genotypes. Journal of General Virology 82(9):2117-2124.

195. Ventre K, Randolph A. 2007. Ribavirin for respiratory syncytial virus infection of the lower respiratory tract in infants and young children. The Cochrane Database of Systematic Reviews 24(1):CD000181. 
196.von Linstow M, Eugen-Olsen J, Koch A, Winther T, Westh H, Hogh B. 2006. Excretion patterns of human metapneumovirus and respiratory syncytial virus among young children. European Journal of Medical Research 11(11):329-335.

197.Vos R, Vanaudenaerde BM, Verleden SE, De Vleeschauwer SI, Willems-Widyastuti A, van Raemdonck DE, Schoonis A, Nawrot TS, Dupont LJ, Verleden GM. 2011. A randomised controlled trial of azithromycin to prevent chronic rejection after lung transplantation. European Respiratory Journal 37(1):164-172.

198. Walsh EE, McConnochie KM, Long CE, Hall CB. 1997. Severity of respiratory syncytial virus infection is related to virus strain. Journal of Infectious Diseases 175(4):814-820.

199.Wang E, Law B, Stephens D. 1995. Pediatric Investigators Collaborative Network on Infections in Canada (PICNIC) prospective study of risk factors and outcomes in patients hospitalized with respiratory syncytial viral lower respiratory tract infection. The Journal of Pediatrics 126(2):212-219.

200.Wang L-F, Collins PL, Fouchier RAM, Kurath G, Lamb RA, Randall RE, Rima BK. 2012. Family Paramyxoviridae. In: King AMQ, Lefkowitz E, Adams MJ, Carstens EB, editors. Virus Taxonomy: Ninth Report of the International Committee on Taxonomy of Viruses. San Diego: Elsevier Academic Press. p 672-685.

201.Wennergren G, Kristjánsson S. 2001. Relationship between respiratory syncytial virus bronchiolitis and future obstructive airway diseases. European Respiratory Journal 18(6):1044-1058.

202. Wertheim JO, Worobey M. 2009. Relaxed selection and the evolution of RNA virus mucin-like pathogenicity factors. Journal of Virology 83(9):4690-4694.

203.Wertz GW, Collins PL, Huang Y, Gruber C, Levine S, Ball LA. 1985. Nucleotide sequence of the $G$ protein gene of human respiratory syncytial virus reveals an unusual type of viral membrane protein. Proceedings of the National Academy of Sciences 82(12):4075-4079.

204.World Health Organization. 2012. World health statistics 2012. Geneva: World Health Organization. 1-176 p.

205. White L, Waris M, Cane P, Nokes D, Medley G. 2005. The transmission dynamics of groups A and B human respiratory syncytial virus (hRSV) in England \& Wales and Finland: seasonality and cross-protection. Epidemiology and Infection 133(2):279-289.

206. Wright P, Cutts F. 2000. Generic protocol to examine the incidence of lower respiratory infection due to respiratory syncytial virus in children less than five years of age: field test version. Geneva: Department of Vaccines and Other Biologicals, World Health Organization. 1-34 p.

207. Yamaguchi M, Sano Y, Dapat IC, Saito R, Suzuki Y, Kumaki A, Shobugawa Y, Dapat C, Uchiyama M, Suzuki H. 2011. High frequency of repeated infections due to emerging genotypes of human respiratory syncytial viruses among children during eight successive epidemic seasons in Japan. Journal of Clinical Microbiology 49(3):1034-1040.

208. Yoshida A, Kiyota N, Kobayashi M, Nishimura K, Tsutsui R, Tsukagoshi H, Hirano E, Yamamoto N, Ryo A, Saitoh M, Harada S, Inoue O, Kozawa K, Tanaka R, Noda M, Okabe N, Tashiro M, Mizuta K, Kimura H. 2012. Molecular epidemiology of the attachment glycoprotein $(\mathrm{G})$ gene in respiratory syncytial virus in children with acute respiratory infection in Japan in 2009/2010. Journal of Medical Microbiology 61(6):820-829. 
209.Zamora MR, Budev M, Rolfe M, Gottlieb J, Humar A, DeVincenzo J, Vaishnaw A, Cehelsky J, Albert G, Nochur S, Gollob JA, Glanville AR. 2011. RNA interference therapy in lung transplant patients infected with respiratory syncytial virus. American Journal of Respiratory and Critical Care Medicine 183(4):531-538.

210.Zhang L, Mendoza-Sassi R, Wainwright C, Klassen T. 2008. Nebulized hypertonic saline solution for acute bronchiolitis in infants. The Cochrane Database of Systematic Reviews 8(4):CD006458.

211.Zhang R-F, Jin Y, Xie Z-P, Liu N, Yan K-L, Gao H-C, Song J-R, Yuan X-H, Xiao NG, Guo M-W, Zhou Q-H, Hou Y-D, Duan Z. 2010. Human respiratory syncytial virus in children with acute respiratory tract infections in China. Journal of Clinical Microbiology 48(11):4193-4199.

212.Zhang Z, Schwartz S, Wagner L, Miller W. 2000. A greedy algorithm for aligning DNA sequences. Journal of Computational Biology 7(1-2):203-2014.

213.Zlateva KT, Lemey P, Moës E, Vandamme A-M, van Ranst M. 2005. Genetic variability and molecular evolution of the human respiratory syncytial virus subgroup B attachment G protein. Journal of Virology 79(14):9157-9167.

214.Zlateva KT, Lemey P, Vandamme A-M, van Ranst M. 2004. Molecular evolution and circulation patterns of human respiratory syncytial virus subgroup A: positively selected sites in the attachment G glycoprotein. Journal of Virology 78(9):4675-4683.

215.Zlateva KT, van Ranst M. 2004. Detection of subgroup B respiratory syncytial virus in the cerebrospinal fluid of a patient with respiratory syncytial virus Pneumonia. The Pediatric Infectious Disease Journal 23(11):1065-1066.

216.Zlateva KT, Vijgen L, Dekeersmaeker N, Naranjo C, van Ranst M. 2007. Subgroup prevalence and genotype circulation patterns of human respiratory syncytial virus in Belgium during ten successive epidemic seasons. Journal of Clinical Microbiology 45(9):3022-3030. 


\section{PIELIKUMI}

Veidlapa Nr E-9 (2)

RSU ẼTIKAS KOMITEJAS LËMUMS

Rīga, Dzirciema iela 16, LV-1007

Tel.67409137

\begin{tabular}{cll}
\hline Komitejas sastāvs & Kvalifikācija & Nodarbošanās \\
\hline 1. Profesore Vija Sīle & Dr.phil. & filozofs \\
2. Asoc. prof. Voldemārs Arnis & Dr.biol. & rehabilitologs \\
3. Docente Santa Purvinaa & Dr.med. & farmakologs \\
4. Profesore Regīna Kleina & Dr.med. & patanatoms \\
5. Asoc. prof. Guntars Pupelis & Dr.med. & kirurgs \\
6. Asoc. prof. Egils Korṇevs & Dr.habil.med. & stomatologs
\end{tabular}

Pieteikuma iesniedzējs: Dr. habil.med. profesore Dace Gardovska

RSU Pediatrijas katedra

Pētījuma nosaukums: Bērniem nozīmīgo pneimovīrusu (RSV un hMPV) izraisītās dziḹas elpceḷu infekcijas, to klīniskais un molekulārais raksturojums terciārā līmeṇa hospitālī Latvijā.

Iesniegšanas datums: 03.03.2009.

Pētījuma protokols:

(X) Pētījuma veids: izmeklēšanas protokols, klīniskie un laboratoriskie izmeklējumi

(X) Pētījuma populācija: 2 - 24 mēnešus veci BKUS hospitalizēti bērni ar klīniskām akūtas dziḷo elpceḷu infekcijas pazīmēm (klepus, izmainīta auskultatīvā atradne, palielināts elpošanas darbs, apnojes lēkme), kas slimo mazāk par 10 dienām un ir bijuši iepriekš veseli.

(X) Informācija par pētījumu:

(X) Piekrišana dalībai pētījumā:

Citi dokumenti:

1. Vecāku piekrišanas formas paraugs

2. VSIA BKUS valdes priekšsēdētāja piekrišana pētịjuma veikšanai

Lēmums: piekrist biomedicīniskajam pētịjumam

Komitejas priekšsēdētāja vietniece Vija Sīle
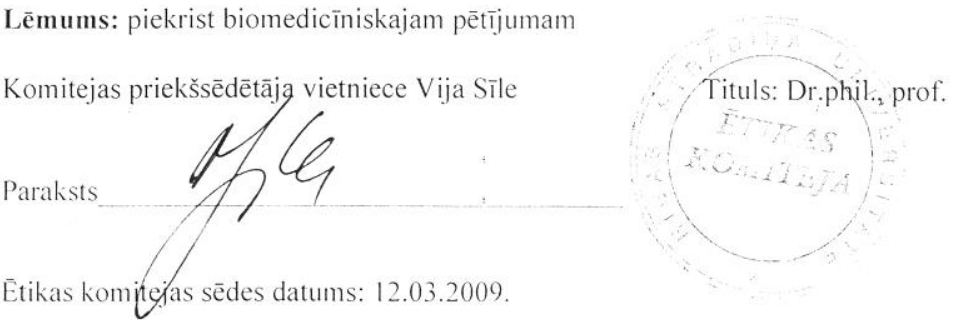

\section{1. pielikums. Rīgas Stradiṇa universitātes Ētikas komitejas aț̣auja veikt šo pētījumu.}

2009. gada 12. marta sēdes lēmuma kopija. 